



\section{Digitized by the Internet Archive in 2007 with funding from Microsoft Corporation}




wh. 


\section{By Guglielmo Ferrero}

The Greatness and Decline of Rome In Five Volumes

Vol. I.-The Empire Builders

Vol. II.-Julius Cæsar

Vol. III.-The Fall of an Aristocracy

Vol. IV.-Rome and Egypt

Vol. V.-The Republic of Augustus

Characters and Events in Roman History

From Cæsar to Nero (60 B.C. -70 A.D.)

Ancient Rome and Modern America

A Comparative Study of Morals and Manners

Between the Old World and the New

A Moral and Philosophical Contrast

A Short History of Rome

In Two Volumes

Problems of Peace in Europe 


\title{
Problems of Peace
}

From the Holy Alliance to the League of Nations. A Message from a

European Writer to Americans

\author{
By \\ Guglielmo Ferrero \\ Author of "A Short History of Rome," "The Greatness \\ and Decline of Rome," etc.
}

G. P. Putnam's Sons

New York and London

Tbe Iknickerbocker Dress

I9I9 


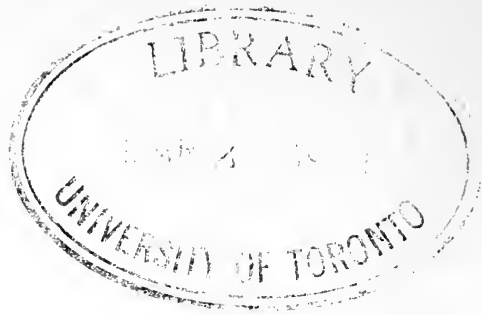

COPYRIGHT, I9I9

BY

GUGLIELMO FERRERO 


\section{CONTENTS}

CH APTER

PAGE

I.-To the American People . . I

II.-The French Revolution and the AUSTRIAN EMPIRE . . . . . 6

III.-The League and the Peace of the Dynasties (I8I5-I848) . . . 29

IV.-The Revolution of 1848 . . . 65

V.-The Great Surprise. The Germanic TRIUMPH (I848-I870) . . . 106

VI.-The German Peace and the GerMANIZATION OF EUROPE (1870-1914) · 165

VII.-From the Holy Alliance to the League of Nations . . . 240 



\section{Problems of Peace}

\section{CHAPTER I}

TO THE AMERICAN PEOPLE

"WILL they come or will they not?" That was the question which the combatants on either side put to each other as they looked anxiously towards the West. At first the horizon was calm and clear; then far off appeared a tiny cloud of dust in the midst of which there could just be descried a flag or two, and here and there the glitter of a weapon. But the cloud broadened and ascended, tumultuous with men and coruscating with steel, and then, at last, there issued from its mighty depths, friend and foe; those who exult and those who tremble, beheld a people in arms-an inexhaustible flood, a final reserve, which came in time to decide the issue of the mightiest and bloodiest conflict ever waged by mankind.

To us it seems a dream. Can the prodigy have 
really come to pass? Can it really be that the United States in its turn precipitated itself into the struggle of the nations? And my thoughts go back ten years to the long conversations I had towards the end of 1908 at the White House with Theodore Roosevelt, and in so many other hospitable houses in Washington, from that of Baron Mayor des Planches to that of Elihu Root, with the men who were at that time governing the great Republic, to other conversations in New York, Boston, Philadelphia, in Pittsburg, and in distant Chicago, with authors and bankers, merchants and professors, journalists and ministers of every religion and creed. How often in the course of such conversations have I not heard Americans of every position and status express, each in his own way, his admiration for European culture, for its schools, its art, its science, its monuments, and its history. With very few exceptions, however, Americans, while admiring the greatness of Europe, seemed to wish to keep out of our wars and our revolutions, to observe these indeed, but from a great distance by means of powerful telescopes, as one would examine a cosmic catastrophe on another planet. Their attitude, if not calmly indifferent, resembled the sad serenity with which we contemplate the cataclysms of 


\section{To the American People}

Nature. And, as every passion which we do not feel or understand seems foolish or even positively insane, this neutrality of view in the case of many Americans verged on the ironic compassion with which we smile at a revolution in China, a conspiracy in Turkey, a pronunciamento in South America, or, in short, at any convulsion the motives of which we do not comprehend. Therefore I often asked myself whether America could ever acquire the melancholy understanding of our implacable hatreds, could ever grasp the meaning of the death struggle between France and Germany, the persecution of which the Catholic Church has been in turn the author and the victim, the revolutionary strivings in the Russian Empire which resemble the sulphurous emanations and intermittent rumblings of a volcano half asleep, the bitter internal discords in France which die down only to revive again, or the hideous death agonies of the Hapsburgs.

In those days any man who dared to predict that nine years later the United States would rush, sword in hand, into the mêlée of European antagonisms, now at last facing each other in a mortal battle, would have appeared to me as to everyone else to be a visionary. And yet this impossibility has become a fact. America has been fighting 
in the heart of Europe with all her strength, for life or death. America placed her still intact resources on the side of France, England, Italy, Belgium, Serbia, Portugal, and Montenegro, all of which were in peril after the collapse of Russia. The issue, we may safely say, was one on which the course of history for centuries would depend. That is why a European who has already had so many occasions to be grateful for American kindness and courtesy, who has had the good fortune to mature his mind in America for the understanding of these terrible events, begs leave to recall briefly to Americans the whole stormy history, which has now reached its climax, from its beginnings in the French Revolution, rapidly reviewing it as it grew decade by decade, until it suddenly precipitated itself like a mighty cataract into the immeasurable maelstrom of the present crisis. Rapidly retracing its course from its beginnings to the edge of the rapids, we shall be able to see how far we must go back to find a landing-place where we may unload from the imperilled vessel of Western Civilization the most precious part of what we have inherited from our forefathers and, while we abandon the battered hull to the torrent and the abyss, decide to what point below the fall we may safely carry what remains of our possessions in order to 


\section{To the American People}

embark them on a quieter and more friendly stream. Only if we know how this tragedy has been slowly maturing for more than a century shall we-the men of the old and the new worlds now united in the brotherhood of a common danger and a common duty-be able to understand what we must attempt together in order that all future generations may be spared the horrors which fate has imposed on us. 


\section{CHAPTER II}

THE FRENCH REVOLUTION AND THE AUSTRIAN EMPIRE

THE question whether the French Revolution gave liberty to the world has been bitterly debated for more than a hundred years. Some say it did, others that it did not. In order to decide the point it would be necessary to know what each side means by liberty. But at any rate there is no doubt whatever that one of the first gifts generously bestowed by that Revolution on the peoples was that of compulsory military service.

This point is of such capital importance that we must stop to consider it for a moment. It must at once be admitted that any military system must be based on one of two contrary principles-the professional principle, whereby war is regarded as one among other arts practised by mankind, a pursuit voluntarily chosen as a means of livelihood by any one who feels he has a vocation for it, or the political principle, which regards the bearing of arms as a civic duty incumbent on all male persons 


\section{The French Revolution and Austria 7}

whatever their profession, their social position, or their education. Each of these principles has its good and its bad side. The professional principle is best for those States which require only a small army but which must have it of the best quality, because men who have the vocation of arms are few. The political principle, on the other hand, is well suited to States which need a larger force of less high quality and not trained above the average. But it is clear that, of the two, the professional principle is the more in conformity with human nature and military science, while the political principle is not and cannot be more than a desperate expedient for increasing numbers. There is no art which, if it is to be thoroughly known and skilfully exercised, does not require aptitude, close study, and long practice and, if this is so, how can it reasonably be argued that we can all of us become improvised warriors in a few months? For war is one of the most difficult of all arts, requiring as it does, not only much knowledge but a stern apprenticeship in such very arduous virtues as obedience, courage, and patience. This is why all nations have abhorred conscription as the most detestable of servitudes, and why it has always been difficult to induce them to submit to it. In the sixteenth and seventeenth centuries war was the chief occu- 
pation of the Courts of Europe, and yet none (though all were absolute monarchies) had the courage or the power to impose on all its own subjects the obligation to serve in its armies. The soldiers who served under their banners were not all volunteers, and they did not scruple to enlist soldiers by force when they could. But this was the exception, not the rule, and the men taken were of the humblest class, picked up here and there, over a long period of time. These forced soldiers in the sixteenth and seventeenth centuries were not citizens fulfilling a civic duty equally obligatory on all, but men compelled by their own exceptional ill luck to adopt the profession of arms. In any case, if volunteers were not numerous these impressed soldiers were even less so; consequently, armies were small and the wars whereby the Courts strove to realize their territorial ambitions were limited not only by their poverty but by the difficulty, not a small one, of finding soldiers.

How was it then that the French Revolution, which was to free the world, brought with it this new servitude side by side with the Declaration of the Rights of Man? The governments of Europe during the seventeenth and eighteenth centuries were at the same time both strong and weak. They were strong because they were legitimate, because 
they possessed a title to authority which all men recognized as genuine. These titles varied from State to State and were sometimes even contradictory. In some cases, such as, for example, the Kingdom of Poland and many small Republics and in the leading case of the Holy Roman Empire of the German Nation, the title was given by election. In other States it rested on hereditary right, on treaties, or on the complicated principles and elaborate rules of feudal law. In some regions the traveller passed under a new sovereign every few miles of his journey; sometimes sovereignties were enclosed, one within another, without any regard to geography, to commercial interest, or to that uniformity and equality which now seem to us to be a necessary condition of order. But logical or illogical, just or unjust, decrepit or still vigorous and fresh, all these sovereignties appeared hegitimate, not because all men venerated them as such in their hearts, but because everybody respected, or said they respected, them, and because no one dared to interfere. All being supported by many interests, all maintained themselves intact in the respect of the peoples, precisely because there were so many of them, and because there was none among them so strong as to be able to overthrow and destroy all the rest. But these governments, 
so 'strong in the possession of their authority, were extremely weak in exercising it. Instead of being gathered up in a few vigorous, well co-ordinated and subordinated organs of government, authority was scattered among a great number of different centres, ill co-ordinated and subordinated, each jealous of its own rights and privileges.

Moreover the authority of the State was not mereiy scattered through a multitude of organs, it was also limited in every direction by acquired privilege, by tradition, by local autonomies and customs, and therefore it was forced to take a slow, difficult, and devious way among all these obstacles and impediments, like a river at the bottom of a narrow gorge twisted and obstructed at every turn by enormous boulders. Who, for instance, would believe that in 1806, when Revolution and War had already half uprooted the old order with its pedantic respect for legality, in the night of October IIth-I2th on the eve of the Battle of Jena, the Prussian army encamped in the woods suffered severely from the cold because, not being in enemy territory, it had not the right to requisition even what was necessary for its support; that the horses went without fodder, though there were ample supplies in Jena afterwards taken by the French, because Wolfgang von Goethe, the Grand Ducal 
The French Revolution and Austria II

Commissariat Officer, did not inform the generals in time that they had his permission to take what was necessary!

Throughout the eighteenth century there continued to exist a curious monument of solemn and venerated impotence in the shape of the Holy Roman Empire of the German Nation. The diadem which the electing Princes had the right to bestow on the object of their choice was the most august emblem of authority before which the West could bow, for it was believed to be that which had been worn by the Roman Emperors. But, though the name survived, the substance of the Empire had in the course of centuries been shattered into a cloud of small and even tiny States. How many were the families and ecclesiastical authorities who possessed sovereign rights and powers during the eighteenth century in the German Empire with the titles of Duke, Prince, Count, or Knight of the Empire? Nearly fifteen hundred, of which the Knights of the Empire accounted for a thousand by themselves! Now these families and these Prelates not only possessed sovereign rights each within his own little territory, and each different from the rest, which the Emperor was obliged to respect. All but the Knights had also the right to legislate, in some cases voting singly, in 
others collectively, at the Diet of Ratisbon, which was composed of three Chambers-Electors, Princes, and Imperial Cities. On his side, the Emperor, who for three centuries had always been a Hapsburg, had to govern his own States in addition to the Empire. Thus there was a Holy Roman Empire which, as it were, hired the sovereign of another State to be its Emperor, which shared the capital, Vienna, of this State, which was governed by more than a thousand sovereigns, each having his own territory and his own laws, and a number of whom, meeting at the Diet of Ratisbon, made laws for all the Empire, thus doubly limiting the power of the Emperor. It may easily be imagined how rapid and how vigorous in action a government so constituted was likely to be. Yet it was so venerable in its antiquity, and the legitimacy of so many authorities, laws, and traditions was so indisputable that for more than a century, from the Thirty Years' War till the Revolution, it had succeeded in protecting a great number of helpless little States against the ambitions of Austria and Prussia, and in restraining the turbulent nature of the German peoples by the invisible network of its many legalities, which were so pedantically observed.

But the eighteenth century was weary of obey- 
The French Revolution and Austria 13

ing these governments which it still revered, for they were weak, incapable, and often unjust and oppressive, not because they were tyrannous in intention but because they were impotent. This is the contradiction in the work of that century, frivolous and tragic, trifling and powerful, little and great, which, when it felt that old age was creeping upon it determined to have its youth again even at the cost of selling its soul to the Devil. More than two hundred years previously, human reason, deserting the mediæval schools, had ventured forth into the infinite, seeking truth no longer in the pages of a few books but in the affairs of real life. The art of war had been reborn in Europe and had emerged with the learning of the ancients from the oblivion of the Middle Ages. The principles of strategy and tactics were rediscovered in Greek and Latin books, and men worked out their application to the use of firearms then recently invented. Among the greater and lesser European dynasties had arisen a struggle to aggrandize themselves either by force of arms or by treaties, not in Europe only but also in Asia and Africa, and in America, the newly discovered continent. The wars of Religion which sprang from the Reformation, had supervened, and were often mixed up with wars of dynastic predominance 
and colonial conquest. Thus for two centuries what we now call militarism had been making great strides in Europe. Diplomatic skill, valour in war, success in negotiation and in fighting, were passports to the favour of the great Territorial aggrandizements and were valued almost in proportion to the efforts and the sacrifices they had cost. But armies required money, and war not money only but promptitude, vigour, and elasticity of organization in the belligerent States. Hence, in the eighteenth century, the dispersion of authority, the scrupulous respect for vested rights and for tradition characteristic of the old régime became specially obnoxious to the Courts engaged in these wars and conflicts, when they found that they were thereby weakened and embarrassed. This was the cause of the intellectual ferment and the mania for action and for novelty which agitated the upper classes of the greater European States at this time, driving them to seek sources of riches, beauty, and truth which had hitherto been unknown. In France, the human mind made a heroic effort to remove the source of authority from parchments, from historic rights, from the inscrutable depths of divinity, into the sphere of human beings who were recognized as having the right to sit in judgment on governments and 
The French Revolution and Austria I5

therefore to accept a good government as a legitimate government. Germany, chained to the earth by the institutions of the Empire, took refuge in a paradise of the imagination, tried by means of romanticism to bring about a revolution in the realm of beauty by overthrowing classical models, and began to be fevered with that philosophic delirium which, growing with the disorder of the times, infected the whole of Europe in the ensuing century. England emulated the mythical achievement of Prometheus by creating docile, powerful, and unwearied slaves of iron animated by fire, by whose aid she might conquer the riches of the world. Every now and then Europe was startled by some portent which broke the ordinary course of human history. Now it was Frederick the Great who renewed the art of war; now Joseph the Second who desired to reform his empire from top to bottom; now the first partition of Poland. For the first time, three States came to an agreement to fall upon a weaker neighbour for no other reason than that they coveted her fertile lands, thus cancelling all the principles of international law as then acknowledged and putting in their place the right of force. There was immense fear and indignation in Europe at this event, but no less was the envy of all the States who might have 
wished, but could not or did not dare, to follow this disastrous precedent.

The élite of the eighteenth century longed, in a word, for governments stronger, more alert, and more intelligent than those by which Europe was then ruled, even if they should possess fewer antique parchment credentials, if only they were ready to provide capacity and energy in the place of the legitimacy which seemed to have no life left in it. For this reason, encouraged by sovereigns and powerful personages, they were ready to assail the existing order, or at least such parts of that order as seemed most out of date and most insensible to the aspirations of the day. There is, however, nothing on earth, which is at the same time more stable and more fragile than a legal principle. It will resist for centuries all the criticisms of reason, all the protests of sentiment, and all the assaults of opposed interests, only to fall in a few weeks when overwhelmed by a war or a revolution. On this occasion also, the earthquake of the Revolution overthrew in a few years what the criticism of philosophers and the reforms of princes had barely shaken. After hesitating between several aims, the Revolution, attacked on all sides and on the point of being overwhelmed by numbers, had recourse to the political principle of 


\section{The French Revolution and Austria 17}

military service. Owing to the desperate necessity of finding soldiers, soldiers, and yet more soldiers, it assembled its youthful levies under officers and non-commissioned officers, who had served the Monarchy, inflamed them with a passion of patriotism and revolutionary ardour, squandered their blood without stinting, unreservedly adopted the principle, never fully accepted by the eighteenth century, that war annuls all rights which are in force in time of peace, and conquered a Europe which depended on little armies recruited on the professional principle.

But for success in war, valorous and well-led armies are not enough. Resolute and energetic governments are also necessary; and so the Revolution had to set about creating in France a powerful State, based on the ruins of the ancient principles of legitimacy and its own dreams of happiness and freedom. The Church and the Nobility, the two powers which under the ancien régime had overpowered the Monarchy they pretended to serve, were humiliated. Authority was concentrated in the State which received welldefined powers and was administered by a capable staff recruited according to merit. Wide roads of common law convenient to all were driven through the tangled thickets of privilege and vested rights 
which had burdened so much of the old France. The medley of the ancient laws was codified and made simple. In short, there was improvised a simpler and stronger government, more efficient, and more in harmony with the dictates of reason, which plunged boldly with fresh forces into the struggle for territorial expansion, making a free and ever more audacious use of the sovereign right of force which, to the great scandal of all Europe, Russia, Prussia, and Austria had, for the first time, applied to Poland.

The Revolution did not, however, succeed in finding or applying any new principle of legitimacy. For a time, some attempt was made to rediscover the mystic source of lawful authority in the will of the people; but as no one knew exactly where this will was to be found or how it was to be expressed or recognized, it was finally confounded and identified with the genius, the energy, the fortunes, and the victories of a single man. The Republic was, practically without intermission, governed by a dictatorship until an ex-captain of artillery, born of a needy family of the minor nobility of Corsica, ascended the throne of France because he had proved that he knew how to rule and make war, and became the first champion of the new Divine 
The French Revolution and Austria I9

Right of intelligence which was apparently imposing itself upon Europe.

Thus the French Revolution became at once the terror and the model of European monarchies, by which it was the more hated the more they were obliged to learn from it. Among all the rest, the two great Germanic monarchies, Austria and Prussia, were its best scholars and its most implacable enemies. This contradiction contains one of the two most profound and terrible secrets of the history of Europe in the nineteenth century. Taught by their imitation and by their defeats, Austria and Prussia sought to strengthen themselves as France had done by taking advantage of the upheaval which had weakened in every mind the sentiments of legality and tradition, and the respect for treaties and for the established order. In 1793 and 1795, while at war with France, Austria and Prussia, profiting by the difficulties with which their adversary was struggling, agreed with Russia to seize the Polish territories which had escaped the first partition. Austria began to introduce conscription, though to a less degree than in France, and, in 1797, under the Treaty of Campo Formio, she came to an understanding with the French Republic to which she surrendered Belgium, Lombardy, and the eastern bank of 
the Rhine, receiving in exchange the territories of the Venetian Republic. The young Republic, the daughter of the Revolution, and the Holy Roman Empire agreed to tear up parchments and scraps of paper in order to aggrandize themselves at the expense of old and legitimate governments, among which was no other than the Republic of Venice, the most brilliant jewel among Mediæval and Renaissance States, a miracle of well-preserved beauty. Henceforth, no legitimate government which could not defend itself was recognized as possessing any rights at all. As Napoleon said to Martens, International Law was the same thing as the law of the stronger. Ambition and suspicion were now sufficient motives for war; the international order ceased to be stable, and, as no State was safe, all had to arm themselves. There was terror at the French victories and at the ever imminent danger of war. An even greater terror of the catastrophe which had destroyed the French nobility and the Monarchy was inspired in Austria, Prussia, and the lesser German States, where the aristocracy, the clergy, the army, and the official class rallied to the support of legitimate monarchy against the upstart power of France and the dragon of Revolution. They made a willing sacrifice of vested right, tradition, and all privileges which 
The French Revolution and Austria 2I

limited or hindered, even to their advantage, the authority of the King. At Vienna, centralized absolutism, which had been fighting tenaciously for two hundred years against the spirit of autonomy, rapidly prevailed. Resistance weakened; the provincial Diets gave up contending for their constitutional rights. Germany began to awaken from her long sleep, her philosophic delirium increased as the old world fell to pieces around her; behind Kant stood Fichte and Schelling. Even the lesser Princes felt and admitted that the day was at hand when they would have to be merged and disappear in a higher and more powerful unity. In all the monarchical States, the authority of the Court increased because the Court, following the example set in France, now watched over and directed everything. But the more the legitimate monarchies, as their power grew, imitated Napoleon, the more they hated the usurper and the more they longed to overthrow him. Hence one war sprang from another in a concatenation which seemed as if it would never end, and, with each new war, there crumbled away some new part of the ancient order under which Europe had lived. In 1801, the Treaty of Lunéville surrendered the whole of the left bank of the Rhine to the French Republic. In the following year the stronger States of Ger- 
many-Prussia and Austria among them-compensated themselves for this loss by agreeing to the immediate annexation of a great number of the smaller States, for the most part Free Cities and ecclesiastical Principalities. In 1804 , while the war against France and the Third Coalition were being prepared, Napoleon crowned himself Emperor, and Francis I. at once followed suit by proclaiming himself Emperor of Austria "with all due regard to the independent States." This double status did not last long, for in I806, after the Battle of Austerlitz, the discomfiture of the Third Coalition, and the Peace of Presburg, Napoleon united Western and Southern Germany, including Bavaria, in the Confederation of the Rhine which was placed under his protection, and, on August 6th, Francis I. declared that the Holy Roman Empire of the German Nation was dissolved. Destiny was fulfilled. Henceforth the German people was freed from the system of little Kingdoms, respected but impotent, under which it had become feeble. The littleGerman principalities which had escaped from the ruin of 1802 were now incorporated in a few more powerful States. Germany had taken another step towards her unification, and in her midst there arose the new Empire of Austria, imitating but hating the French Empire. 
The French Revolution and Austria 23

It is very frequently said that the Empire of Austria is a relic of the Middle Ages, a feudal State, and a living anachronism. This is only partly true. The Austrian Empire would be younger by a few months than the Empire of the Napoleonidæ, if the latter had not been shattered by Fate in its earliest years. She also is a daughter, albeit a bastard daughter, of the French Revolution, one of the States which, like Prussia, profited by the ideas, the innovations, and the institutions that the Revolution and the Empire created or experimented with, not in order to alter the principles of government or to liberate the world, but to aggrandize themselves, to increase their military power, and to free themselves from many of the impediments from which, under the ancient régime, owing to the dispersion and the limitation of its authority, the State suffered.

After her defeat at Jena, Prussia followed this path even more ardently than Austria. The State was modernized by the addition of all the institutions and all the principles of the Revolution which could reinforce the authority of the monarch, the government, and the nobility. The principle of compulsory military service for all citizens was definitely adopted, and applied more resolutely and coherently than in all other countries, not 
excepting France. But the sole object was to be able to fight with better fortune the hated master who had taught them how to become strong at the expense of their own principles of legitimacy. The fact is that these ancient States were afraid of being rejuvenated by dealing with the Devil, who had taken the form of the Revolution, and their fears were not without foundation, for how can an established order of things be founded on the mere prestige of force, which is the most unstable of all elements in human life?

Even Napoleon tried to legitimatize his authority by means of ancient parchments which had escaped the furnace of the Revolution. He caused himself to be crowned, and insisted at all costs on allying himself with the ancient dynasties of Europe. How should these ancient dynasties not have been terrified by the danger with which ideas and events in France threatened their immemorial authority even in the very hour of the increase of their strength? And how was the prestige of the old crowns to be restored; how were they to recover their old symbolic lustre before they had destroyed this false crown that a soldier of genius had made with his own hands before their very eyes and which in the eyes of so many shone with a glory greater than their own? 
The French Revolution and Austria 25

Hence there flared up in Europe a war which became more bitter every year, and which, like our present war, seemed as if it would never end. When it died away in one country it was rekindled in another, because there could be no confidence and therefore no solid agreement but merely a truce between the old dynasties and aristocracies of Europe and the new order of things as constituted in France.

In the midst of these wars, amid the clash of arms, the German tribes at last reawakened and took part in the great struggle-no longer with their pens, their dreams, and their philosophies, but by hurling themselves into the final duel between Europe and the French Empire. In the end, aided by England and the mistakes of the enemy, the ancient dynasties of Europe vanquished their model and the French Empire fell. But the victors understood that, having squandered the blood of the peoples in order to overthrow Napoleon, they would have to give peace and order to their subjects, who were exhausted by the interminable war, if they were to re-establish their own authority. They knew that they could not do this or maintain peace by force alone, without recourse to some of the principles of legitimacy which had been confused and ruined not only by 
the Revolution but also by some of the counterrevolutionaries. The fall of Napoleon had shown the world how weak were the governments created by the Revolution and the Empire. They were vigorous and enterprising, but they were the children of their own efforts and lacked all historic title, and all of them, including the Kingdom of Italy, fell before the first breath of misfortune.

In Italy, the people had reproached its strong and laborious government with the very benefits it conferred as if these had been crimes. Order, public works, the increase of industry and agriculture, became odious by reason of the burdens by which these benefits had to be paid-levies, taxes, and a strict administration. The Minister Prina was assassinated, and in him perished the precursor of the line of vigorous and intelligent administrators who, half a century later, were to organize the new Kingdom of Italy. The government, whose sole title was that it was more efficient than its predecessors, was overturned. It is the eternal inconstancy of peoples that when they have a weak government they sigh for the severe discipline of force, and, when they have to obey in earnest, they look back with longing to the slack control of decrepit rulers.

But what was to be the new principle of au- 
The French Revolution and Austria 27

thority? The Wars of the Revolution and the Empire had reinforced in the Great States of Europe the power and the prestige of Courts, and the victors believed that they had found what was required in the Divine Right of the historic dynasties, in which they acclaimed not ONE principle but THE sole and single principle par excellence of all legitimacy. Metternich defined it in his celebrated dictum - "Only sovereigns have the right to direct the fate of peoples and for their veto they are responsible only to God." The old crowns and sceptres were drawn from the repositories in which they had been timorously hidden when the Revolution had brutally thrown into the gutter the sceptre and the crown of the most ancient dynasty in Europe. They were dusted and polished so as to restore as far as might be their former splendour. The people were directed once more to bow before these ancient emblems of authority and these alone, and the victors, as if they were carrying out a duty laid upon them by God, proceeded to divide the rich booty which, when France had been driven back to the frontiers of $\mathbf{1 7 8 9}$, comprised the Belgian, Dutch, Swiss, and German Departments; the Kingdom of Italy; the Duchies of Lucca and Piombino; the Illyrian provinces; Saxony, Westphalia, and the territories of the Con- 
federation; the Duchy of Warsaw-in all, thirtytwo million souls, whom the powers divided among themselves like a herd of cattle. The Austrian Empire received Lombardy, Venetia, the Illyrian provinces, and the Presidency of the Germanic Confederation. Piedmont and Sardinia were restored to their former sovereigns with the addition of the territory of the ancient Republic of Genoa. The Bourbons resumed possession of the Kingdom of Naples and the Pope that of the States of the Church. Belgium and Holland were reunited and assigned to the House of Orange. The territories on the left bank of the Rhine were divided between Prussia and Bavaria. Prussia received in addition a portion of Saxony, Russia the greater part of the Duchy of Warsaw. The King of Prussia and the Emperors of Russia and Austria thereupon concluded among themselves the compact known as the Holy Alliance. 


\section{CHAPTER III}

THE LEAGUE AND THE PEACE OF THE DYNASTIES I $815-1848$

By concluding and accepting the compact of the Holy Alliance, the monarchies of Europe renounced the policy of continuous war whereby they had tried to aggrandize themselves during the seventeenth and eighteenth centuries. They sheathed their swords; they took an olive branch in their hands and pledged themselves to make war no more, to secure for their peoples the supreme benefit of a lasting peace, and to live as one great and united family. To an immense war, which had often seemed as if it could have no end, there succeeded a universal repentance whereby were chained up all the passions generated by warfare. From I8I 5 until 1848 the Courts of Europe were able to restrain their rivalries, their cupidities, and their ambitions sufficiently to prevent a breach of the peace. Their armies vegetated and slumbered, and military expenditure did not increase. The 
Holy Alliance, therefore, was the first essay at a league of European States attempted by the monarchies in order to maintain peace throughout the Continent. It was, however, a painful effort, imperfect in itself and destined, after thirty-three years, to a resounding collapse for reasons which I will now try to explain.

The Revolution and the Empire had created in the Valley of the Po a national State which might have lived and grown. If the Congress of Vienna, while changing the dynasty, had respected the Kingdom of Italy and had completed the work left half done by France by unifying the Valley of the Po from the Alps to the Adriatic, Italy, under the predominant authority of this national State, might have moved resolutely with the times, might have federated, unified, industrialized herself and modernized her institutions, manners, and doctrines by her own strength without setting three great Powers at variance, and, perhaps, without engaging in a fierce struggle with the Papacy. But the Fates ordained otherwise. Piedmont having been restored to the old dynasty, and Lombardy and Venetia assigned to the Hapsburgs, the new Austrian Empire dominated the whole peninsula from the Valley of the Po and held the hegemony of Italy because even the strongest of 
the Italian States, the Kingdoms of Sardinia and of the two Sicilies, were pigmies in comparison with the Austrian dominion, irrespective of the Duchies of Parma, Modena, and Tuscany, and the States of the Church. Now, if the Governments set up by Napoleon in the Valley of the Po lacked legitimate titles, the Empire of Austria was no better provided, the Congress of Vienna having audaciously usurped the function of Chancellor of the Most High for the political affairs of this imperfect world. The difficulty, moreover, was not confined to the policy for Italy but was common in a greater or less degree to all the States, old and new, of the so-called Restoration. The Divine Right of dynasties was a principle of the old legitimacy; but in the previous centuries it had not been the only one, for there were others, such as election, representation, heredity, treaties, tradition, etc., which were interlaced in the solid structures of political and social order. Even in the pre-revolutionary States of the House of Austria, Bohemia and Hungary had regarded themselves as elective monarchies. When all the principles of legitimacy were reduced to that of the new Divine Right of dynasties, all Europe and many of the States of Austria went back from the eighteenth to the fourth century, to the absolutism 
of Diocletian and Constantine-a leap backwards which was too sudden and violent for the century that had seen the fabulous adventure of the Revolution. Moreover the Austrian Empire, which wished to see all the peoples of Europe on their knees before the thrones of the restored sovereigns, forgot that it had taken advantage of the wars of the Revolution to steal the territories of others, and for the benefit of its own dynasty to dispossess legitimate governments. The Empire forgot that the new legitimacy had been improvised to cover the violence which it had used to so many legitimate governments within and without its borders. Why should the Bohemians and the Hungarians suddenly acquire the conviction that God had created them to obey the Hapsburgs when they had always believed that they had voluntarily placed themselves under the rule of that family? Why should the minor states of Italy recognize the divine mission of the Austrian Empire to protect and rule them, and why should the Venetians revere the Austrian Emperor and the Genoese the King of Sardinia as sovereigns sent to them from on high? The legitimate Governments of Venice and of Genoa should of course have been the ancient Republics now buried under the débris of the revolutionary earthquake. Similarly, 
if part of France recognized in Louis XVIII. a legitimate sovereign who had reascended the throne of his ancestors, the other part which believed in the Revolution and had prostrated itself before the domination of Napoleon, despised and hated the King as a usurper imposed upon them by foreign armies. The same disillusion awaited the King of Sardinia, the King of the two Sicilies, and the Pope; for, while one section of the population joyfully welcomed these rulers as legitimate sovereigns, another, though no doubt a minority, shut themselves up in their houses and cursed the return of the restored.

The Restoration in fact was the counterpart of the Revolution, even in the fact that its sole authentic title to authority was force. The Congress of Vienna had carried out its grotesque restoration of Europe, not because it had received a mystic mandate from heaven, but because the Allies had beaten Napoleon in 1814 and in 1815 , and had forced him to abdicate. This time, however, the right of force, which drew its strength from Napoleon's ruin, tried to surround itself with a veil of divine mystery -an adroit subterfuge invented by that veteran of the Chancelleries, Talleyrand. It might have succeeded if the cloud had still glittered in the full splendour of day, 
dazzling all men's eyes. But it was now grey with the slow twilight of a mysticism that was dying in men's hearts and that manifested itself only in fine words. It was now too much the custom to deal directly and confidently with God, and Europe could not be expected to tremble when its monarchs spoke loudly in His name. The monarchs themselves showed that they had little confidence that it would be so when, with a singular contradiction, they made more or less ambiguous promises of granting constitutions. The obligation to do so was inscribed in the compact of the Germanic Confederation, and the Bourbons themselves had to promise the Holy Alliance that they would establish a constitution and give to their kingdom representative institutions. Their allies felt sure that, notwithstanding the authenticity of the Bourbons' title to sovereignty, France would not for a single day have tolerated their absolute rule. But, though as a compensation for her lost empire, France was granted representative government, the other peoples were all cheated, except only some of the minor members of the Germanic Confederation. Even Prussia had to rest content with the modest Provincial Diets which were set up instead of a parliament. France having been chained up, the absolutist 
party prevailed practically all over Europe under the example and the authority of the Courts of Vienna and St. Petersburg, and with that party triumphed the old nobility, the younger daughter, as it were, of legitimacy, which everywhere seized the monopoly of all the high offices of State. The aristocrats were now deprived of the last traces of their sovereign rights, but they were at the same time freed from many obligations towards the mass of the people and the middle class. In. most of the Courts they became the domestic servants of the new absolutism for fear of the Revolution and the levelling laws which they had banished from the world. The consequence was that among the educated middle class throughout Europe there immediately began a growth of parties, secret societies, schools of art and philosophy, literary and intellectual groups, which openly or covertly aimed at discrediting as without warrant the Divine Right of Kings, aristocratic government, and the whole order of things as constituted by the Congress of Vienna, and which dreamed of nothing less than freeing the Revolution from the fetters imposed upon it by the Restoration.

It was in I82I and in Italy that the Revolution made its first renewed attempt. Not six years from the day on which he had resumed possession 
of his States with the declared intention of recommencing where he had left off on going into exile, Victor Emmanuel I., was compelled to abdicate by a revolutionary movement, the purpose of which was to demand a constitution. Unwilling to yield, or to summon Austrian assistance, and not having the courage to repress the Revolution which was favoured by part of his troops, he preferred to hand over his crown and sceptre to his brother, Charles Felix. An instant's hesitation on the part of the army had sufficed to make this Ruler, whom the Congress of Vienna had recognized as indefeasibly legitimate, lose heart and feel his authority vanish. It was a clear proof that the sole title of authority to rule was force. In the same year broke out the first disturbances in the Balkans, and Greece rose against the domination of the Turks. It is well to observe at this point how every great crisis in the Italian question has had its corresponding movement or tumult, either in Poland or in the Balkans, as if these three afflicted and diseased parts of the continent were connected by some link of inward sympathy. In this first period of European conflict, Greece was more fortunate than Italy. In spite of Austrian intrigue, the Powers, particularly Russia, which, in order to secure a pretext for continuing the war 
against Turkey and for continuing to expand at the expense of the Turk, secretly fomented the resistance of the Balkan peoples to the Sultan, intervened on behalf of Greece. Thus it happened that Greece, though vanquished by the Turks, did not rebel in vain, for when she was on the point of being annihilated by her powerful adversary, she was saved by the Powers. In 1827, the British, French, and Russian fleets destroyed the Turkish fleet at Navarino. In 1828 , Russia declared war on Turkey, and in the following year forced the Sultan to sue for peace. In 1830, Europe established the new Kingdom of Greece with a German dynasty under the protection of Russia, England, and France, and recognized the Principality of Serbia under the high patronage of Turkey.

Italy had no such good fortune. Charles Felix subdued the Revolution and a civil war began which was destined to last till 1859 . Dismayed by this first awakening of the revolutionary spirit, and stimulated by fear, the Italian governments, which, notwithstanding the false patents of Divine Right given them by the Congress of Vienna, felt that their authority was insecure, raged furiously against everything which savoured of "liberation" or "novelty," which reminded them of the Revolution or the Empire, not only in France, but also in 
England and Germany, or which, in the slightest degree departed from the official views of politics, religion, or literature. They disdained no weapon, no means of coercion, no instrument of torture. They used terrorism, corruption, the censorship, espionage, the state of siege, the confessional, the schools, the police, and the army, and for the ultimate crisis, Austrian regiments were kept ready near the frontier. The persecution was so savage and so implacable, that the new spirit was forced to hide itself. But it did not die. On the contrary, in silence and obscurity, in danger, in secret, in sorrow, it became strong and concentrated, and gradually permeated with invincible tenacity, the educated bourgeoisie and the better part of the nobility. Liberty, representative government, abolition of aristocratic and ecclesiastical privilege, the independence and unity of the nation became the more passionately desired objects of the better part of the people, the more the Austrian Empire and its client governments in Italy strove to check their longings.

But suspicion and terror, if they could not crush the new spirit, ruined the soul of the nation. Fidelity to the régime became the principal merit and the sole title to the benevolence of those in power. Therefore in all public offices, in the police, 


\section{The League of the Dynasties}

the army, the universities, and in the administration of the country, the first place was taken by men who were incompetent, perverse, and corrupt, but who were zealous defenders of the existing order against all its enemies, open or concealed, real or imaginary. Rectitude, seriousness, public spirit, independence of character, all the virtues which could not bow to tyranny, which despised the unjust threats of power, and resisted the insidious temptations of corruption were despised and suspected. How could it be hoped that a corrupt government, which asked for nothing but blind loyalty, would cure the abuses under which the people groaned, or reform the State? The woes of Italy increased, but the more her institutions were corrupted, the less they had to fear from the assaults of the reformer. The vices which were the allies of the government, such as the idleness, the drunkenness, and the festive dissipation of the people, the frivolity of the upper and middle classes, enjoyed a large measure of official protection. Every manifestation of high culture was frowned upon, if not persecuted. Serious study was discouraged. The workers in literature, art, science, if they did not conform their productions to the flattery of the great, had to proceed very warily, for night and day they 
were under the eyes of a jealous and malignant censorship.

Governments so weak and so insecure-always dreading that at any moment the Dragon of $\mathrm{Re}$ volution might break its bonds-necessarily regarded Austria as a kind of St. George of law and order, for it was Austria who had slain the Dragon. But Austria bestowed her protection with such skilful perfidy! She did not exactly treat Lombardy and Venetia as slaves; she allowed them, for example, some slight freedom to read and to study, to discuss and even to carry out some mild reforms, and to receive, from France, England, and Germany, some not too perilous innovations. Compared with the strict embargo imposed on all the other States in the peninsula, except the Grand Duchy of Tuscany, such a rule might almost seem to be the beginnings of liberty. Elsewhere, however, Austria supported the most reactionary parties and forcibly strangled at birth all desire for reform, all aspirations towards freedom, all criticism and expressions of patriotism, and all longing for innovation. It is easy to understand the object of this policy. It was to persuade the Lombards and the Venetians that to be subjects of the Hapsburgs was the greatest good fortune that could befall any momber of the Italian family, 


\section{The League of the Dynasties}

and to bind to herself body and soul all the other governments in Italy: The more they belaboured the chained Dragon of Revolution, the more they were bound to dread its breaking loose, and the more they were bound to fall on their knees and worship the invincible lance of the new St. George. This foreign power, which by turns oppressed and favoured parties and persons according to the dictates of its own interests, depraved and divided the whole peninsula. The oppressed despaired of liberty and justice, and even of revenge, while the oppressors, believing themselves invulnerable grew more insolent and cruel. Austrian protection, in fact, corrupted the very marrow of the new Italian governments of 1815 , the bones of which were rotten from their birth, and this corruption attacked not only the States, great and small, into which the peninsula was divided, but also an institution in their midst which was of much greater importance by reason of its past and of its spiritual authority-the Church.

It is necessary to elaborate this point as it would not otherwise be possible to explain the implacable resentment felt by the Italian Revolution towards the Papacy-an antagonism of which in later days, the astute ambition of Prussia was destined to take advantage. After the Reformation in the 
seventeenth and eighteenth centuries, the Church had been purified. She had devoted herself in good earnest to the improvement of the world, and to that end had utilized the service of distinguished moralists, the last of her great Saints, educational and charitable institutions, new and renovated monastic orders. The nineteenth century owed some of its virtues to the education which Catholic Europe had received from the Church during the previous two hundred years. But no institution had suffered more from the ruin into which all principles of legitimate authority fell, one after another, towards the end of the seventeenth and the beginning of the eighteenth century, because none depended more on a foundation of respect. What could she do when she had lost that respect, and Europe-Revolutionist and Royalist alike-leapt upon her, mocked and trampled upon her spiritual aims, despoiled her of her wealth, of almost all her ancient privileges and of the State which she possessed in Central Italy? When the great revolutionary crisis was over, and she was able to free herself from her persecutors, and struggle to her feet again, she was no longer what she had been. She had lost faith in her own authority. She had become so terrified of the Revolution that she was 


\section{The League of the Dynasties}

no longer able to protect herself without an armed champion. After 1815, the Government of the Church was the weakest in all Italy, the most menaced by the memories and the ferments left behind by the French domination, the one which had the most to fear from the destruction of the order of things established by the Congress of Vienna, and most depended on the support of foreign armies. From weakness, fear, and devotion to the little State it possessed in Central Italy, the Papacy then made the mistake of authenticating the false patents of Divine Right granted to itself by the Congress of Vienna; for the eternal principles of order, it exchanged the ephemeral interests of a party, destined, like a worm, to live for an hour. It confronted the new spirit, which was endeavouring to reanimate Italy, with clergy, high and low, charitable institutions, and monastic orders, and by so doing, it aroused the antagonism of that spirit. It was in vain that the finer spirits within and without the Church protested and lamented. That which in the eighteenth century had been a lofty throne from which a Clement XIV. had spoken, was now a little Court of astute and timid politicians, protected and dominated by Austria under the pontificate of a Gregory XVI. The decadence of the higher clergy kept pace with 


\section{4}

\section{Problems of Peace}

that of the Roman Curia. In both, during the first half of the nineteenth century, those who succeeded were narrow-minded fanatics and unscrupulous intriguers. Boldness and ignorance, hypocrisy and corruption, reigned supreme. The greater institutions became mummified, and as a necessary consequence, the soul languished. Such a decadence was rightly more odious to its contemporaries than that of any other institution, for the office of the Church was to correct the abuses of corrupt Government, not to propagate them by her example.

An ancient Italian legend tells how a tyrant destroyed his victims by chaining each to a corpse. The Empire of Austria had bound the Italian people to the corpse of a dead age. This was the torture to which the peace of the monarchs had condemned Italy. Nor, though the torments were different, had France and Germany been spared. Italy and the Balkan Peninsula were the most afflicted parts of the Continent, but the heart of Europe was diseased as well. The Congress of Vienna had wished not to leave between the solid unities of France and Russia, the fluid disaggregation of little less than forty independent ${ }^{\mathrm{x}}$ States of

\footnotetext{
Ihere were, to be precise, thirty-four States and four free cities.
} 


\section{The League of the Dynasties}

which Germany was composed, even after the concentration and unification brought about by the Revolution. Owing, however, to the rivalries, the distrust, and the pride of the Courts, ancient and modern, it had not been able to gather them all together again under the sceptre of the old empire nor to bind them together into a true confederacy. After much discussion and many proposals, it had been finally arranged that they should unite under the name of the Germanic Confederation, in a compact of mutual understanding and for common defence. Austria and Prussia were members of the Confederation but only so far as regarded such of their territories as were inhabited by Germans. A Diet, meeting at Frankfort and composed of representatives of all the Confederate States, had the authority to make laws of general concern. States which had no territories outside the Confederation could not make war without its consent. Yet the Confederation had an army under the control of a State the greater part of whose territories were outside the Confederation, and which for that reason had little concern with the affairs of Germany. Undermined by the jealousies of Prussia and Austria, represented by a Diet to which the people had no access, and whose powers were ill-defined, lacking an authoritative 
head and vigorous organs of government, the Germanic Confederation was a mere skeleton. This skeleton the Congress of Vienna had invested with the Crown and Sceptre and the ermine of the ancient Empire-an almost sacrilegious parody in the eyes of Germany, which was roused at last, but too late.

It was in the last days of Napoleon that Germany had awakened from her slumbers in the bosom of the Holy Roman Empire. During the Campaigns of 1813,1814 , and 1815 she had found again her ancient passion for dangerous adventure, had recovered her self-confidence, and had given the first proofs of her strength without exhausting it too much as France had done. She had, however, intervened in the great movement of the century only when it was about to come to an end. Thus she was placed in bondage by the treaties of I8I4-I8I 5 to a peace and a league imposed upon her by the arbitrary agreement of the sovereigns at the very time when, having laid all heaven under contribution, she was beginning to wish to do something similar on earth. Germany, therefore, like Italy, raged inwardly but did not know whether her misfortunes were due to her own impotence or to the servitude to which absolutism had condemned her. At one moment she longed 


\section{The League of the Dynasties}

for unity; at another she demanded freedom; sometimes she cried out for both. At times, she resigned herself to accepting the domination of absolute monarchs, a narrow aristocracy, and irresponsible functionaries, but again she would lament that all access to office was barred to men of ability without ancestors and open to descendants without ability, and that thought was hampered by censorship and inspection by the police; and she longed to destroy the antiquated mise en scène and machinery of Divine Right.

On the other hand she was distressed to see the fragments of German unity which had been shattered by the Reformation still lying dispersed all over Central Europe. She reproached her dynasties and her governments with sacrificing Germany to their personal interests and to peace, and sighed for a despot through whom her unification might be accomplished. Unlike Italy, she was not oppressed by a foreign power with overwhelming forces which kept the nation at discord with itself. Her governments, though suspected and tyrannical, did not suffocate the intelligence of their subjects. It was not their object to make ignorance a bulwark against revolution. They at least allowed men to dream in prose and verse, to rave in the pages of history and in volumes of 
philosophy. Though her desires were unsatisfied, though she was still waiting for her unification and working hard to repair the losses of the Napoleonic Wars, Germany was not, like Italy, reduced to despair of herself, her future, and the whole world. On the contrary, she lent a willing ear to the seductive flatteries of her historians who hailed her as the greatest nation on earth, fomented her hatred of France, and by falsifying the past encouraged the most extravagant expectations of future fortune. Megalomania, suspicion, national hypersensitiveness, a tendency to believe herself the victim of other nations, bitter hatred of Franceall these delusions which for four years we have seen raging on land, on sea, and in the air date from long ago. They had begun to torment the soul of Germany in 1815 .

France had no more reason to be satisfied than Germany. The peace treaties of I8I4 and I8I5 had deprived her of all she had won in twenty-five years of war. They had moreover imposed upon her a dynasty whose ancient titles of legitimacy were no longer recognized by part of the population, and which could not acquire new titles by new enterprises. Pledged to respect the peace of the sovereigns, hostile to revolutionary and $\mathrm{Na}$ poleonic memories, insecure as regards its own 


\section{The League of the Dynasties}

fortunes reborn from the defeat of the country, the Restoration had even decided to disband the glorious armies of the Revolution and the Empire, to abolish conscription, and to return to military service on the professional principle. This design had been given up because France now required so large an army that its ranks could not be filled by voluntary recruiting. But, though the Restoration was thus forced to use the armies of the Revolution and the Empire, these armies were spoiled and weakened as much as possible; they were distrusted and condemned to be the silent guardians of a somnolent peace.

While Germany was distracted with a wild longing for action, France, either exhausted by her many trials or disgusted with the mediocre position to which she had been condemned after so many glorious adventures, set about building the mystic city of the future in those vast fields of thought which Germany until a few years before had raided so impetuously. It is well known that the most famous German systems of Philosophy were eagerly studied and professed in France under the Restoration at a time when their vogue in Germany had already long ceased, a circumstance which led Edgar Quinet to observe that in Philosophy France "had adopted only the dead." But 
in this world there is no question of a philosophy being living or dead. A philosophy serves the interests, the passions, and the vital needs of an age and then ceases to be and is abandoned like a dead thing when it is no longer useful. The wild Teutonic systems which Germany had ceased to study, poetic vehemence, the sentimental melancholy, and the theatrical rebelliousness of German romanticism, satisfied the restless quest for new jdeas, new doctrines, and new kinds of beauty with which France was consoling herself for the mediocrity of her everyday life. They nourished the fervid idealism in which Christian mysticism was mingled with the humanitarian aspirations of the Revolution and the heroic spirit of the Empire, and which generated so many high-minded theories, from the doctrines of Lamennais to those of socialism, from the School of St. Simon to that of Fourier. Among these theories there was one which many generous and ardent spirits set up against the prudent and constant attachment of the Government to peace, and this was that it was the mission of France to break the peace of the sovereigns, to free the oppressed peoples of Europe, and to bring about a true peace based on the brotherhood of redeemed nations.

The position of Germany more resembled that 


\section{The League of the Dynasties}

of Italy than that of France. Both Germany and Italy had to lament the loss of liberty. Both complained that the indivisible soul of the nation had been shattered into a great number of small States at variance with each other when not actually hostile. Germany and Italy should therefore have been bound together by mutual sympathy in a common misfortune. But this did not come about. Even then the German people wanted unity only in order to despoil others. The parties opposed to absolute power were already bitterly reproaching the German dynasties because they had not deprived France of Alsace and Lorraine in 1815 but in order to have peace had allowed her to keep these provinces. They never showed the slightest sympathy for the Italian provinces oppressed by Austria; on the contrary they openly rejoiced that the strongest power in the Germanic Confederation held Italy fast in its talons. France, on the other hand, which had for so many years dominated Italy and had been excluded in 1815, which might have looked on the affairs of the peninsula with the rancour of defeat and a longing for revenge, was moved with compassion at the sufferings inflicted on Italy between I82I and I830 by the arrangements of the Congress of Vienna, and by the turbid policy of Vienna, and 
the Bourbon Government was constrained to turn its attention to what was happening in the peninsula. After the year 1825, difficulties and differences arose between the Kingdom of France and the Empire of Austria on the subject of Italian affairs.

In short, though it would be an exaggeration to say that while in 1830 the sovereigns wished to keep the peace the peoples wished for war, it is nevertheless true that in France and Germany the peace of the sovereigns appeared to those who were opposed to absolute monarchy as a kind of prison in which Europe had been confined by pusillanimous monarchs who wanted to enjoy the sweets of power without its difficulties. England, Austria, and Russia on the other hand were as tranquil as any European State could be in these trying times, because they were satisfied with the order of things established by the Congress of Vienna. When the affairs of Europe had been resettled, England had retired to her island and had busied herself with the development of her commerce. She took no interest in continental affairs except in so far as these affected the peace and quietness of the world which was essential for her comfort. The protocols of the Congress of Vienna appeared to her therefore to be perfect and practically un- 


\section{The League of the Dynasties}

alterable. Only a few men of intelligence above the average shook their heads over this shortsighted egoism. Although there was smouldering nationalist discontent in Bohemia, Hungary, and Italy, in Austria the dynasty was strong enough, in spite of the weakness of the Emperor, to quell or overawe every manifestation of liberal unrest or opposition. The prestige of its authority had been much increased in 1814 and 1815 . The untiring watchfulness, the strong intelligence, and the astute caution of Prince Metternich, as well as the devotion of the Teutonic aristocracy, were the foundations of the new Austrian power which seemed sure of itself. In Russia, finally, there had appeared a strange giant, violent and mild, capricious and tenacious, good and bad, lovable and terrible, who, through all the alternations of an unstable temperament, firmly adhered to one fixed idea, which was to be the chief prop in Europe of legitimacy, absolutism, and the Holy Alliance. This was Nicholas I. who ascended the throne of Russia in 1825 on the death of his brother Alexander I. Nicholas not only believed in absolutism and Divine Right with a mystical fervour but thought of himself as the Head of the great family of the crowned heads of Europe. He thought it to be his duty by example, advice, and, if necessary, 
reproof, to keep them all firm in the defence of their principles and of the common cause. His passionate energy enabled him to acquire a great ascendancy over many weak or sceptical princes. His authority in the German courts was great, and greatest of all after 1840 in that of the King of Prussia, Frederick William IV., who admired and loved him so much that to his courtiers it seemed to border on adoration.

Neither the contented egoism of the English people, however, nor the haughty mysticism of Nicholas I., nor the astuteness of Metternich and the renovated prestige of the Hapsburgs, could long maintain intact a state of matters against which were leagued so many sorrows, hopes, and aspirations. Six years after the Congress of Vienna, Revolution had tried to break its chains in Piedmont. In 1830 it succeeded not in the capital of a little State but in Paris itself, the city of its birth and its historic seat. Legitimate government on the bare word of the Bourbons had not been able to resist for more than fifteen years the discontent of the middle and educated classes who wished for a larger share of power, and the national vanity which was wounded by the inertia of the Government and by its connivance at the work of the enemies of France. In July, 1830, the people of 


\section{The League of the Dynasties}

Paris rose and overthrew the Bourbons. They were successful not because the people in arms were invincible, but because the army in Paris, recruited from the people and affected with its discontent, hesitated at the critical moment, and the monarchy, feeling its forces fail, ceased to trust to its counterfeit legitimacy, threw crown and sceptre to the rabble, and fled. The Holy Alliance was horrified to see the Revolution in Paris with gunpowder-blackened hands crowning Louis Philippe of Orleans King of the French. From one end of Europe to the other the principle of legitimacy tottered. Belgium revolted, determined to be separated from Holland. The States of Central Germany already in possession of constitutional government, such as Bavaria, Württemberg, and Baden, were in a state of unrest and seemed inclined to turn their backs on Prussia, which remained obstinately shut up in her obscure absolutism, and to worship the sun which was rising in France. Poland rose in rebellion. In Italy, a revolution broke out in the Papal States and at Bologna the deposition of the temporal power of the Holy See was proclaimed. Some hoped and others feared that the peace of the sovereigns was about to be broken, not by the insurgent peoples who were weak, but by the new King of the French 
who had received his sceptre and his sword from the Revolution. Had not the Bourbons been overthrown by national exasperation at the humiliation inflicted on France by the Congress of Vienna? Had not the Revolution of I830 been the signal for the revival all over France of her mystic faith in a mission to free the world? Would not the new King have to try new ways if not for the love of glory at any rate from hatred of his predecessors? The memory of the first revolution was too fresh for Europe not to fear or hope that the second would in all respects follow in the footsteps of its predecessor. And in fact, on December I, 1830, Lafitte, the President of the Council of Ministers, declared in the Chamber that "France would not permit any great Power to intervene either in Belgium or in Italy to overpower by force the will of small nations." Sebastiani, the Minister of Foreign Affairs, at the sitting of December 28th, contrasted this policy with that of the Holy Alliance.

The Holy Alliance has made its own the principle of intervention which annihilates the independence of small nations. The principle of non-intervention which we support, and for which we shall know how to secure respect, secures liberty and independence for all. 


\section{The League of the Dynasties}

The right of small nations to dispose of their own governments, of which so much has been heard during the European war, had already appeared in the protocols of French diplomacy in I830.

Its appearance was, however, timid and short. It lasted until the Austrian Empire in Italy met the prohibition lodged by France by intervening first in the Duchies and then in the Legations to repress the revolution. This at once confronted the Government of Louis Philippe with a dilemma. They had either to make war or to yield. They yielded. Great was the resentment of the Italian liberals who roundly accused the French of betraying them. This was very natural, but it is easy to see how it was that when the France and Austria of that day confronted each other, France after her rash threats did not dare to strike. How could France make war on Austria in Italy and for Italy in the face of English, Russian, and German disapproval without a point d'appui, a base of operations, and a secure ally in the peninsula? Such an ally would only be Piedmont, the guardian of the gates of Italy, who in those days kept guard in the interests of Austria. Since 1815, Austria had spared no pains to keep Piedmont under her control for this very purpose, and had exported many an archduchess to espouse the Princes of 
the House of Savoy. Austrian influence was so powerful at Turin that in I83I Charles Albert, who had succeeded his brother Carlo Felice, though tinged with liberalism, and even Carbonarism, had been immediately compelled to yield to the Austrian party and to ingratiate himself with the all-powerful empire. For France to attack Austria in Italy without an alliance with Piedmont would have been as mad an enterprise as to attack the moon.

Thus, although the Revolution of 1830 seemed to the hopes and fears of its contemporaries to possess the stature, the features, and the fiery impulse of its great sister of I789, the second Revolution was after all but a little sister, lacking the élan, the audacity, and the mystical self-confidence of its predecessor. Using the cold calculations of the politician and the soldier, the Revolution of I830 decided that Austria was too strong in Italy, and the Holy Alliance in Europe, and felt unequal to defying them. Italy was therefore abandoned to the talons of the two-headed eagle. Neither could France do anything for insurgent Poland nor encourage and help, nor enlist on her side the revolutionary unrest which had been stirring the constitutional States of Germany since its success. Nicholas I., whose teeth had 


\section{The League of the Dynasties}

been set on edge by the admission to the fanily of crowned heads of the new King who owed his royalty to the Paris revolutionists, pitilessly repressed the Polish rebellion. He encouraged the German sovereigns to yield nothing to the unrest of their subjects who had been stirred by events in Paris. And so the Revolution of 1830 , restrained partly by its own weakness and partly by the strength of the opposite principle, did not dare to cross the frontier. Belgium alone gained by it, being recognized by the Powers as an independent State under a monarchical government limited only by its neutrality - a precaution taken by England against France, which in 19I4 was destined to become suddenly a deadly danger for England herself. As the movement had failed to spread over Europe, it soon exhausted itself in its own country in trifling reforms carried out behind closed doors. Little by little, Louis Philippe reconciled himself with the Holy Alliance, made his peace with Divine Right, came to an understanding with Austria, and entered the League of Monarchs for preserving peace. He continued to respect the representative institutions which he was not strong enough to destroy, but he took care that even in France the Government should remain in the hands of a narrow oligarchy of nobles and rich 
men, the people being excluded and the middle and educated classes reduced to the position of clients. He sought an outlet for the heroic aspirations of a section of French opinion in the conquest of Algeria, and he tried to stifle the romantic longings, the ambition, the fighting spirit, and the criticisms of the political parties and the intellectual classes by encouraging the pursuit of riches.

An immense change in the history of the world was beginning. The era of iron and fire, of railways, and steam machinery had commenced in England, France, and, to some extent, in Prussia. Men who by the aid of a few machines of wood, actuated by water or animal power, had hitherto made a few things of excellent quality with much patient labour, now had it in their power to make and drive machines of iron which were capable of tirelessly repeating the same movements night and day with prodigious rapidity, and of producing in an hour what could not be made by human hands in a whole day. "Are they gods or devils?" was the question which men put to themselves in anxiety and stupefaction in the presence of these machines. They had some of the attributes of divinity, for they could annihilate time and space; they produced abundance and worked miracles. 
But they were creatures of man, made by his hand for his service, and could man create divinity and have it for his slave? For a time the world hesitated, but England led the way, crying that the machines were powerful giants and at the same time docile servants of man who, obedient to his nod, would bring back the golden age and a time of plenty on earth. Now France, under the reign of Louis Philippe, began to follow England's example, and to people the world with these new and miraculous giants, and it was not long before she was imitated by Prussia. The Prussian monarchy, meekly obeying the influence of the Russian Court, remained firmly attached to the principles of absolutism and to the policy of respecting the peace of the sovereigns. But, in compensation for that, every care was at once taken to help the people to increase their riches. On Prussian initiative, a Customs union between the States of the Germanic Confederation, excluding Austria, was established in 1834, so that Germany became at least an economic unity. As far as was possible (Prussia was then still a poor country) the Prussian government encouraged and assisted its subjects to appropriate to themselves all the new scientific industrial discoveries which could increase the power and well-being of the nation. 
Austria was more diffident. Without openly combating the new industries she favoured them less than England, France, and Prussia. The absolute governments of Italy, on the other hand, proscribed industry on the great scale altogether. There should be neither banks nor newly invented machines nor even railways, for they secretly identified all these innovations with Revolution. The first line of railway in Italy, that from Naples to Torre Annunziata, was not built until I840, and not more than 233 kilometres of track had been constructed before I848. A new humiliation was added, therefore, between 1830 and 1840 to the old, and it cut to the heart every Italian who admired from afar the development of European civilization. While each day brought wonderful strides of progress to other peoples, while man was on the point of becoming omnipotent, thanks to the new titans, was Italy alone to vegetate in poverty, idleness, and ignorance, chained to the customs and the ideas of an age that was now dead? Though she had lost all hope of succour from France, Italy could not resign herself to such a fate, and she grew more and more restless, especially after $\mathbf{I} 840$. From one end of the peninsula to the other books and theories multiplied. Giuseppe Mazzini predicted unification and a republic, Vincenzo Gio- 


\section{The League of the Dynasties}

berti federation under the Presidency of the Pope. Others dreamed of a catholic renaissance. A few began to hint at a social revolution which would cure all ills by destroying them utterly, while some good patriots in their despair and disillusion asked whether, since Lombardy and Venetia were the only provinces which enjoyed some slight measure of liberty and not wholly inept government, it would not be better that Austria should take possession of the whole peninsula. The unrest over all Europe, which gradually increased as the generation grew up which had not seen the wars of the Revolution and the Empire, the opposition to absolutism of the middle and cultivated classes, and even of part of the autocracy, which grew stronger every year in every country, encouraged the ardour of Italy. Every now and then a group of high-spirited and impatient young men would join in an attempt at revolution and remind Europe that Italy was still alive and still afflicted. Finally, in 1846 , because the Hapsburg veto did not arrive in time, the Conclave elected as Pope Cardinal Mastai Ferretti, a high-minded man who was opposed to the horrible government which tormented the States of the Church. He immediately proclaimed an amnesty-initiated several timid but good reforms, and set an example by which 
64 Problems of Peace

Italy was deeply moved. It almost seemed as if Gioberti's prediction was about to come true when Europe was convulsed, as by an earthquake, by the Revolution of 1848 . 


\section{CHAPTER IV}

\section{THE REVOLUTION OF 1848}

THE convulsion of 1848 was universal. This time the Revolution scoured Europe. It began in Sicily, which revolted on January I2th, compelling the King of Naples to grant a constitution on February Ioth. Next came the turn of Paris which towards the end of February upset the monarchy of Louis Philippe and proclaimed a Republic. Once more a government whose only secure title to authority was force gave itself up for lost and fled the moment its army, infected by the public discontent, showed signs of vacillating. But no sooner did it become known in Europe that the Republic had re-arisen from its tomb in Paris, than there was a universal explosion of all the aspirations, the ambitions, the illusions, and the resentment that had been accumulating in the hearts of the educated bourgeoisie for the last thirty years.

In Piedmont, which had for years been restless, Carlo Alberto had no alternative but to grant a 
constitution on March 4th. All Germany was thrilled. Liberal constitutions, abolition of privilege, freedom of the press, the arming of the people, the right of petition and association, public and oral procedure in the courts, liberty of conscience, the unification of Germany, popular election to the Diet of the Confederation;-all these things were demanded by Germans who had suddenly awakened, in mass meetings, in the public newspapers, and in their legislative assemblies. On March 19th, the populace of Berlin rose in rebellion and discomfited the army, but, having broken this barrier, they did not proceed as at Paris, to overthrow the monarchy. On the contrary they contented themselves with the King's promise that a constitution should be granted to them and that their States and Princes would be summoned to form a common assembly which would provide for the destinies of Germany. In this plan the King of Prussia had been anticipated by a Committee of patriotic Liberals which met at Heidelberg on March 5th and drafted a scheme for a national German Parliament, inviting all past and present members of German legislatures to come and discuss it at Frankfort on March 3oth.

Even more violent was the repercussion of the 


\section{The Revolution of 1848}

Paris revolution in the Austrian Empire. In the early days of March the Hungarian Diet, declaring itself a Constituent Assembly, approved a body of laws which made Hungary a constitutional State. On the $13^{\text {th }}$, disturbances began at Vienna. On the I 5 th, the Emperor dismissed Prince Metternich and half his Empire was immediately in flames. In Bohemia the people of Prague met and appointed a kind of Provisional Government under the name of the National Committee which sent two delegates to the "King of Bohemia" at Vienna to demand the restoration of a united Bohemian Kingdom under constitutional government. At Agram a Croatian national committee was constituted which appointed General Jellachich as Ban and sent a deputation to Vienna. Italy revolted. At Venice, Brescia, and Milan the people took arms and drove out the Austrians. The revolution even reached Denmark where the Duchy of Holstein, inhabited by Germans and forming part of the Germanic Confederation, rebelled. In a few weeks the whole fabric of Divine Right and the false legitimacy of the Holy Alliance, like a canvas building whose inward support has given way, collapsed all over Europe except in Russia. There Nicholas I. was on his guard. 
But, though all the greater nations of Europe

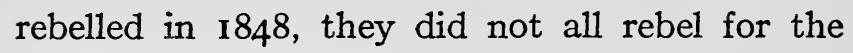
same reasons. In $\mathbf{1} 848$, it was not a single revolution but a catena of separate revolutions. In France the revolution upset not only the oligarchy of nobles and moneyed men which had enabled Louis Philippe to dominate the country through his Court and his Parliament. It had at once attempted a greater achievement-no less indeed than to locate finally in the Will of the People the new fount of legitimate authority and a spiritual force which was capable of giving men the justice, liberty, and happiness which had been falsely promised them by the régimes which had passed away. In the presence of the ruins of the second kingdom which had been overthrown by the people little more than thirty years after its foundation, first the actual combatants and then the whole of France were seized with an immense enthusiasm. Did not these victories prove that the time had come when the people would no longer be the despised flock at the mercy of so many false authorities, human and divine, but the strong, wise, and just shepherd of itself?

Carried away by this enthusiasm the Provisional Government had proclaimed a Republic, subject to the ratification of the people, who 


\section{The Revolution of $\mathrm{I} 848$}

should be called upon all and sundry to elect a Constituent Assembly. They had set about preparing the election of this body, or rather taking the preliminary steps which were necessary in order that the miracle in vain attempted by the first Revolution should now be performed before the eyes of an astonished world. That miracle was that the people, liberated from its chains, should remove the final cause of all tyrannies by solving the irreconcilable contradiction between the right to command and the duty to obey, and fusing them in its own will obedient to itself, obeying itself as if another had commanded, and commanding itself as if another was to obey.

In Piedmont the movement which had threatened to develop into a Revolution had a political object. It did not seek to introduce a new principle of authority into the world but merely to open the gates of power slightly, and, by means of a prudent constitution with a timocratic and oligarchical franchise to admit a part of the rich and educated bourgeoisie. Milan, Venice, and Brescia, on the other hand, had made a revolution in order to drive out the foreigner. In Vienna the Revolution was aimed at absolutism and the aristocracy, while in Bohemia and Hungary its efforts were directed to securing at the same time 
liberal institutions and deliverance from the German yoke. In Germany, finally, the Revolution dreamed confusedly of giving the German peoples liberty, unity, and, above all, their old imperial power.

Thus the history of 1848 and of the following year is at the same time unified and disjointedunified because the popular movements were interconnected, disjointed because, although they sprang one from another, they were often different and sometimes contradictory in character. Together they form a disparate unity which it is difficult, but necessary, to study, for in it we shall find the seeds and the beginning of all the crises, the struggles, and the disturbances which agitated Europe until the outbreak of the world war.

Meanwhile there appeared on the barricades of Paris, for the first time in history, two personalities destined to be much talked of thereafter-the Proletariat and Socialism. The giants of iron animated by fire which men adored as gods, and which they proposed to use as slaves, had increased in numbers, in power, and in size during the previous twenty years, vitiating the pure air above a hundred cities with their sooty breath. But mankind had waited in vain for the benefits which had been hoped for when they made their appear- 


\section{The Revolution of 1848}

ance. Indeed it had been asked whether, after all, these supposed gods were not mocking and malignant demons who were making game of their masters. It was true that they could produce abundance, but that abundance, far from proving a blessing, seemed to be a new disaster worse than the old scarcity. For, when things became plentiful and cheaper and people hoped to enjoy them freely, at once factories were closed, industries went bankrupt, and the workmen. thrown on the streets, found themselves languishing with hunger on the threshold of warehouses crammed with commodities which were useless because, while one party was unable to sell the other was unable to buy.

Neither was the hope confirmed that these new divinities would liberate men from the servitude of labour. On the contrary, the artisan now had to work more than ever-from dawn till dusk, day and night, without raising his eyes from his machine for a minute. He had to labour in silence like a prisoner under the compulsion of implacable taskmasters, in immense workshops where the light was often bad and the air mephitic, and where any one who entered had for the whole day to make himself a temporary slave, abdicating all his rights as a man and a citizen, and bowing before 
a master who for him was little less than a god, because it was he from whom men had now to ask that for which they formerly prayed to God Himself-their daily bread. They were fortunate if this subsistence, gained with so much travail and humiliation, was at least secure and continuous. When one looked from the misery of the common people to the riches of the great there was no comfort in the comparison. These gods on earth seemed to spread a contagion of evil passionscupidity, pride, venality, tyranny, envy, treachery, fraud, and injustice. The thirst for gold had perverted the world; everything was, or was on the point of being, for sale. Genius, justice, truth, science-all the good things of the world seemed to come from a mocking God who delighted in outraging intelligence, virtue, and merit. Everywhere successful and unscrupulous cunning was seen reaping the harvest which had been sown by genius, courage, or sagacity.

These evils are common to all countries in the first days of the development of industry on the grand scale. France, however, had suffered more keenly because she was a cultivated nation, refined by many centuries of civilization, by the heroic ideals of chivalry, by classic culture, by catholicism, by the generous hopes of the eight- 


\section{The Revolution of 1848}

eenth century and the Revolution. Was France, therefore, to conclude that the pretended gods were monsters, hostile to mankind? Fascinated as she was by the noble utopias of progress, she did not dare to condemn one of its most portentous manifestations. She accused herself, and blamed the ignorance and the selfishness of men themselves, who spoiled the divine gifts of which Progress was so liberal. It was between 1830 and I 848, in the midst of the ideal fervour by which France was so deeply moved, that socialism was born, or rather vigorousy developed from germs left behind by the Revolution but hitherto dormant.

This body of diverse doctrines, often confused and faintly adumbrated, spread rapidly among the workers in the great cities. Its grand object was to discover the miraculous secret which would cleanse the great industries of the cruelties, injustices, corruptions, and perversions with which they were stained through the fault not of its godlike machinery, but of the men who were unworthy to control it! Socialism was propagated by a band of writers, some ingenious, some puerile, some fantastic, and some profound, pre-eminent among whom was Prudhon, one of the most powerful minds of the century. It occurred 
to none of them to inquire whether there was not a revival in the world of the ancient fire-worship professed by mankind many thousand years ago.

On the barricades of $\mathbf{I} 848$, as in preceding revolutions, the workmen of Paris had fought in great numbers. In other European States the rebellion had been mainly a revolt of the educated bourgeoisie, aided no doubt by the workers, against absolutism and government by aristocracy. In France it had also been a revolt of the Socialist proletariat against what was afterwards called the capitalist régime. This time the workers not only demanded as the prize of victory liberty, the right to vote, and a republic. They required, and secured, the admission to the Provisional Government of three representatives of Socialism, Flocon, Louis Blanc, and Albert. On February 28th they went in a great procession to the Hôtel de Ville, brandishing before the eyes of the Parisians banners on which was inscribed "Ministry of Progress and Organized Labour." They compelled the Provisional Government to set up on that very day a government commission for workmen, whose duty would be to study the labour question. They desired the Commission, through a delegation appointed by their 


\section{The Revolution of 1848}

unions, to diminish the hours of work, and they set on foot an agitation with a view to securing that the new Republic should recognize the right to work in its fundamental laws. Were the men, who for so many centuries had had to be compelled to work as a duty, now freely offering their shoulders to the burden and loudly demanding work as a right? Was what had of old been considered a heavy burden now to be regarded by a better and a wiser humanity as the greatest and most longedfor blessing that could possibly be conferred upon it?

By no means. The right to labour claimed by the workmen of Paris was a bitter protest against the cruel caprice of the mysterious divinities who every now and then suspended operations and condemned thousands of industrious workmen to weeks and months of idleness and hunger. But the progress of the human race towards wisdom had been so slight, and the divinities they worshipped inspired such terror, that the Revolution did not dare to command them to be less capricious; in fact it was soon much perplexed and worried by all the demands made upon it, and above all by the new and strange mania of men for constant work. These agitations and demands on the part of the workmen were the cause of the 
first discords within the Provisional Government and the first anxieties in the public mind.

While the Revolution was parleying with socialism at Paris, in Italy and Germany it broke, after thirty-three years, the peace and the league of the dynasties. In Germany the Confederation, urged by public opinion, declared war on Denmark in order to liberate the Duchy of Holstein, which had rebelled, and placed the King of Prussia in control of the conduct of the war. In Italy the people which the Holy Alliance had bound living to the corpse of its dead past suddenly broke loose and attacked the Austrian Empire. The movement, which forced Carlo Alberto's hand in Piedmont, had been more political than nationalist. When, however, it became known at Turin that a revolution had broken out at Vienna, that Venice had risen, that the Austrian Army, after fighting in vain for five days against the people, had evacuated Milan and retired into the Quadrilateral, that the senior Austrian FieldMarshal with all his military science and all his numbers had been beaten by the sublime impetuosity of an insurgent people practically without arms, public feeling burst forth with greater vehemence than ever and, having secured their constitution, they now demanded war against Aus- 


\section{The Revolution of 1848}

tria. Lombardy must at once be invaded, assistance given immediately at Milan; the Austrians must be driven from Italy and the whole peninsula freed from foreign rule. Fortune had provided an opportunity which would never return! The movement of public opinion was so violent that on March 27th Carlo Alberto crossed the Ticino at the head of his army and almost all the States of Italy, including the Holy See and the Kingdom of Naples, compelled by the sentiments of their peoples, made common cause with Piedmont by sending soldiers to fight against the Austrian Empire.

The Hapsburg dynasty was therefore caught between the two fires of foreign war and internal tumult. In the month of April, while Carlo Alberto was victoriously advancing in Lombardy and Venetia and had come within sight of the towers of the fair city of Verona at the foot of the green hills which line the banks of the Adige, the Emperor Ferdinand had sanctioned the constitutional laws passed by the Hungarian Diet, had agreed to the Bohemian Charter, which promised that the Bohemian provinces should be united under a government responsible to the legislature, had confirmed the election of the Ban of Croatia who had been chosen by the people, and 


\section{Problems of Peace}

finally, on April 25th, had granted the promised constitution.

Two days earlier, on April 23d, while the Easter bells were ringing, Universal Suffrage, with a composure and a regularity appropriate to a long experience of sovereignty, had elected in France by scrutin de lista, and without any disorder, the National Assembly which was to draw up the statutes of the new Republic. By comparison with this fulness of sovereignty possessed by the French people the Viennese were humiliated by the grudging concessions of the Emperor. The new constitution did not provide them with Universal Suffrage, and, as they did not choose to receive freedom and sovereignty as a gift, they protested violently and the defective constitution was withdrawn. In Italy, in April and May, the tide of Revolution seemed here and there to recede somewhat. On April 29th, the Pope had declared in a celebrated Encyclical that, as Father of all Catholics alike, he could not make war on Austria, and in May the Austrian party again raised its head at Naples. The King dissolved Parliament and withdrew his contingent from the national war. Though the Hapsburgs were making terms with the Revolution in their own empire, they were none the more ready to renounce 


\section{The Revolution of 1848}

the satisfaction of stabbing it in the back in Italy, pending the time when they could meet it face to face.

The transition in the Italian States from fidelity to Austria to war and revolution had been too abrupt. Austria had retained too many understandings, too many friendships, too many partisans in the midst of these enemies of a day, who for so many years had been her clients. Yet these checks were small in comparison with the victories which the Revolution, to all appearance, continued to gain everywhere. On the fourth of May, the National Assembly at Paris met in solemn session at the Palais Bourbon. The Provisional Government was dissolved and, pending a decision as to the Presidency of the Republic, power was entrusted to a commission of five to appoint a ministry. On May I6th, the Emperor of Austria transferred constituent powers to a Chamber of 303 deputies elected by Universal Suffrage. On May I8th, there met at Frankfort the Germanic Parliament, which had been elected by Universal Suffrage on the initiative taken in March by the Heidelberg Committee and in accordance with the rules laid down at the Frankfort meeting which supplanted the Diet of the Confederation.

The Revolution, however, was at this moment 
more endangered by its victories than by its struggles. Difficulties began not where it was still at grips with an unexhausted or even an actually more powerful enemy, but in France, where its success had been complete. Universal Suffrage had not been dominated by prejudice or rancour or by any form of exclusiveness in choosing the members of the Assembly. It had been desired that men of eminence in every branch of human knowledge and activity should form part of it, that all ranks, from the nobles to the peasants, should be represented, that the liberal professions, the clergy no less than commerce and industry, should have their share. Accordingly there were champions of all parties and of every doctrine, from Legitimism to Socialism. The Socialists, however, were very few in number, and, of 900 deputies, about 450 were former monarchists, Legitimist and Orleanist, while the other half of the Chamber included many republicans whose opinions were only two months old. Surprised by the events of February and called upon at every moment to discharge the responsibilities of sovereignty, Universal Suffrage seemed to lose confidence in itself and to wish to restore the ancient principles of authority, discredited and defeated though they were, in order to lean 


\section{The Revolution of 1848}

on them for support and countenance, instead of supplanting, them as ruler of the world.

This perplexity on the part of the new sovereign authority was not in itself surprising; it is easy to explain, but it was the beginning of a very dangerous crisis. The partisans of the old forms of government were delighted and took courage, observing with justice that the will of the people, which had been declared by the Revolution to be sovereign on earth, was not so averse to their own views as many had feared would be the case. On the other hand the moré ardent revolutionaries, the advanced republicans and the Socialists, were depressed. They asked themselves whether Universal Suffrage, which had been crowned by the Revolution, could deny its master, lie to the people, and threaten the Republic.

Discord and suspicion between the parties began, and grew so rapidly that, on the $5^{\text {th }}$ of May, eleven days after the meeting of the Assembly, the first crisis of the new régime broke out. It was grave in itself and still more grave in view of the reason or pretext which gave rise to it. On March 6th, Lamartine had obtained the Provisional Government's approval of a manifesto to French diplomatic agents in which it was declared that the new Republic threatened no 
power, that it did not regard monarchism and republicanism as "absolute principles always at war with each other," that "the treaties of I8I 5 no longer existed in law for the Republic, but that it recognized de facto the territorial delimitations laid down by these treaties." This subtle distinction between law and fact was intended to reconcile the legitimate anxiety not to involve the young Republic in dangerous and dubious adventures with the traditions of the first Revolution which had dared to defy Europe and had called upon its peoples to vindicate their liberties.

In March and April, however, after so much of Europe had taken fire, it became more difficult for the Government to reconcile these two irreconcilable positions. Events in Italy had deeply moved France-evoking memories of the Cisalpine Republic and the Kingdom of Italy, and of the trophies won by the armies of the First Republic fighting against the House of Austria in the Valley of the Po. At the same time the national sympathy with Poland, which had never died out, was rekindled most of all in the parties, chiefly advanced republican and socialist, which were readiest to accuse the new government of betraying the Republic and the Revolution, and were demand- 


\section{The Revolution of 1848}

ing the organization of labour and the abolition of poverty. Their revolutionary tradition, their hatred of tyranny and oppression, their desire to embarrass the monarchical parties, which were less zealous in these causes, explain the fervour which they displayed.

But the Government were in the position that the very people who blamed them for not carrying out a social revolution were urging them to attempt intervention in international affairs which would have brought about a war of the first magnitude. They endeavoured to extricate themselves from this dilemma by the affirmation of general principles. It was true that France should put herself at the head of a federation of free peoples. The treaties of 1815 were dead. But it was not the duty of France to revise them unaided, and she should wait for a European conference which would meet in the distant future. This expedient lasted until May I5th, when a procession of workmen, led by Blanqui, came to present a petition to the National Assembly in favour of the unfortunate Polish nation with cries of Vive la Pologne! Vivela Republique! The procession invaded the Palais Bourbon, penetrated into the Chamber, ordered the deputies to threaten Austria, Russia, and Prussia with war if they did not 
immediately deliver Poland from her chains, and finally declared the Assembly dissolved!

After a few hours of fisticuffs and vociferation in the Parliamentary precincts the disturbance was easily and bloodlessly quelled, since the National Guard responded at once to the summons of the Government to restore order. Yet this revolt of the people of Paris against Universal Suffrage, which three months before they had themselves proclaimed as the Sovereign of the State and the source of legitimate authority, profoundly disturbed both France and her new Republic. Many began to wonder whether the people, having acquired the right to command, had not forgotten the duty to obey. And, while the Assembly on May 24th declared the desirability of a fraternal agreement with Germany, the independence of Poland, and the liberation of Italy, the revolt of May I 5 th discredited the doctrine of intervention with all parties who were on the side of order, and thus countersigned the treaties of 1815 by confirming so much of them as was still in force.

The difficulties of the situation were increased by the debates of the Germanic Parliament which, as we have seen, met on May I8th. That Parliament at once proclaimed its right and duty to restore the Germanic Empire. After having 
in vain offered the crown to the King of Prussia, the title of Vicar of the Empire was tendered to the Archduke John, the most popular of the Hapsburgs, and, as its ranks were packed with conservatives and monarchists rather than with radicals and revolutionaries, it soon showed great animosity against France and declared that German unity should embrace on the one hand the Duchy of Posen and on the other Trieste and even Venice!

While in France Universal Suffrage was offering Germany brotherly affection and was demanding independence for Poland and freedom for Italy, Universal Suffrage in Germany replied by declaring its hatred for France, by robbing Poland of Posen and Italy of Venice, and by paying court to Prussia and Austria, which, though in different ways, were fighting the Revolution with equal determination. The Revolution could not compose the discords of Europe if those who wished to tear up the treaties of 1815 , in order to restore their own property to the peoples these treaties had despoiled, also wished to tear them up in order to increase their own booty. This was a salutary warning to France, but, absorbed as she was in her own internal troubles, she could not take advantage of it. The heads of the working 
classes had been turned by the flatteries of which they had been the object since their victory in February, by the promises which had been made to them, and by all the new doctrines of the day. At the same time they had been impoverished by the disturbance of commerce and industry, and this aggravated the disappointment of many illfounded hopes. Revolutionary agitators therefore broke loose from books, ceased to be academic, and harangued the workmen in the squares and streets or put themselves at the head of demonstrations demanding the abolition of competition and usury, the nationalization of banks and railways, free loans, and trades unions, the right to work, a Ministry of Progress. Societies, secret and other, were very active among the people and for some time had been causing suspicion and anxiety to the upper and middle classes. The disturbance of May I5th had increased both these feelings, and demands began to be heard for vigorous counter-measures. The party which had founded the Republic, and which was now to give it a stable form, was divided into two groups of which one was inclined to a reconciliation with the old monarchist parties in the interests of order, while the other wished to forgive the multitude its impatience and its violence in order that the 


\section{The Revolution of 1848}

Second Republic might not be betrayed like the first.

Rancour and party spirit complicated the agitation, and embittered and intensified these differences of opinion. The Bonapartist faction, which had recovered from the humiliation which it had so long endured under the two preceding régimes, took a leading part in the conflict, and the Socialists became the object of an implacable animosity on the part of the upper classes and the bourgeoisie. On their side the Parisian working-class, who had been told so often that they were the authors of the revolution of February, were offended by the suspicions of their intentions and those of their party which were felt not only by the partisan of the former discredited governments but also by the republicans of recent date. They were embittered by the poverty which Universal Suffrage had not succeeded in abolishing, by the disappointment of so many of their hopes, and by the persecution of their leaders. They were ready, therefore, to lend an ear to the extremists, to the hot-headed fanatics of revolution, even to Socialist and Bonapartist intriguers, who kept on repeating that the Revolution had been betrayed by the National Assembly, that the people of Paris who had founded the Re- 
public must take arms again, and, in fact, that they should rebel against Universal Suffrage. The result was that the Parisian proletariat did actually rise in rebellion on June $23 d$ to the tragic cry, "Du pain ou du plomb!"

No impartial writer will deny the Parisian workmen of 1848 the praise which courage, self-sacrifice, sincerity, and an ardent desire for good deserve, whenever these virtues succeed in piercing the hard crust of the earth amid the tangled thicket of the selfishness and the evil passions of the world. These humble workmen had felt from the bottom of their hearts the full force of the tragedy which had come to pass in Europe when the old qualitative civilization had passed away, leaving a new quantitative civilization in its place. They had not reached the point of demanding the blessings of peace and plenty, but were ready to suffer and to die in order that the world might be purified and, in the abyss of their poverty, they were moved by the misfortunes of Poland and of Italy. They belonged, in fact, to that part of the human race whose virtues compensate for the vices of the rest and entitle them to all respect. Seldom, however, have high-minded men so tragically shed their blood for the ruin of all that it most concerned them to 


\section{The Revolution of 1848}

preserve. This time the Army and the National Guard showed no hesitation, and the common danger united the educated and the middle classes. Thus, after three days of very bitter fighting, the insurrection was quelled, and the élan, the confidence, and the moral force of the Revolution which had seemed destined to renovate Europe from Paris were shattered for ever.

The executive commission had been compelled to resign even before the insurrection was over, and General Cavaignac, the Minister of War, had been made Dictator and ruled in its place at the head of the Republic. Four months after it had been proclaimed Sovereign by the Revolution, Universal Suffrage had yielded up its powers, temporarily it is true, to the military authorities for fear of Revolution. It was an even more bitter disappointment that, after this insurrection, there also revived among the upper and middle classes all the old terror of republicanism, of Universal Suffrage, and of popular sovereignty which the victories and the sublime principles of the Revolution had lulled to sleep in so many minds. France was once more tormented by doubts which persisted for half a century as to whether, after all, it was not chimerical to seek any other sources of legitimate authority than 
those to which mankind had for centuries been accustomed. Hence arose perplexities and hesitations, a revival of courage among the ancient enemies, and a further cooling of the new friends of progress, which little by little weakened and undermined the Republic until they finally caused its ruin.

Many historians blame the bourgeoisie and the upper classes of France for having been too easily frightened by this insurrection, while others are inclined to suspect that their terrors were, in part at least, purposely exaggerated. But the recent disasters in Russia show that there was good reason for alarm. However repugnant it may be to compare the vile gang of which Lenine is the head to the high-minded rebels of June, I848, it is none the less true that Lenine and his followers have accomplished what these rebels tried in vain to do -namely the forcible overthrow of the first legal authorities established by the Revolution, the Provisional Government and the Constituent Assembly, whose purpose was to give the new régime the sanction of definitive legality and to impress upon it the indelible character of legitimate government. What would have happened if the insurgents of June had succeeded-as Lenine has done-in striking down by a coup de main every 


\section{The Revolution of 1848}

principle of legality? Would not France, like Russia, have fallen a victim to force which has no title to authority beyond itself and which is compelled to sustain itself by ever growing and ever more wicked violence, until it bleeds itself to death or is suppressed by foreign intervention? The fiery test of successful revolution has always been its capacity for calling a halt once it has overcome the old principle of legality, for not acquiring a taste for the game, and for re-establishing order as soon as possible. The Revolution of I 848 failed under this ordeal.

This was a great misfortune, for the terror aroused in France by the second civil war, which broke out four months after the first, precipitated the complete ruin of the Revolution, and by this ruin, as we shall see, Germany alone was the gainer. In a certain sense we may truly say that the events of June were the first great stroke of luck for Germanism, which was quietly awaiting its hour.

All these consequences, however, were not apparent until later. For the moment the insurrection of June inspired the parties of the old régime with new courage. If such were the bloody fruits of liberty-! While in France the Revolution had turned its own weapons, with disastrous 
results, against itself, it was struck down in Italy by the arms of its enemies. Marshal Radetzky had not been slow to profit by the respite afforded by the slow progress of the Piedmontese forces to summon reinforcements and regroup his army. In July, after reconquering all Venetia except Venice itself, he moved against the army of Carlo Alberto with overwhelming forces and drove him back, step by step, to the Ticino, compelling the King to conclude an armistice on August 9 th, whereby he undertook to recross his frontiers.

The Revolution had thus undergone a serious, but not an irreparable, defeat in Italy. The Austrian Empire, in fact, notwithstanding its Italian successes, seemed every day in greater danger. The Court had fled to Innsbruck, and, when Parliament met at Vienna on July 22d with the powers and duties of a Constituent Assembly, perilous difficulties arose with Hungary. Hungary regarded Croatia as one of her own provinces and refused to recognize Jellachich as Ban or any act of the National Committee. On the other hand the Austrian Government declined to accept the views of Hungary on this point. The Hungarian Parliament retorted in July by deciding to prepare an army. It was there- 
fore to be expected that a War of Secession would soon break out between Austria and Hungary.

In these circumstances prompt assistance from France might perhaps have saved Italy. Such assistance was in fact asked for, both by Carlo Alberto and by deputations from the Italian cities, but the Government of General Cavaignac hesitated. One party in the Ministry was disposed to help Italy, considering that the time had come when the treaties of 1815 should be finally torn up. Another party opposed this policy from fear of the consequences. To increase the perplexity of the moment England, suspecting that France would strengthen herself by liberating Italy, intervened with the proposal that France and England should jointly interpose as mediators between Austria and Piedmont, though the course of events showed clearly that what was required was not to attempt a bargain but to strike a final blow at the wounded giant in order that Italy might be free. About the end of September war broke out between Austria and Hungary, and in October the Revolution got the upper hand in Vienna. The populace, which was on the side of Hungary, revolted in order to prevent troops being sent to fight against the Hungarians. The 
Court had to fly to Olmütz, while the rebels remained in possession of the capital.

If in the autumn of 1848 , a French army had set out for Piedmont by the Valley of the Po, it is not easy to see how Austria could have retained the booty she had secured in 1815. But the French Government, weakened by the grave internal crisis, and doubtful of its own security, allowed itself in the end to be overpersuaded by England, who provided an excuse for avoiding a dangerous enterprise. Thus Austria gained time to await a change of fortune, and was once more saved by the precise but small-minded calculations of England and the hesitations of France where the Revolution had now begun to doubt itself. Its doubts were so serious that the National Assembly decided by 827 votes against $\mathrm{I} 30$ that the President of the Republic should be elected not by itself, but by Universal Suffrage-so strong was the desire for a powerful executive force which would make the Republic as like a monarchy as possible. Universal Suffrage was to be applied, like a miraculous chrism wherewith to anoint as Head of the State a Dictator, a half-sovereign, a President in whom the multitude might recognize the successor of their ancient monarchs.

But when Revolution stumbled in France how 
could it prevail in the other states of Europe? The revival of the parties and the institutions of the old régime began from the autumn of 1848 . At Frankfort the Radical party attempted a revolt when the Parliament approved the seven months' armistice concluded by the King of Prussia with Denmark, denouncing it as a betrayal of the national cause. But the revolt was repressed not without bloodshed. In Austria General Windischgratz marched on Vienna with fifty thousand men, and after a bombardment, conquered the city. Shortly afterwards the Emperor Ferdinand was forced by the absolutist party to abdicate, as being too weak in the struggle against Revolution. He was succeeded on December $2 \mathrm{~d}$ by Francis Joseph, his grandson, a youth of eighteen in whose hands the destinies of Austria were condemned to remain for two generations.

In Italy the absolutist and Austrian party had raised its head again and was intriguing with the object of forcing Piedmont and other Italian Governments compromised by the Revolution to conclude a shameful capitulation. In France, finally, on December Ioth, Universal Suffrage elected as President of the Republic Louis Napoleon Bonaparte, son of Queen Hortense. Of 
the $7,326,345$ votes cast, $5,434,226$ were for this nephew of the great emperor, I,448, 107 for General Cavaignac, the few remaining ones being dispersed between Ledru-Rollin, Raspail, and Lamartine.

The meaning of this election was clear enough. While the Assembly a few months earlier had entrusted Universal Suffrage with the task of arming the Republic with a strong executive power, now Universal Suffrage had restored the credit of the old legitimacy and had turned to the last of the former systems of authority which still survived unimpaired by the civil struggles which the existing generation still remembered. It had selected as President of the Republic the man who in all France most resembled a monarch. The hat and sword of Napoleon had been taken out of the museum, and Universal Suffrage hoped that, concealed behind these relics, it would be better obeyed.

Shortly afterwards, in March, I849, the Frankfort Parliament, which had settled the imperial constitution after much difficulty, elected the King of Prussia Emperor of Germany by 290 votes against 248 abstentions. In Germany also Universal Suffrage was rallying to the sword and the sceptre. This led to nothing, however, for Austria recalled her representatives from the 


\section{The Revolution of 1848}

Parliament and declared it dissolved. Prussia, whose King declined to receive even an imperial crown from the hands of Universal Suffrage, followed Austria's example, and invited the German States to send their representatives to Berlin to study a new constitution. Everywhere the party of Divine Right was regaining credit. In Hungary the revolted nation in arms still held out, while in Italy the revolutionary party despaired of French assistance, and the good sense which helps only those who are not altogether abandoned by fortune gave way to the wrath which will rather sacrifice itself without hope than admit its impotence by capitulation. Towards the end of 1848 , terrified by the violence of the nations and powerless to control the war party, the Pope fled from Rome. A little later the Grand Duke of Tuscany fled also. A Provisional Government was set up at Florence and, after some hesitation, on February 5, I849, a Republic was proclaimed at Rome.

A Republic had re-arisen in the city which in a distant and fabulous past had been first the tiny cradle of republicanism and afterwards the grandiose mausoleum of its ruins! Already mortally wounded in its duel with the Austrian Empire, the Revolution refused to surrender in Italy and 
gathered its forces for one of its boldest strokes. But in this critical determination what a defiance to the whole Catholic world was implied! As Massimo d'Azeglio afterwards pointed out, the Pope had a double character. For the Italians he was a petty sovereign in the Peninsula, a hostage of Austria; for foreigners he was the Vicar of Christ and the Head of the Church. If in Italian eyes the conquest of the Holy City was merely an operation in a war against clericalism, it was for other peoples a mortal affront to the Catholic Faith. No human power, then or afterwards, could clear up this tragic misunderstanding between Italy and the Catholic world. No sooner was the Republic proclaimed at Rome than a new enemy took the field against the Italian Revolution already at grips with Austria, and this enemy was none other than France herself.

France which, only a year previously, had risen to break the chains of the world, which in the Autumn of 1848 had deliberated whether to send an expedition to the help of Italy, in 1849 sent a force to compel her younger sister the Roman Republic to restore her precious conquest to the Pope! The conservative classes, including the French party which remained faithful to the 


\section{The Revolution of 1848}

Church, owing to their birth and social position, had much influence with the new President. The principles of traditional authority had now recovered their credit with the more influential classes which had been impoverished by the Revolution, and they were inclined to support the institutions which had been their historic organs. It is easy to understand why Louis Napoleon wished to forbid the Revolution taking possession of the Holy City.

France was not alone. Another power, Russia, soon intervened. Though all Europe had vacillated, Nicholas I. had stood firm. He had condemned Carlo Alberto as a traitor and had disbanded the regiment known by his name. $\mathrm{He}$ had also shown some resentment against the King of Prussia for his weakness. Francis Joseph, who had ascended the throne of the Hapsburgs with the determination to restore absolutism, asked and obtained the aid of Russia against the Revolution. Nicholas I. did a thing which is almost unique in European history: merely because of dynastic and political solidarity, when no other interest was involved, he sent a large army against the Hungarians and definitely saved Austria. The hopes which the Italian Revolution had of Hungary were also dashed to the ground. 
How could Italy and Hungary conquer France, Austria, and Russia? What remained but to die?

Destiny fulfilled itself. On March 2I, I849, Carlo Alberto broke the armistice because he had lost all hope of victory. The war was short. On March 23d the Piedmontese army was overcome at Novara by overwhelming forces and the same evening Carlo Alberto abdicated. Once more force had triumphed. After the fall of Piedmont neither Sicily nor Venice nor the Roman Republic could continue the fight. In the second half of 1849 Italy seemed to have returned to the condition from which she had striven to rise

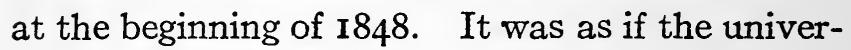
sal Revolution had come to nothing.

Nor was this the case in Italy alone. In Germany the declarations of Austria and Prussia that the Frankfort Parliament was dissolved had given rise to grave disturbances, particularly at Dresden, in Bavaria, and in Baden. These outbreaks, however, were quelled, and the Parliament, which had been reduced to a handful of members by the departure of the Austrians and the Prussians, was compelled to retire to Stuttgart, where, on June 18, I849, it was dispersed by the soldiers of the King of Württemberg.

In Austria, as early as March, when the issue 


\section{The Revolution of 1848}

of the war both in Hungary and Italy was still doubtful, the young Emperor had been bold enough to dissolve the Constituent Parliament, granting as a compensation the so-called constitution of March. But, after the reconquest of Venice and Lombardy, and after Hungary had been subdued with the help of Russia's absolutism, he gradually withdrew the concessions which had been made until, on December 3I, I850, the instrument known as the Patent of S. Silvester revoked even the constitution of March. The King of Prussia did not perjure himself so openly as the Emperor of Austria had done. $\mathrm{He}$ and his government, by patient manœuvring during 1849 or 1850 , found means to induce the first Parliament elected by Universal Suffrage to pass the constitution which is still in force in Prussia. That constitution by means of its Parliament provides an oratorical safety valve for the educated bourgeoisie; but a complicated system of franchise on a timocratic basis secures the privileges of the Crown and of the aristocracy, and keeps the government of the State in the hands of the dynasty and of the nobility. In 185I, after many struggles and negotiations between Austria, Prussia, and the other German States, the old Diet of the Germanic Confederation was finally restored. 
While in Italy Revolution had been conquered by foreign intervention, and in Austria by the Court and the Army, in Prussia it had been evaded. In France, on the other hand, it committed suicide. In the course of two years the National Assembly and the Government of the Republic abdicated their authority, not merely by the contradictions, the hesitancy, and the impotence which they displayed, but also by their persistent suspicion of Universal Suffrage and their constant attempts to restrict the application of the principle by surreptitious expedients. The nation lost patience; the adversaries of Universal Suffrage were not idle; its supporters were incensed. Among the people there was a great increase in the number of open and secret societies, and a hope spread that in 1852 there would be great changes in the world.

The upper classes demanded a government whose indisputable title to authority should be force, though it was not easy to see how their desire could be satisfied in the midst of the innumerable quarrels of the upper classes themselves and the implacable conflict of so many political views and principles of authority. To the mêleee of legitimists, Orleanists, and the republicans were now added the socialists and the Bonapartists, the last-named being emboldened by the circum- 


\section{The Revolution of 1848}

stance that a Bonaparte was once more at the head of the Republic. Many were beginning to despair when Louis Napoleon found a means of his own, which was at once bold and specious, for dealing with the apparently insoluble problem. $\mathrm{He}$ took advantage of the universal discontent and the anxieties of the upper classes to dissolve the Assembly and assume the Dictatorship. He re-established Universal Suffrage on December 2oth, adding a plebiscite in the following terms:

Le peuple veut le maintien de l'autorité de Louis $\mathrm{Na}$ poléon Bonaparte, et lui délégué le pouvoir nécessaire pour faire une constitution sur les bases proposées par la proclamation du 2 Décembre.

In that proclamation he announced his intention of restoring "the government of the first consulate" with a responsible Head elected for ten years, Ministers dependent on the executive, a Council of State which would prepare legislation and present it to the Corps Législatif, which, in its turn, would be elected by Universal Suffrage, and would debate and pass laws. There was to be a Second Chamber composed of the most eminent men in France, who would be responsible for the observance of the constitution and the maintenance of liberty.

What else was this constitution than a prison in 
which Universal Suffrage was to be held in bondage by a President invested with the powers of a dictator? And yet 7,439,216 citizens voted for it and only 640,737 against it. Universal Suffrage, after governing France for three years, had surrendered itself a prisoner to a Bonaparte. The promised constitution was hastily drawn up and Louis Napoleon seized all the sovereign powers for himself, leaving to Universal Suffrage only the right to elect the Corps Législatif, which could only pass such measures as were proposed to it by the Council of State. It had no right to insist on amendments which the Council of State rejected, to nominate its own President, or even to question Ministers, who, being responsible to the President of the Republic, could not appear before the Corps Législatif. A decree of February I7, 1852, which abolished the liberty of the press, completed the work.

Thus, at the beginning of 1852 , the history of the Revolution might well suggest to the contemporary spectator the brief splendour of an Aurora Borealis which had flamed across the firmament of Europe but whose passing glories were now drowned in a night which was darker than ever. The peoples whom it had incited to recover their national independence-Bohemia, Hungary, and Italy- 


\section{The Revolution of $\mathrm{I} 848$}

were all once more in chains. What had been the result of its attempt to crown the Will of the People sovereign of the world? A timid constitution in Piedmont, an equivocal and insincere constitution in Prussia, a republican dictatorship in France, less oligarchical perhaps, but more despotic than the monarchy of Louis Philippe. Even this, towards the end of 1853 , was changed into an empire when Louis Napoleon assumed the imperial crown with the style of Napoleon III. France had turned her back, alike on legitimate monarchy and on the principles of 1848 , and was seeking the principle of authority in the tradition of the Empire whose titles to government were not principles or parchment deeds but genius, glory, and good fortune.

All this, however, was not reality but mere appearance. The great change had in fact come, and from it derives the whole history of Europe until the outbreak of the world war. 


\section{CHAPTER V}

THE GREAT SURPRISE. THE GERMANIC TRIUMPH (I848-I870)

THE Revolution of $\mathbf{I} 848$ seemed at the time to have failed in every country in which it had broken out, yet it did achieve a few partial successes. In the first place, it split the dynasties of Europe into two groups, those which had bargained with Revolution, that is, Prussia and Piedmont, and those which had stood fast-Russia, Austria, and the Italian States apart from Piedmont. Secondly, it set up between these two groups of legitimate dynasties the dynasty of the Napoleonidæ which suddenly reappeared on the débris of $18 \mathrm{I} 5$, a creature of the Revolution and an intruder in the august family of sovereigns by the Grace of God. While not openly at war, the two legitimate groups began to distrust each other, and the new Napoleon who had been crowned at Paris was viewed with anxiety and suspicion by both. The King of Prussia called him "the crowned adventurer," and accused him of having a 


\section{The Germanic Triumph}

secret understanding with Kossuth and Mazzini for carrying fire and sword into the four corners of Europe. In his letters Nicholas I. did not address him as "Brother," as he did other sovereigns, and when Napoleon III. remonstrated, excused himself by the remark that brothers were given by God, whereas a man chose his friends for himself! Though Europe had been freed from none of the tyrannies, real or imaginary, which the contemporary generation hated and wished to slay, the conspiracy of the Courts to impose absolutism on the peoples was broken, and the first league of European states had been dissolved.

How and why this happened is now clear. The first European peace league failed because the doctrine of Divine Right and legitimacy had for the greater part of the continent ceased to be anything but an imposture practised by interested parties. It failed because it had ruthlessly sacrificed several peoples, among others Italy, the firstborn of European civilization. It failed, finally, because it had refused to recognize any of the legitimate ambitions and aspirations of the middle class. But, once the concord of Courts was broken, great cracks and crevices opened in the crust which for thirty years had contained the fiery mass which since the Revolution and the Empire had been 
boiling in the heart of the European polity. Tongues of flame, geysers, jets of lava, and burning ashes began to shoot forth from these cracks and crevices, opening and enlarging the way for a more violent eruption, until finally the outburst came which lasted for four years and threatened to bury the civilization of Europe under a winding sheet of ashes like an immense Pompeii. The first gust of flame which lashed Europe was a war about Eastern affairs.

The responsible author of this war was no other than the Head of the Holy Alliance, Nicholas I., so great was the power of the Revolution of 1848 over those who hated it the most! It appears that Nicholas had cherished all his life a great ambition to conquer Constantinople and to annihilate Turkey. However, so long as the crowned heads of Europe had lived in unity and concord like a large family he had scrupled to disturb this happy state of affairs by his ambitious plans. He had, therefore, resisted the temptation until the Revolution of 1848 seemed to offer a favourable opportunity of accomplishing his schemes of conquest with the acquiescence and complicity of Europe. From Austria, whom he had saved and whose youthful sovereign had humbly kissed his hand, Nicholas I. believed himself to be safe. He was 


\section{The Germanic Triumph}

still all powerful in the German Courts, notwithstanding a certain coolness with the King of Prussia. In England his old friend, Lord Aberdeen, who was faithful to the traditions of the Holy Alliance, was in office. What could France have done alone? That England and France, now that a member of the dynasty of Napoleon had assumed the crown, could unite against Russia appeared to him impossible and he said so to several people.

These delusive calculations appear to have induced Nicholas to raise in the first place a question about the Holy Places and then to enlarge his pretensions by degrees until he actually claimed from Turkey a protectorate over all Greeks who were subjects of the Ottoman Empire. At this point, however, that which according to Nicholas was impossible happened, and France and England joined hands. Although neither of these Powers wished to undertake a war Nicholas's enterprise endangered so many interests which they had in common that the former rivals were gradually led to make a joint effort to persiade Russia both by arguments and threats to desist. When the Czar saw that France and England presented a united front he hesitated, but he was no longer able to control events. Turkey had grasped the fact that the old agreement of the European Courts was 
broken and that an opportunity had presented itself of making war with Russia with the blood and treasure of France and England which would not soon occur again. She therefore manœuvred so skilfully that all approaches to agreement failed when they were on the point of succeeding, and France and England took the field in her defence.

The Crimean War, after the Italian war of $\mathbf{r} 848$, takes the second place in the new series of conflicts beginning in 1848 , the war in Hungary being rather of the nature of a civil struggle, while the war for Holstein between the Germanic Confederation and Denmark was little more than a skirmish. The cause of the Crimean War was the determination to prevent Russia from aggrandizing herself too much in the East to the prejudice of Turkey. England and France were not alone in allying themselves with Turkey to bar Russia's way to Constantinople. They were joined by Piedmont-the small State which had first dared to break the peace of the sovereigns by defying the Hapsburgs in 1848. She now asked, as an honour, to be allowed to offer her soldiers, though she had no interests in the East and should have been more concerned with her own uncertain and precarious destinies than with the fate of Constantinople. This intervention, which seemed madness to many 


\section{The Germanic Triumph}

contemporaries, but which was part of the deeplaid plan of a profound and subtle diplomatist exalted by a mighty ambition, is the clearest proof of the internal revolution which had taken place in 1848 , in spite of the apparently unaltered aspect of many things which, after a brief period of perturbation, had returned to their old form and shape.

Piedmont had, indeed, been beaten and confined by Austria within her old boundaries, but she had not been reduced to the old subject status as a client and protected country, like the other governments of Italy. These governments, once more persuaded of their invincibility, thanks to the support of Austria now victorious over the Revolution, had recommenced their evil practices and were behaving worse than ever. Except in Tuscany, liberalism and nationalism were persecuted. Obsequious servility to themselves, to the Church, and to their powerful protector was enforced by corruption and terrorism. Every impediment which suspicion could devise was placed in the way of the nation's studying, enriching itself, working, or copying the innovations with which England, France, and Germany were experimenting in trade and industry.

Once more Italy had been bound to the corpse of her own past and once more there commenced 
a series of clandestine agitations, secret societies, conspiracies, and risings. In the Kingdom of Piedmont, on the other hand, owing to the grant of the Constitution, the war against Austria, the abdication of Carlo Alberto, a definitive change had taken place between $\mathrm{r} 848$ and I849. The greater part of the aristocracy who had been faithful servants of absolutism under the three Kings of the Restoration and who had followed Carlo Alberto in his warlike adventure more from obedience than conviction, had retired to their Estates. The new King, Victor Emanuel II., had clearly understood that the old order had gone for ever in Piedmont and had set himself to govern with parliamentary institutions, that is to say, with the help of the educated middle class and of such of the nobility as did not wish to separate themselves from the new age, and, so far as was possible, in the spirit and with the aims of the Revolution of 1848 , which was to a great extent the work of the bourgeoisie.

In a few years Piedmont became unrecognizable by comparison with the other States of Italy. In them absolutism ruled with the support of the aristocracy while in Piedmont the King governed according to the Constitution; bourgeois and aristocrat, distinguished only by an empty title, were mingled in Parliament and in office; the press was 
free. In the rest of Italy the State did everything in its power to cherish the Church and enforce respect for it. In Piedmont every opportunity of quarrelling with Rome was 'seized, in order to give vent to the feelings of anger and rancour of the liberal parties and the new classes which had been taken into the government. In the rest of Italy every new piece of industrial machinery, every'new invention of science, every new teaching of philosophy, was regarded with suspicion, whereas in Piedmont nothing was neglected which could conduce to the economic and scientific progress of the world. The other States of Italy were faithful satellites of Austria, but the new Piedmontese Government scarcely hid under a show of courteous independence its aversion to the Empire by which it had been humiliated at Novara. The Hapsburgs had been able to reconquer Milan, Venice, and the hegemony of Italy; but in Piedmont they had lost for ever the small but precious ally who from I 8 I 5 to 1848 had barred the Western Alps to France.

In short, in the tempestuous years 1848 and 1849, the Italian Question, which had hitherto been nebulous and confused, had taken the vivid and definite form of a great civil war, latent throughout the peninsula between two parties, 
one of which wished to preserve the order of things established by the Congress of Vienna, the respect for Divine Right, absolute government, and aristocratic privilege, which was opposed to all the novelties of the century and particularly to the progress which the Liberals admired so much, while the other longed for representative institutions, the abolition of aristocratic privileges, the humiliation of the Church, and the introduction into the cities of that confused cult of progress and Fire which led men to worship the machines made by their hands. The first of these two parties leaned for support on Austria, and as Austria from the Valley of the Po held the whole peninsula in the hollow of her hand, her predominance was not to be gainsaid. The second party ruled Piedmont and was the hope of all those who were oppressed by the dominant party in the other States. Refugees from all parts of Italy now fled in thousands to Turin. How could this civil war latent in the breast of Italy be decided except by a new war between Piedmont and Austria? And what would become of the little State if at the terrible moment in which she must again confront the giant she lacked a strong ally?

Thus the war in the East seemed to Cavour and to Victor Emanuel a favourable opportunity of ad- 
vertising themselves in the midst of the reviving discords of the Great Powers. In these discords lay Italy's only hope of emerging from her present misery into a better life. Russia had saved Austria in 1849 by intervening in Hungary and thus completing the ruin of Piedmont. Russia, like Austria, was an absolute monarchy, and Nicholas I. was the champion of Divine Right who had declared Carlo Alberto to be a felon for granting a constitution. The choice was soon made. The nobility and the remains of the old conservative party tenaciously opposed the intervention of Piedmont, and quite rightly from their point of view, for the Crimean War was the grave of the Holy Alliance. Not only did the death of Nicholas I., which took place during the campaign, deprive the absolutist party of its most authoritative head, but his son and successor, Alexander II., was a man of a different temperament and different inclinations. Under the new Czar in the Russian Court and Government the feeling of solidarity with the dynasties which had remained faithful to absolutism was overcome by a bitter resentment against the Hapsburg Monarchy which had repaid Russia for her help in Hungary by observing during the Crimean War a suspicious and at times a malevolent neutrality. 
The Crimean War estranged Russia and Austria, the two empires which should have sustained in Europe the doctrines and the traditions of the Holy Alliance, and, after that estrangement, what remained of the old league of monarchs? Europe was now emancipated from its control and mistress of her own fate, of her discords, rivalries, and ambitions open or secret. England again retired into her shell to prosecute her ever-growing commercial successes and regarded Continental affairs strictly from the point of view of profit and loss. Russia retired into her immense spaces to recover from the wounds made by the war, to brood over her resentment against Austria, and to prepare for the great reforms which were to abolish servitude and to open the way for the middle classes to higher education and public office. Austria was watching on the outskirts of her empire her enemies, who had been beaten but not subdued. Prussia continued to administer her scattered territories with zealous energy and to dream her turbid dreams of power and glory while she put her new constitution into operation.

There remained France. In the midst of the reviving discord of the Powers, when each was somewhat surprised and rather dêsorienté at being left alone after so many years of mutual support, 


\section{The Germanic Triumph}

France found herself less constrained, freer in her movements, and in a position to exercise a certain authority. Had not the long agreement of the Courts perhaps been arranged for the special purpose of preventing France from moving and agitating too much? Once the chain was broken France no longer found all Europe united against her, by a common suspicion if not by a common hatred of herself, but a series of States each dominated by its own passions and interests, among whom, thanks to her prestige and her resources, she could, at least to a certain extent, take the lead.

After the Crimean War, in fact, partly owing to his name, partly to the victory of the French arms, partly to the reserve or remissness of all the other Powers, Napoleon III. enjoyed a very special authority in Europe. The alliance with England had been followed by a cordial friendship between the two nations. Russia from resentment against Austria tried to make friends with France. Even between France and Prussia there were good relations. The King of Sardinia cultivated with growing zeal the friendship of the new Empire in the Italian Peninsula. France might therefore have acquired in Europe a moderating and regulating authority not unlike a real primacy-but 
on one condition, namely, that the nation was in agreement as to the policy to be followed and prepared to undergo the necessary sacrifices, and that the government should pursue that policy with energy and intelligence. But France, as we shall see, was far from agreement and the government was now confounded with the will of the sovereign.

Napoleon III. was not a small man; he had genius; he had ideas larger and more profound than are possessed by the hacks of statesmanship. He understood men and knew how to manage them. He was animated by noble ambitions, and, while he remained in full health and vigour, he did not lack courage and resolution. While, however, he possessed neither the qualities nor the defects of a great tyrant, his ambition to reconquer for his family the crown of Napoleon I., the perturbation of the times, and a fear lest his own sovereign authority might not be regarded as legitimate, and consequently might not be respected by all, had led him to give the Republic and afterwards to retouch and transfer to the Empire a constitution which required a despot of genius as the Head of the State and times and circumstances favourable to such a Ruler's activities. 


\section{The Germanic Triumph}

This constitution was theoretically most ingenious, but it was wholly inspired by distrust of Parliamentarism and political liberty. It was calculated to defend the authority of a somewhat adventitious and improvised monarchy such as his against the darts of the press, the thunders of the tribune, and the spirit of criticism and revolt of great and small. But it also had the effect of isolating the monarch in a kind of fortress overlooked from all sides for it interposed between his authority and the great representative and administrative bodies of the Empire, which he should have ruled and turned to his advantage, so many privileges of a personal power which no one man could exercise that these bodies in great measure escaped from his control, remained independent, and withheld the collaboration which was indispensable. If the Head of the State had been a man of great energy, readiness, and authority, and, like the First Consul who ruled a State which was still simple, had been able to see everything with his own eyes and do everything with his own hands, the constitution might have been excellent. But by the middle of the nineteenth century, chiefly owing to the development of industry on the great scale, public affairs had greatly increased in volume and in complication, and, as we have seen, the 
nephew, though a man of no mean ability, had neither the virtues nor the vices which had led the credulous masses to revere the uncle as a demigod.

Thus he was in the position of having seized vast powers which he could only exercise to a very limited extent, and which instead of strengthening weakened his government, especially as the fear of revolution which had raised him to the throne began to pass away with the lapse of years. The Legitimists and the Orleanists began once more to regard him as a usurper and the Republicans execrated him as a traitor. It was in vain that Universal Suffrage, terror-stricken by the sceptre so suddenly offered, had tried to secure obedience by hiding itself behind the hat and sword of Napoleon! The new authority, which according to the letter of the constitution was so strong, seemed too Republican to the convinced monarchists who believed in Divine Right, too monarchical to the Republicans who believed in the Sovereignty of the People, and too authoritarian to the Liberals. Its legitimacy was therefore dubious in the eyes of all parties; it was tolerated, endured, and courted by all, but sincerely supported by none. In the days of its success it had many flatterers, and many who were ready to exploit its fortunes, but it found few faithful, 
capable, and sincere servants in its time of trouble. It raised hopes which could not be realized, and, as years passed, it became the victim of a growing weakness all the more dangerous because it could not be avowed for the very reason that it had been accepted and obeyed by the people in the firm belief that it was very strong. This was the reason why it could neither dominate nor profit by the tumultuous uncertainties of the situation in Europe which had been set free by the events of I848.

The war in Italy clearly proved this. This war was willed and had long been planned and maturely considered by Napoleon III. owing to certain views, both true and profound, which he held concerning the state of Europe and the tendency of the times. Europe in his opinion, since the scheme set up by the Congress of Vienna had fallen to pieces, required a new order. To create this new order it would be necessary to take more account in the future than in the past of the reawakened spirit of nationalism. It would be necessary to repeat for Italy the great victory of the treaties of 1815 , to satisfy certain of the legitimate ambitions of Germany, and to make some provision for the future of Poland. These ideas had been left in the minds of many by the Revolution of $x 848$. 
They were, it may be said, in the air, and they exalted the dynastic ambition of the nephew of Napoleon I., while they satisfied the longings of his somewhat visionary spirit.

How could he show himself more worthy of the name under which he had ascended the throne than by giving Europe the benefits of a more solid, more equitable, more liberal, and more fraternal order of things? But in order to rearrange Europe, beginning with a reconstitution of Italy, it was necessary to declare war on Austria - an enterprise which the friendship of Piedmont had now made possible and which had great attractions for the nephew of the great Napoleon. It would be a kind of dynastic vengeance for 1815, it would increase the authority of France in Italy, and at the same time, while liberating Italy from the hands of her executioner, would improve the general equilibrium of Europe. Precisely, however, because these views of Italian affairs were both broad and elevated, they were not accessible to all men, even in France, where, though there were parties capable of understanding them, there were other parties who wished for peace, feared war, and considered European questions from the narrow point of view of national profit. Moreover, if France was to make war on Austria as the ally of Piedmont, 


\section{The Germanic Triumph}

a pretext must be found which was not too much at variance with diplomatic tradition and the principles of international law as commonly understood. Napoleon III. could not say that he wanted to declare war on Austria in order to avenge Waterloo, to correct the injustice done to Italy by the Congress of Vienna, or to lay the foundation of a new Europe which would be more just and more enduring.

It is not surprising, therefore, that although he had long made up his mind to go to war and had come to an arrangement with Piedmont for waging it in alliance with her, Napoleon at the last moment, in the early days of 1859, was seized with one of those fits of perplexed hesitation which were destined so often to give cold shivers to Cavour. England was doing her very utmost at Paris, Vienna, Berlin, and St. Petersburg to prevent war, as were the peace parties in France. It was a case in which there were plenty of good reasons for making war but not the slightest pretext for declaring it.

Whoever re-reads today the history of the diplomatic manœuvres of those months will ask himself how Napoleon III. could possibly have effected his purpose of declaring war if he had not been favoured by the rancour of Russia and the 
anger of Austria. It was Russia who, out of irritation at what she considered the treason of Austria during the Crimean War, prevented the Powers from forming among themselves a coalition for the maintenance of peace by refusing to take part in any of England's efforts to secure that object. It was Austria that, by requiring Piedmont to dismiss her volunteers and to disarm, supplied Napoleon with the slight pretext which brought about the war for which there were such grave reasons. But were not these hesitations and perplexities, making doubtful at the last moment an enterprise which had been so long planned; was not this profound contrast between the motive and the pretext, the spirit and the form of the war, a proof that Napoleon was attempting something which was beyond his strength?

The discrepancy became more manifest as the campaign proceeded. Napoleon had crossed the Alps in order to drive Austria out of Italy and to unify Northern Italy under the sceptre of the House of Savoy, including part of the Legations in the new Kingdom. In Central Italy he intended to establish a monarchy which would include most of the States of the Church. The Kingdom of the two Sicilies was to be left in being and these three States were to be united in a Confederation 


\section{The Germanic Triumph}

under the presidency of the Pope, who was to retain Rome and a little neighbouring territory. Napoleon was opposed to complete unification, partly because he was afraid that a united Italy might be dangerous to France and partly because he feared that unification in Italy might be too powerful a stimulant for Germany. Moreover, not only Napoleon but all the Powers were so much against the unity of Italy that Cavour himself in the years before the war had set it aside as an unattainable dream. As, however, the allied armies, proceeding from one victory to another, drove back the Austrians towards the Quadrilateral, all Italy was stirred. The mere announcement that France and Piedmont had accepted Austria's challenge was enough to bring about a bioodless revolution at Florence, where the Grand Duke was forced to depart and the dictatorship offered to Victor Emanuel. After the Battle of Magenta the Duke of Parma and Modena fled, and on June IIth, when Austria withdrew her troops from Bologna and Ferrara, Romagna and the Marches also revolted and begged the King of Sardinia to assume the dictatorship.

The plan of reconstituting Italy as a Federation of national States would have been a very fine one had it not been for the fact that there was no raw 
material on which to work, that is to say, no States to federate, each of which was capable, at least to a certain extent, of subsisting by its own strength. The States of Italy had no indisputable historic title to existence; they were wanting in that prestige which a strong State knows how to earn by its achievements. They were detested by a rich and educated minority, and barely tolerated by the majority which obeyed only because they were compelled. They were, in fact, merely the disjecta membra of a nation which Austria had dressed out as Duchies, Archduchies, and Kingdoms and which the people overthrew and destroyed as soon as the bureaucracy had been forced to fly. None of them governed by its own strength, for all depended on the support of Austria, and either collapsed at once like Tuscany, Modena, and Parma, or tottered like the Papal States and the Kingdom of the two Sicilies as soon as Austria began to retreat in the Valley of the Po, abandoning her former protégés and allies. From one end of the peninsula to the other, in fact, the victories of the French and Piedmontese arms caused an explosion of the civil war which slumbered in the bosom of every State like lightning in a thundercloud. The absolutist and Austrian party which had been the oppressor for so many years felt its 


\section{The Germanic Triumph}

knees giving way with a sudden weakness, and tottered or actually fell at the first threat. The oppressed who formed the liberal, constitutional, and nationalist party rose and threatened their adversaries even when they did not succeed in overthrowing them.

Napoleon III. was not long in perceiving that every stroke of his army directed against Austria was shaking the old Italy of 1815 to its foundations, and he took alarm, for an Italian revolution was the very thing he did not want. Other anxieties also assailed him in the midst of his victoriesthe heavy casualties and the consequent effect on French public opinion, the discontent of the Catholic party at the revolution in the Papal States, and, not least, the news from Germany, for the Germanic Confederation and Prussia were beginning to take umbrage at the French victories in the Valley of the Po. Frightened by his own work and feeling that his hand was being forced, Napoleon broke off abruptly the enterprise he could no longer control. On July I Ith he met the Emperor of Austria at Villafranca and arrived at a peaceful understanding with him. Austria was to cede Lombardy to France who would transfer the province to the Kingdom of Sardinia. An Italian Federation would be constituted under the 
presidency of the Pope. A plan of reforms would be worked out for the States of the Church, and the Grand Duke of Tuscany and the Duke of Modena would be restored to their dominions.

This peace-a compromise between will and power, the will of a fine but somewhat visionary mind and the power of a parvenu and spurious emperor-plunged Italian affairs which it was intended to settle into a confusion which was even greater than that which had existed before the war. Some of the Italian States had overthrown their governments in order to join the Kingdom of Sardinia; others, the States of the Church and the Kingdom of Naples, more especially Sicily, were conspiring and revolting in order to do likewise. Such governments as had not already fallen were trembling in the consciousness that their days were numbered now that Austria was no longer there to support them, and they no longer knew to which Saint they should appeal for succour. Meanwhile the plenipotentiaries of the three belligerents met at Zurich in August in order to draw up and ratify the definitive Treaty which was to federate States which had either ceased to exist or were in imminent danger of disappearing, to restore to the Duke of Modena and the Grand Duke of Tuscany territories which one of the three 
parties to the Treaty, the King of Sardinia, already regarded as his own, and to propound reforms for the Papal States which for the most part were in open rebellion!

There were only two ways in which the Italian Question could be settled. Either a preponderating foreign power-France or Austria-would have to intervene again to settle things according to its own views, as in 1815 , or the two parties into which Italy was divided would have to be left to fight out the issue between themselves, so that the victor might establish a system that had some life in it. Austria, however, being now resigned to the loss of Lombardy, stood apart. She was delighted that France was perhaps more disconcerted by her victory than she would have been by a defeat and she contented herself with insisting that the agreements made by the impossible Peace of Villafranca should be carried out. Napoleon extricated himself as best he could. None of the Powers was willing to admit that the ancient order was at an end in Italy and that a breath of Revolution could now upset it finally at any time, and all persisted in trying to revivify what was dead and to kill what was alive.

The Italy imagined by Napoleon III. and approved by Europe was a heap of inanimate 
fragments, and it fell to pieces under the efforts made by its authors to set it going. Out of these dead and inarticulate fragments the Kingdom of Sardinia was to create a living organism capable of ruling itself and walking alone. How could this be done if not by collecting into a single State the States which after 1859 either had no government at all or a government on the point of collapsing? The unification of Italy was no product of precocious ambition but a necessity imposed by the gap left when Austria retired from the country after fifty-four years of predominance. Europe, however, would not hear reason, for Italian unity was terrible in its eyes. To secure it required all the audacity and the resourcefulness of a great statesman, fertile in the expedients, the intrigues, and the manœuvres of diplomacy. It was necessary to make more revolutions and more wars, to cede Nice and Savoy to France, and, in some cases of extreme necessity, even to break international law, for which the Great Powers were so solicitous when it secured them the tranquil enjoyment of their possessions, in order to deliver Italy from the almost desperate position to which she had been reduced by the hesitating intervention of Napoleon III. and the timid selfishness of Europe. 


\section{The Germanic Triumph}

The Power which first saw the necessity of recognizing Italian unity was England after Garibaldi's expedition to Sicily and Southern Italy. That expedition had been indeed a fiery ordeal for the old Italian governments which Europe wished to federate with the new. Among the expedients for extorting from Europe its consent to the inevitable, which was still obstinately refused, the Piedmontese Government had formed the plan of allowing General Garibaldi to attempt an expedition the ostensible object of which was to liberate Sicily, half of which was now in revolt. When, however, Garibaldi, with a thousand men, made himself master of Sicily, Crispi succeeded in persuading him to cross to the mainland, and, in a few months, after he had been joined by a few more thousands, the Bourbon régime fell because it had been abandoned both by the upper and by the educated classes and had lost all confidence in itself.

In a word the logic of events was more powerful than the schemes of men. On February 18, I86r, the first Italian Parliament met at Turin, and on March I6th, Victor Emanuel gave his assent to the law which proclaimed him King of Italy. Conservative writers all over Europe bitterly reproached the Sardinian Government with the 
revolutionary methods they had used on more than one occasion. For the first time, in fact, it had between 1859 and I86I become clear to Europe that there was a resolute will in Italy which knew when to coax and when to threaten, when to hide and when to appear, when to rush forward and when to stop, and which, when the supreme necessity arose, could dominate the weakness, the irresolution, the dissensions, and the veiled selfishness of the Great Powers, now no longer banded together by a single idea and a unanimous agreement. But was it for us to respect this weakness, for us, being human, and not wishing to take what belonged to any one else but to recover what was our own, to conquer the rights which Austria and the old governments had denied to us, to live and work in a free and peaceful emulation of the other European nations and to prevent Central Italy from relapsing into the savagery of a Christian Morocco, and Southern Italy from appearing to the traveller not as one extremity of Europe but as the beginning of Asia? The reason why we had to use these dangerous expedients was simply the spite of Austria, which, after fifty years of domination in the peninsula, had left behind her an immense heap of putrifying ruins on which we had to build a wholly new edifice. Who were 


\section{The Germanic Triumph}

the sufferers by the haste in which unity was achieved but ourselves, whose task it was for another fifty years to be constantly repairing and strengthening this new structure founded on the wreckage of the old governments? The new Italy may have made some mistakes; we do not believe that either Europe or America has to regret the fact that for half a century she has been one of the great European Powers.

Unhappily however-and herein lies the great tragedy of the recent history of Europe-there were others who were only too ready to follow her example with quite different aims. The Italian crisis as usual was followed by a Balkan crisis and a Polish crisis. The Balkan crisis was neither violent nor bloody. The Assemblies of Wallachia and Moldavia had both elected Alexander Couza as their Prince, and the two Principalities thus joined in a personal union had assumed the collective name of Roumania. The Polish crisis on the other hand was tremendous. At the beginning of 1863 Russian Poland, wearied of prolonged Muscovite oppression, deceived in the hopes it had formed of the new régime, and provoked by some of the usual insane violences of the St. Petersburg government, rose in rebellion. Small in its beginnings the insurrection spread, 
took courage, and flared up into a civil war in which no quarter was given or taken and which stirred Europe to its foundations. The commotion was so serious that the greater and the lesser Powers took a step almost without example and on April I7th presented remonstrances to the Russian Government. They were rebuffed but they returned to the charge in June, and went so far as to set out the reforms which they considered should be carried out in Poland. They were not discouraged by the further rebuff which they then received, and in August presented new remonstrances which met with no greater success. In November, Napoleon III. went so far as to propose the convocation of a congress of the Powers to discuss not only the fate of Poland, but the whole question of the Treaties of 1815 . But England, suspicious of any attack on the settlement of I8I5, opposed the proposal and failed. However, together with the other protest and remonstrances which had been made, it showed how widespread among the greater European nations was the feeling that justice should be done to the nations which were oppressed and deprived of liberty-a feeling which explains some of the views and actions of Napoleon III., many of his aspirations, and several of his failures. 


\section{The Germanic Triumph}

From all the attempts made to induce Russia to treat Poland fairly Prussia alone among the Powers had held aloof. There some remarkable innovations had been recently introduced. On January 2, I86I, Frederick William IV. had died without issue and had been succeeded by his brother William I. who had already been Regent for some time. He was an old man of sixty-four who as a boy of sixteen had taken part in the campaign of $18 \mathrm{I} 3$ against Napoleon. He belonged therefore to the generation which believed in Divine Right and the doctrine of Legitimacy; he was a survivor of the age which passed away for ever in 1848 , and of him one of his most famous ministers afterwards said with regret: "He had too many legitimist prejudices." When he ascended the throne, he at once declared that he regarded himself as King by Divirie Right and almost at once came in conflict with his Parliament about certain military reforms which were commenced on his initiative in the last years of his brother's reign. The Prussian Army had done badly in 1848 and 1849 , in the war of Holstein and in the revolt in the Grand Duchy of Baden, and had made an even worse appearance in the mobilizations of 1850 and 1859 . Many soldiers had in vain been recalled to the colours and those 
who responded to the call had shown great indiscipline and had even committed acts of disobedience in the face of the enemy. The army had shown itself ill-trained, and wanting in fighting spirit. It was at that time rightly considered, both in Prussia and elsewhere, to be unsatisfactory and out of date because it had kept to the military constitution of $\mathbf{1 8} \mathbf{I} 4$ and had persisted in the almost impossible endeavour to squeeze a first-line army of more than 350,000 men at a very moderate expense out of a poor population of ten millions. Prussia had been the first European nation which had dared to impose military service as a duty on all its citizens without exception, at the same time reducing the period of service to three years. By reducing the time and enlarging the incidence of the obligation she was able to keep under arms three yearly contingents of 40,000 men each or $\mathrm{I} 20,000$ in all. In addition, the active army had as a reserve two yearly contingents which had served their time, or 60,000 men, and about I70,000 from the first ban of the Landwehr, consisting of men between twenty-five and thirty-two. The permanent army was the military school of the Landwehr of which about half of the front-line troops was composed. As most of them had become soft by many years' disuse of arms, they 


\section{The Germanic Triumph}

were collected in regiments each of which was linked with a regular regiment in a brigade, the brigade always consisting of one regiment of the line and one Landwehr regiment. These arrangements had been in force in Prussia since I8I4 and had not been altered up to 1859 . Even the annual contingent had remained at 40,000 men, though the population had practically doubled and could easily have furnished from 60,000 to 70,000 fit men for the army. It had been the desire of the league of the dynasties to which Frederick William IV. had been so faithful all his life that neither armies nor expenses should be increased.

But in 1859 the league of the dynasties was broken, and since I 848 the Temple of Janus, which had been reopened during the Revolution, had not been closed again except for very brief intervals. Though imbued with "legitimist prejudices" the aged William was convinced that the times required a military reform and he resolved to increase his army expenditure, not in order to increase the numbers of his soldiers but to improve their quality. The military reforms which were proposed in Prussia about 1860 were the last homage paid by the German nation to the military principles which the ancient world and Europe had always professed-that the strength of an 
army does not reside in the numbers but in the quality of its soldiers. The annual contingent was now to be 63,000 men, so that the standing army would be increased from 130,000 , including officers and labourers, to 260,000 . The reserve was to be composed of the time-expired contingents not of the last two, but of the last four, yearsabout 160,000 men-and the standing army and the reserve, not including the Landwehr, would give a new first-line army of about 370,000 men, no more numerous but much more vigorous than the old; because more than half of the troops were men of the standing army, and the rest timeexpired, but quite young, men of twenty-three to twenty-seven years old.

The numbers were equal, the quality was better, and, as a necessary consequence of improved quality, the expense was to be greater. But could it be expected that a Parliament would be willing to pay millions in hard cash for such an invisible and purely conjectural benefit as an improvement in quality? This was the cause of the quarrel. The King, who did not wish to give way to Parliament and did not know how to quell the opposition, decided at last (on September 24, 1862) to appoint as President of his Council of Ministers Otto von Bismarck-Schoenhausen, whose triumphant career 


\section{The Germanic Triumph}

was destined to be the object of the most abject idolatry of Europe and of the world until the outbreak of the European war in 1914.

Whether his genius really deserved the universal admiration which it received until I9I4 need not be discussed because, in order to discuss it, it would be necessary to define what kind of genius is worthy of universal respect. As this is a point on which the ideas of mankind are neither clear nor agreed, one observation on him and his unfortunate adversary Napoleon III. must suffice here. Whatever may have been his genius, there can be no doubt - the following pages will prove it-that Bismarck. succeeded in conquering and dominating Germany and Europe during so many years because he ruthlessly and recklessly exploited for the benefit of his country, his party, his class, and his own ambition the discord and the incoherent and inconclusive agitation into which the Continent had fallen after 1848 and the end of the Holy Alliance. Nature had given him all the qualities, and fortune all the means, which could enable him to rise on the ruin of others. Napoleon III., on the other hand, succumbed because he wished, not to exploit, but to cure the ills of Europe by making its equilibrium more stable, and because he had neither the natural qualities nor 
the material means which were necessary in order to carry out so great a plan. This being said it is for each man to judge the two antagonists as he pleases; here it is not our business to judge but to narrate.

Having been made Minister, Bismarck pressed forward the military reforms and informed Parliament that they would be carried out whether Parliament approved them or not. Then, when the Polish revolution broke out, he proposed to Russia a convention whereby the Prussian and Russian armies should concert measures on the frontier for the repression of the revolt and, if necessary, even cross the frontier in pursuit of the rebels. While all Europe-including Austria, which did not wish to quarrel with the Galicians-was inviting Russia to recognize the rights of Poland, Prussia declared her solidarity with Russia in the work of repression. By this first bargain at the expense of European discord Prussia gratuitously acquired the friendship of Russia, offended by the intervention of the other Powers. A coolness arose between the Russian Court and Government and all other countries, including France with whom they were on the very point of concluding an alliance, and Russia and Prussia struck up a friendship which was to last throughout the life 


\section{The Germanic Triumph}

of Alexander II. and to protect Prussia's rear in the three wars on which she was about to embark in order to realize her ambitions. The first of these wars had neither reason nor pretext, beyond Prussia's covetous desire to deprive a weaker State of a splendid harbour and to acquire territory in which a canal could be dug connecting the Baltic with the North Sea. As recounted above, war had broken out between Denmark and Germany as early as 1848 on the subject of the Duchy of Holstein, which was populated by Germans and which, like the little Duchy of Lauenberg, belonged to the Danish crown while forming part of the Germanic Confederation. The Confederation had ultimately been obliged, owing to the protests of the Powers, to restore the Duchy to Denmark, but Germany had been offended and had made a grievance of this as if she had been deprived of something that was her own. She had her eye not only on Holstein but also on the Duchy of Schleswig, situated to the north of Holstein and indubitably Danish by language, by race, history, and traditions, finding in every act of the Danish Government a pretext for protests, accusations, and recriminations. Germany was then impotent, but Denmark was so small that she provided a safe object on which to vent the turbid 
humours and the maniacal unrest which had tormented the German race since I8I5. It so happened that certain measures taken by the Danish Government in 1863 for definitely settling the affairs of the three duchies irritated Germany to such a point that the Diet of Frankfort threatened Federal intervention. The death of King Frederick VII. which took place on November I5th and the accession to the throne of Duke Christian of Glücksburg, who had been adopted by the late King in default of male issue, and had been recognized by the Powers as Heir by the Treaty of London of May 8, I852, added fuel to the flames. The situation soon developed so far that Bismarck, who had for some time been waiting for his opportunity, made up his mind to seize the chance of sacrificing the first victim to be devoured by the hungry jaws of Germany. He therefore anticipated the Diet of Frankfort, which on December 7 th, in order to satisfy public opinion, had decided to launch a Federal execution against King Christian, came to an understanding with Austria which was at first reluctant, and in accord with the Hapsburg Emperor issued his first great defiance to Europe by requiring Denmark to abrogate the law of November I3th which had arranged the affairs of the Duchy of Schleswig. 
This was open and audacious tyranny, for the law in question was an internal law made for the territories and the purposes of the State of Denmark in the legitimate exercise of its own sovereignty. It was an act of oppression which could not be justified in any way by any interest of Prussia, for what Denmark had done and was doing within her own boundaries neither threatened nor offended Prussia in the remotest degree. Such tyranny should have been repressed by Europe. But Europe did nothing, though the insolence of the provocation was resented here and there. Russia was too grateful to Prussia for having repudiated European intervention in Poland. England, always tormented by her distrust of France, regarded Prussia as an old ally who might yet be of service to her. Even Napoleon III. was rather well disposed towards Prussia, more especially since the coolness had arisen between him and Russia and since the failure of his proposed conference on Polish affairs, which had irritated him and indeed frightened him a little. Moreover the Duchies were so small and so far off! In the result no one moved, and the two wolves were left free to devour the lamb. When, however, the Austrian and Prussian armies, after invading Holstein, passed into Schleswig and thence 
into Jutland itself, Europe was again moved. This was too flagrant an abuse of power! England intervened, and what she said and did was enough to secure the convocation of a Congress of the Powers which met in London in the month of April to discuss terms of peace. But the Congress met only to hear Austria and Prussia declare that in addition to Holstein they proposed to deprive Denmark of Schleswig. Protests and discussions were vain; no Power was prepared to come to an understanding with the others to threaten in earnest, and, if necessary, to take arms. The Congress was dissolved without coming to any conclusion and a little later King Christian, despairing of help from Europe, asked his enemies for peace and was deprived of Lauenburg, Holstein, and the Danish territory of Schleswig.

Bismarck had made his first test of the conscience and clear-sightedness of Europe. It was a small and a short test but it encouraged him to repeat the experiment with greater boldness and with a greater prize in view. He now began to prepare for war with Austria herself and for a new Germanic Confederation, with Prussia as its sole Head. It is very often said that Bismarck was the great architect of German unity, but this only serves to demonstrate that the fate of a phrase 


\section{The Germanic Triumph}

is often as strange as that of any human being. The Germanic Confederation created by the Congress of Vienna was certainly far from powerful in comparison with the great European States. Though it included the Austrian Empire and the Kingdom of Prussia so far as their territories were inhabited by Germans, it did not possess the authority which was necessary to enable it to be the supreme organ of the interests, the needs, and the aspirations common to all German States, treating all as equals and making none the tool of another. Why then did this uniter of Germany contrive a great war whereby the unity that existed was split into three fragments, which left the German States of the Austrian Empire to live apart under the Hapsburg sceptre, and constituted a Confederation north of the Rhine under the hegemony of Prussia, leaving in at least apparent autonomy the States of Southern Germany?

The truth is very different. What Germany had longed for so fanatically, and had dreamed of for so many years in a delirium constantly fomented by her philosophers, her historians, her musicians, and her poets, was not the unification of Germany in the proper sense of the term, but a powerful German Empire which would show that Germany 
was capable of doing what France had done from the days of Louis XIV. to those of Napoleon I., and even more. The Germanic Confederation could not arm itself seriously or make itself feared, owing partly to its very origin and composition, partly to the rivalry of Prussia and Austria. Germany would never be able to reforge her sword, which had once been so much dreaded, until she was federated either under Prussia or under Austria. Bismarck naturally preferred Prussia. But to exclude the Austrian Empire from the new Teutonic Confederation was so serious an enterprise that Bismarck, who was no dreamer, never thought of including therein the German States belonging to the Hapsburg Crown or of eliminating Austria. He therefore decided to split the Confederation in order to shape from its largest fragment the powerful war weapon of which Germany dreamed. The population of Prussia, however, was 18,000,000, while Austria, even after the loss of Lombardy, had more than double that number of subjects. Moreover it was probable that in the war Austria would be assisted by the most powerful States of the Confederation. Bismarck could not think of making war without an ally, and without the acquiescence of the Great Powers of Europe. He was safe from Russia, but 


\section{The Germanic Triumph}

what of France? Would France permit a great German Army to be prepared on her frontiers under the leadership of Prussia?

Everything depended on this. From the outset of his administration Bismarck, in order to ingratiate himself with France, had not spared good words, effusive cordiality, coaxing smiles, or vague promises. Every now and then, by what he said and by what he did not say, he had tried to let it be understood that Prussia would even be not unwilling to make concessions to France on the left bank of the Rhine! But, though the fox at the foot of the tree spoke very eloquently, the crow was not deluded. All his manœuvres would have been of little use if France had not in a sense been compelled to lend an ear (though with the intention of deceiving the tempter in the end), owing to the affairs of Italy and the difficulties they were causing because they had been only half settled.

The key to the events of $\mathrm{r} 866$, which are so strange when regarded by themselves, is, in fact, in Italy. As we have seen, the Kingdom of Italy had been constituted in $\mathrm{I} 86 \mathrm{r}$, and in the lifetime of Cavour had proclaimed that its capital was Rome. It had been recognized, although with the greatest reluctance, by all the Powers except 
Austria. It was however a mutilated State because it still lacked Rome and Venice. The proclamation of Rome as its capital had been the supreme pledge and the supreme defiance of the Revolution, which regarded the Pope as its most dangerous enemy next to Austria. For France it had been a source of grave anxiety. Napoleon III., who had already lost the goodwill of the Catholic party because he had allowed the States of the Church to be dismembered in 1860 and I86I, could not allow Italy to take possession of the Eternal City without running the risk of most serious internal difficulties. However, in the years that followed, the Roman Question seemed to have been practically settled, for Italy had given her pledge to France to respect the Pontifical territories and to transfer the capital to another city. In return France undertook to withdraw her garrison from Rome within two years. The Venetian Question on the other hand was an open wound which threatened to suppurate and to require operative surgery at any moment. It was not to be supposed that Venice could resign herself to the Austrian yoke when she saw by her side the free and united Kingdom of Italy, and when Lombardy, her sister in captivity, had been liberated, or that the Kingdom of Italy, 


\section{The Germanic Triumph}

having freed Lombardy, could forget the less fortunate sister and allow her to languish in the bondage of the Hapsburgs. Sooner or later the Austrian Empire and the Kingdom of Italy would come to blows about Venice.

This placed France in a great difficulty, for, if these two States alone were to go to war, it might happen that France would be compelled either to allow all that she had achieved in Italy to be undone and spoiled, or else to intervene again in Italian affairs, which was a very serious enterprise, as the events of 1859 and 1860 had proved. Napoleon III. had done his best, therefore, to favour the attempts made on more than one occasion by the Kingdom of Italy to ransom the fair slave of the Austrian Empire with money, as was the custom in barbarous times. These attempts failed because Francis Joseph would not listen to a financial proposal. Arms alone could decide who should have the right to possess Venetia! There was a danger, therefore, that Italian affairs, which remained in a state of suspense, might suddenly lead to a war for Venice, and this danger was so great that it provides an almost complete explanation of the policy of Napoleon III. in I866. If, in 1859 , he had carried out his intention of freeing Italy from the Alps to the Adriatic, if 
Austria had not persisted in keeping Venetia after having surrendered Lombardy, if Francis Joseph's narrow and obstinate mind could have realized that Austria could not stand with one foot in Italy but must either be mistress there or leave the country altogether, both Austria and France would have been able to free themselves much more easily from the net which was being so cunningly spun for them by astute Prussian ambition, and would have been able to oppose a much more vigorous defence to Prussian attacks.

Fate willed it otherwise. In 1865, when Bismarck visited Napoleon at Biarritz in order to discover what France would do if war broke out between Prussia and Austria owing to the dispute which had begun in the spring over the spoils of Denmark, he could only gather from the vague and circumspect conversation of the Emperor that France would support Prussia if Prussia were an ally of Italy or-to put it still more clearly-if Prussia would help France to settle finally the Italian Question, which, in its half-solved state, was a thorn in her side and a menace to the peace of Europe. Bismarck who, at the end of July, had made proposals of alliance to Italy, was delighted, and, when he returned from Biarritz to Paris, he exclaimed in conversation with the Ambassador 


\section{The Germanic Triumph}

Nigra, "If Italy did not exist it would be necessary to invent her!" Even, however, with the consent of the Emperor it was no easy matter for Prussia to form an alliance with Italy. The two governments thoroughly distrusted each other. Prussia feared that the object of Italy in making the bargain was merely to frighten Austria into selling Venetia. Italy on her side suspected that Prussia by her proposals of alliance and her vague threats of war was seeking to extort from Austria the lion's share of the Danish booty. Bismarck's proposals of July, I865, therefore, came to nothing, for in August had been signed between Austria and Prussia the Convention of Gastein by which the quarrels of the two robbers over their prey appeared to have been settled. It is true that this convention was the work, not of Bismarck who had proposed the alliance, but the King of Prussia, who, owing to his legitimist prejudices, was reluctant to break with Austria. But Lamarmora, then the head of the Italian Government, was not the man to draw subtle distinctions between the Minister and his Master; he became disgusted by the frivolity which one day proposed alliance against Austria and the next day came to an agreement with her, and returned to the idea of getting Venetia from Austria by negotiation. 
This break in the negotiations so much estranged the two governments that, although Napoleon had declared in October that he was in favour of the alliance, nothing more was said about it until March, I866, when Italy had definitely ascertained that it was impossible to come to terms with Austria and when new quarrels had arisen between Austria and Prussia over the application of the Convention of Gastein. These quarrels were so serious that on February 28th a conference of the highest dignitaries of the Kingdom of Prussia had definitely decided to go to war if Italy would join the alliance. On this Bismarck again officially invited Italy to treat and tried to ascertain the nebulous intentions of Napoleon III., declaring with sufficient sincerity what Prussia proposed to do. Italy did not wish to engage in these negotiations without first coming to an agreement with France. Thus Napoleon became for a moment the arbiter, as it were, of a proposed alliance between Prussia and Italy.

What use did he make of this great power which the turn of events and the discordant ambitions of the Powers had placed in his hands? He encouraged Italy to treat with Prussia; he declared to Prussia that France would require compensations in exchange for her benevolent neutrality; but at 


\section{The Germanic Triumph}

the same time-and here the history of what happens begins to be wrapped in mystery-he also entered into negotiations with Austria. Was it Austria or was it France who took the initiative? The point is obscure and deserves to be elucidated by a close study of the archives. If we may judge from the character of Napoleon III. and from the consistent probity with which French diplomacy has dealt with great affairs in Europe since the fall of Napoleon I. we may conjecture that it was Austria. Seeing the storm approaching Austria must have wished to ingratiate herself with France, as Prussia, with more enterprise, had been doing for several years, and to try in this way to insure against Italy's taking part in the war. Why did Napoleon III. refuse to listen to Austria? He had no engagements with Prussia. He had only two anxieties, one that the Italian Question should be finally settled, the other that, if one or other of the greater Germanic Powers should be increased, France should receive adequate compensation. Prudence may therefore have suggested that it would be wise to sound both sides before pledging himself to either. It is therefore quite possible that when Napoleon III. engaged in conversations with Austria while advising Italy to treat with Prussia, it was not with any Machiavellian design 
of deceiving any of the Powers with whom he was negotiating but merely because he had no clear and distinct plan of his own.

But from this moment European policy seemed to go mad. On April 8th there was signed at Berlin a Convention whereby Italy undertook to fight by the side of Prussia if war broke out within three months. On the 9th, Prussia proposed to the Diet of Frankfort that an Assembly should be appointed by universal suffrage to reform the Federal Constitution. War, therefore, was now certain. Towards the end of April, Austria took military measures on the Italian frontier; the Italian Government became anxious, replied by making suitable preparations, and referred to Napoleon III. who had advised them to conclude the alliance with Prussia and to Prussia with whom they had concluded it. By the former the Italian Government was reproved for having acted timorously and hastily, and the latter replied that the Treaty of April 8th obliged Italy to take arms if war broke out within three months between Austria and Prussia, but did not oblige Prussia to fight if Austria attacked Italy! For some days the Italian Government feared that they had fallen into a deadly trap and that they would be abandoned to the tender mercies of Austria with- 


\section{The Germanic Triumph}

out assistance. But 10 ! on May 5 th, Austria graciously offered Venetia to Italy as the price of her neutrality, and Napoleon, who had encouraged Italy to ally herself with Prussia, now advised her to seek an opportunity for getting out of her bargain. Italy, however, did not accept, for she did not wish to perjure herself. Fidelity such as this deserved some gratitude. She received nothing of the kind. On May 7 th the Prussian Government sent the Austrian Government a mild note on the subject of the disputed Duchies and commenced secret negotiations for an understanding with Austria on the basis of dividing Germany into two zones, each reserved for one or other of the two greater Powers. Austria was to be free to do what she liked in Italy. Prussia would deal with France. Austria refused the proffered treason, but on June I2th signed a secret Treaty with France by which she bound herself, even if victorious in the war with Prussia, in exchange for the promised neutrality of Napoleon III., to cede Venetia to France for re-transfer to the Kingdom of Italy, and not to disturb the balance of Germany without the consent of France. On the very same day Napoleon said to Nigra that if war broke out it might be well for Italy not to wage it too vigorously, and the Italian Govern- 
ment were given to understand through the medium of the French Government that the Prussian Queen Mother had written to Francis Joseph that she had King William's word of honour that he had concluded no treaty with Italy. Ministers on both sides had merely signed a convention which would not prevent Prussia from coming to an agreement with Austria. For a moment, all Italy believed that Bismarck had mystified Europe, as no one wished to believe that the King of Prussia had lied. Meanwhile Bismarck incited Italy to fire the train and bring about a casus belli.

Had everybody gone mad? No, but no Government really knew what it wanted. In Prussia, one party wanted war, another, more numerous and powerful, did not want it. In Austria one party wished to give way in Italy and come to an agreement with France in order to rebuild Austrian fortunes in Germany, while another wished to be supreme both in Germany and in Italy. Italy, with good reason, had little faith in Prussia; Prussia looked on Italy with suspicion. In the midst of this confusion Napoleon III., with his fixed idea of drawing the teeth of the Italian Question, had at first, since Austria persisted in keeping Venetia, encouraged Italy to make alli- 


\section{The Germanic Triumph}

ance with Prussia and had given the latter to understand that she must pay adequate compensation for her aggrandizement. When Austria had become aware of her danger and, whether in good or bad faith, had shown conciliatory dispositions, he had negotiated with Austria. We know very little about these negotiations, but it is certain that, as soon as Austria pledged herself to evacuate Italy whatever might be the result of the war, Napoleon III. first tried to withdraw the Kingdom of Italy from the alliance which he had encouraged and then to bring it about that Italy's intervention in the war should be as harmless as possible to Austria, while, as regards compensation, he continued to manœuvre between the two leading Germanic Powers, not knowing which would be the stronger. This was a very wise plan if behind it there was the resolute intention of flying to the rescue of the weaker; it was a very foolish one if it merely concealed the hope of snatching some advantage from the wars of other States without risking anything himself.

In the midst of these great perplexities, uncertainties, deceits, and duplicities, Europe was dumbfounded to see the army of Prussia, which had slumbered for half a century, encamp itself in Saxony and Silesia within a week, force an entrance 
into Bohemia under the eyes of an Austrian Army of 200,000 men, drive back one after another all the army corps which sought to bar its way, and on July $3 \mathrm{~d}$ at Sadowa inflict a disastrous defeat on the old Austrian Army, putting 20,000 men hors de combat and capturing as many prisoners. How an army which, six years before, was regarded as an outworn weapon rusted with idleness had been able at the first onset to inflict such discomfiture on the old Austrian Army which since I 848 had had plenty of opportunity of bringing itself up to date, is one of the riddles with which history delights to confound human reason when it seeks to investigate the causes of human destinies. In any case, the Austrian Army had lost a battle but not the war. The course to be followed in the resulting difficulty seemed clear to those in the French Emperor's councils at Paris. Austria must immediately satisfy Italy, and France must mobilize her army on the Rhine and impose her mediation with forces capable of subduing Prussia if Prussia dared to resist. Austria still had men and arms in abundance; all of the Prussian forces were collected in Bohemia. If the French army were to be deployed on the frontier Prussia would be compelled to accept a just peace. For the moment Austria seemed to have learned 


\section{The Germanic Triumph}

the lesson of defeat, for, at a Council held at Schoenbrunn on the morning of the 4 th, it was decided to offer Venetia to Napoleon III. and to ask for his mediation, which in fact was offered the same evening to the King of Italy and the King of Prussia.

France and Austria gave in too easily to the bewilderment caused by this remarkable, resounding, but wholly unexpected victory of the Prussian arms. It is probable that Prussia would have had the same destiny even if she had been conquered at Sadowa. None of the governments concerned had the strength to impose on their peoples the sacrifices of a long war, because they were founded on a too narrowly oligarchical basis. Francis Joseph had re-established absolutism, which meant government by a very small aulic clique, either German or Germanized, whose will it was to dominate a congeries of diverse and often hostile nationalities, the educated middle class and the mass of the people. This little oligarchy could impose itself by force and prestige on the subject races and on the majority, but it could not extort from either a protracted effort or great sacrifices. The personal government of Napoleon III. also had begun to weaken, owing to the weariness and ill-health of the Emperor, the difficulties in which 
the Empire had become entangled, and growing opposition from within.

Thus the destinies of Europe were settled for two generations between sunrise and sunset on one day of battle. On August 5th, the French Emperor presided over a great council held to decide whether his mediation should be armed or pacific. There was a long discussion between the party of prudence and the party of boldness. At first Napoleon seemed to incline towards audacity, but not for long, for he soon fell into his usual hesitation, procrastination, and self-delusion, and so let the favourable moment escape. New complications arose in Italy where the war against Austria had hitherto been far from successful. The Italian army had undergone, not a true defeat but a reparable reverse, at Custozza on June 24th, and the Government was taking the necessary steps to repair it when, on July 4th, the news arrived that Austria had ceded Venetia to France and that Napoleon III. had offered mediation. Both Government and people in consternation were agreed that the war should go on, notwithstanding the cession and the mediation, for they well knew that the Austrian offer did not include the Trentino. But Bismarck knew how to make an instrument even of this generous exasperation, 
wherewith to deceive both his ally and his enemy. He kept France in check by promising to accept mediation and to conclude an armistice immediately, making at the same time glowing promises of compensation. He incited Italy to continue the war with all her strength, swearing that it was the intention of the Prussian Government to fight to the last drop of blood. He then turned to Austria and tried to frighten her with the threat of a war $d$ outrance from Italy and to reassure her by offering moderate peace terms. Austria would cede to Italy Venetia only, and no territory to Prussia. She would have to agree to the dissolution of the Germanic Confederation and recognize the new Northern Confederation in which Austria would not be included. Prussia would receive Schleswig and Holstein and be permitted to absorb in North Germany the territories of Hanover, the Electorate of Hesse, the Duchy of Nassau, and Frankfort.

So long as Austria had hopes of assistance from France she was deaf to these blandishments, but, when she knew for certain that Napoleon III. did not mean to threaten seriously because he was afraid of war, she began to lend an ear. France on her side grew weaker and more hesitating the more Austria inclined to peace, and the two 
governments which united would have been an invincible force, drifted apart in isolated weakness and were subdued by the ambitions and implacable energy which had planned the war. By flattering and threatening each in turn Bismarck succeeded between July roth and July 22d in getting Napoleon and Francis Joseph to consent to the peace he wanted; on July $22 \mathrm{~d}$ he arranged a five days' truce with Austria, and on the 26th the Armistice of Nikolsburg was signed. Italy, his ally, was not consulted or even informed! On the contrary, on July 22d, the very day on which the first truce was signed, the Prussian General Staff was urging Italy to continue the war vigorously! When the Armistice of Nikolsburg was concluded Napoleon III. woke up; he understood that he had been guilty of weakness and irresolution, he wished to regain the time and the advantage he had lost, and he claimed the compensation at which he had so often hinted. It was too late! France could no longer count on Austria and Prussia knew that Napoleon would not make war alone when he had not ventured to threaten it when Austria was in arms and ready to help him. Compensation was refused.

So it fell out that once again the Italian Question was not fully solved, because Prussia had made 
peace without consulting Italy, and she had to be content with what Prussia and Austria were pleased to give her. She was denied the Trentino -a land which is purely Italian and the key to the defences of the Valley of the Po-and Austria kept enough of Friuli to serve as a bastion from which she could swoop down on the defenceless plain. Thus the German race could boast once more of brandishing a threatening sword in the eyes of the world. Prussia as increased by the territories she had annexed now counted about twenty-four millions of inhabitants, and had united under her sceptre in one confederation twenty-one other States whose population amounted to six millions. She therefore had at her disposal a standing army of more than 300,000 men and could mobilize for war more than 900,000. Further, by secret treaties concluded in 1866 , the States of South Germany, the Kingdoms of Württemberg and Bavaria, the Grand Duchies of Baden and Hesse, had pledged themselves to place their forces at the disposal of the King of Prussia in case of war. Bismarck was now master of Prussia and therefore of Germany. In the presence of Prussia's victory and the hopes it raised for the future, all opposition from the legitimist prejudices of the King to the opposition of the democratic parties, 


\section{I64 Problems of Peace}

from the spirit of particularism to the jealousy of the minor States - all vanished. In the nation, inebriated by its first victory, there was a rapid growth of cupidity, ambition, and audacity, and four years were enough for Bismarck's preparations to attack France in order to create a German Empire on the ruins of the Empire of France and to conquer the hegemony of Europe. 


\section{CHAPTER VI}

THE GERMAN PEACE AND THE GERMANIZATION OF EUROPE

$$
\text { (1870-19I4) }
$$

THE war of 1870 is yet another of the riddles with which history is pleased to confound the inquirer into the shaping of human destiny. It followed from the first the precedents of the war of 1866. This time also the preparations were concealed behind a veil of reassuring words. Once again the aggressor did everything possible to distract his adversary by making him believe up to the last moment that a compromise was possible, by isolating him, and by distracting, flattering, or terrifying all those who could have come to his assistance. Once again the adversary was overpowered and struck down, not as before by one, but by three or four resolute blows, in the course of six weeks, and the nations of Europe were so completely paralysed by amazement at this sudden catastrophe that they remained speechless and 
impotent in its presence. If the men who governed Europe in 1870 could not be expected to divine the future they should at least have remembered the past and profited by recent experience. How was it that they allowed themselves to be surprised a second time, and in the same way, by the same ambition, after only four years? Why did the nations at the outset of the war which was to decide their destiny look on with folded arms? Were they so much terrified by the German victories that they could not move, even when the victors proposed to cut from the body of France two masses of living flesh, Alsace and Lorraine, and to impose a monstrous indemnity?

Any one who studies the war of 1870 as a merely military fact or a series of strategical and tactical combinations carried out by the two armies, will never succeed in solving this riddle. France was attacked, exactly as the wolf attacked the lamb in the fable, on the pretext that either now, or a year hence, or in ten years, or in a century, she would certainly attack Prussia if Prussia did not spring suddenly at her throat. The Germans themselves admitted this, not without complacent smiles, as soon as victory had relieved them of the burden of the war. The intrigues which led to the candidature of a Hohenzollern for the Throne of 
Spain, the laborious diplomatic negotiations of which this candidature was the subject, the duplicity exhibited by Prussia, the dinner at which Bismarck in the presence of Marshal von Moltke and General von Roon - and to their great delight -altered the dispatch which was destined to be known in the chronicle of human wickedness as "the Ems forgery," are the commonplaces of history. How was it, then, that the world changed sides and reserved all its sympathies for the aggressor and cried to the lamb weltering in its gore that it was rightly served for having provoked the wolf, while it applauded the wolf for its gallant deed?

It is equally difficult to explain why the victim succumbed to the assault of the aggressor in less than two months though in possession of forces which should have sufficed for a very prolonged defence. The invincible excellence of the Prussian army which the world has admired for so many years is a discovery made by Europe after it had won the victory which it was antedated to explain. In 1870 the French army may have been somewhat out of date, but the Prussian army was still partly an improvisation of the previous ten years. After weighing the respective merits and defects, experts were of opinion that the two armies 
which were much the same in numbers were about equal in value. If the Prussian artillery and sanitary services were better, the French had better infantry and a better commissariat. The Prussian army was better led, but the French did not lack capable generals whom a strong government could have substituted for the less efficient ones before it was too late. The fact that the French soldiers served for five or seven years was regarded by the Germans themselves as a great advantage for their adversaries. In fact the forces of the two States were in a balance. Why then was it that, instead of having to sustain the long, bitter, and difficult struggle which most people expected, the Germans passed from one victory to another until they appeared before Paris two months after the declaration of war?

The war of 1870 is an insoluble enigma to any one-be he historian, strategist, or statesman -who does not understand that it was the tragic dénouement of the political crisis which began in Europe with the Revolution of 1848 . In that war France was beaten, not so much by the arms of her enemies as by the political weakness which had been undermining her ever since the fatal June days when she lost confidence in the new principle of authority then enthroned, without acquiring 
an unwavering confidence in the old principles of authority already so often discredited, sent into exile, and once more recalled to a kind of semiactivity, in order to gain time. From this perplexity arose the curious reign of Napoleon III., weak like all the children of perplexity and fear. In the course of seventeen years it grew weaker still, owing to the growing doubt of its own legitimacy, the renewed difficulties at home and abroad which had wearied it out, the too numerous enterprises attempted rather with noble objects than with adequate means, and finally by the exhaustion of the man who had every day to contrive a new mask of Hercules to disguise the feebleness of his government. That government was not even capable of using to good effect the weapons it possessed,-it entered the arena tired before the fight began; it had not the wit to entrust the command to men of approved capacity; it hesitated between various plans of campaign-it would and it would not-; it nursed favourable opportunities and failed to enforce obedience, and at the first reverses it lost its head and uncovered both flank and front to the enemy.

Europe, terrified but unmoved and mute, looked on at the butchery because, after 1848 , in the wars, the diplomatic conflicts, and the civil struggles 
by which she had been divided and disturbed, she had lost sight of her common needs and her common interests. Austria understood the danger and several times sounded the European Powers to see if there was no way of coming to an agreement to impose a check on the conqueror. But Russia, remembering Poland, saw everything through Prussian spectacles and would not listen to reason. She was helped in this attitude by England who, always gnawed by jealousy of France, always occupied in her exact but petty calculations, again did nothing herself and prevented others from doing anything. Italy on her side remembered Mentana. . . Thus Austria's efforts failed. Italy's idea was rather to seize the opportunity of taking possession of Rome, and Russia's to proclaim authoritatively, without asking the permission of the other Powers, that the second article of the Treaty of Paris was cancelled. Prussia, on the other hand, which at the beginning of I866 was still a little State of eighteen millions of inhabitants and the smallest of the Great Powers of Europe, could boast that in less than five years she had humiliated Austria, dismembered France, and founded in the heart of Europe under the form of a Confederation the last of the Empires which issued from the historical upheaval 
of the French Revolution. So rapid a growth, so startling a surprise had never before been seen in Europe.

Such was the will of Fate. Are we therefore to conclude that in 1870 Divine Right won by force of arms yet another victory over the spirit of Revolution? It cannot be denied that the Prussian victory did constitute a sort of half revenge for the revolutionary successes of 1848. A king who believed himself to be the Lord's anointed, and who had abandoned none of the rights which the Revolution had most tenaciously disputed with sovereigns, such as the right to summon and dismiss ministers, to make war and peace, to conclude alliances; a minister who had left nothing to Parliament but the business of paying the reckoning for his policy; a privileged aristocracy, militarist and bound to the sovereign, had succeeded in dragging the educated and the middle classes resolutely united with the masses, into a great war, and in conquering France, weakened as she was by the irreconcilable struggle between the new democratic idealogy and the ancient principles of authority. What an argument for those who, in Germany and elsewhere, opposed the parliamentary system, liberal and democratic doctrines, the principle of nationality, and the other idealist 
theories according to which force might be disarmed by depriving it of its sovereign rights over the destiny of nations!

The new German Empire was in fact very ready to pose as the champion of law and order against revolutionary Europe. Bismarck from time to time gave himself the airs of a new Metternich, and the parties usually styled Conservative did their best all over Europe to make the most of the German successes for their own purposes. The victory of Germany, however, was not followed by a period of reaction which could be even remotely compared to that produced by the Holy Alliance. The classes and the parties which professed Liberal opinions were now so strong all over Europe except in Russia, that not even the German sword could lay them low again. Nor were replies wanting to the argument provided by the German victory. In the government of Napoleon III. the spirit of the Revolution had been mixed with many elements surviving from the ancien régime, and it was to this contamination and not to the spirit of the Revolution itself that democratic logic attributed the defeat of France. There was even more to be said. Though William I. figured in Europe as the standard bearer of Divine Right, the empire which he founded had not scrupled or 
feared to include Universal Suffrage among the instruments of government, recognizing in the will of the People the principle and the fount of authority of the Imperial Parliament; and even Republics and Democracies were now to seek in Prussia models for certain institutions, such as universal and compulsory military service and education, which, after the German victories, democracy itself was inclined to recognize as its own legitimate children culpably abandoned by their mother and adopted by an astute Monarchy. After 1870 the system whereby many of the richer classes even in France had escaped Military service by paying for a substitute was abolished, and the fable that the real victor at Sadowa and Sedan had been the elementary schoolmaster reconciled to public education many governments which had previously feared it as the first step towards associating the masses with the ruling of the State. Again it could not be denied that after the war of 1866 the Emperor of Austria had been compelled to reconcile himself with Liberal opinion in Hungary by granting a Constitution with two Parliaments, one at Vienna and one at Buda Pest, that in 1870 the Empire of Napoleon III. had fallen in France, and the Temporal Power of the Popes in Italy. Germany's wars had in fact had the double 
effect of uprooting the idea of Divine Right outside the Germanic world and stimulating it within that world.

The victories of the German army did not so much create a new opposition between the principles of the Holy Alliance and the ideas of 1848 as confuse both in the mind of Europe, so that peoples and governments began to lose all clear consciousness of the premises and the conclusions of either system. To the internal confusion in all the States was now added their individual isolation and a universal fear of war. It was now clear that there no longer existed in Europe even the shadow of a public law which would protect innocent weakness, that any State could at pleasure attack its neighbour on any specious pretext, annex its territories, impose indemnities, and humiliate it, in the certainty that, if it proved to be the stronger, it would be admired and applauded by all the world. How was one to know who were friends or who foes? What power save the power of the sword could be trusted to protect a nation's treasures against the cupidity and the ambition of others? The years which followed I870 were for Europe years of mutual distrust, of continual alarms, and anxious vigilance.

In Russia the Court and the Government con- 


\section{The German Peace}

tinued to the German Empire the friendship they had lavished on Prussia, but not without regretfully recognizing that the German Empire was a more dangerous neighbour than the Germanic Confederation had been. Austria distrusted Russia and looked with rancour and suspicion on both Italy and Germany. She feared that Italy might attack her in order to secure the "unredeemed" territories as they now began to be called. Italy on her side was afraid that Austria might attack any day in order to revenge on her the defeats she had sustained at the hands of Prussia. For she could now no longer rely on French assistance, partly because the old bonds of the Kingdom of Italy with France had been broken by the fall of the Empire; partly because the Republic, though not without interest in Italian affairs, was not involved in them as the former régime had been and was fully occupied with the reconstruction of France; partly again because the neutrality observed by Italy during the war and the conquest of Rome had estranged a portion of the French nation. There were those in France who suspected Italy of an inclination to make war on her allies of 1859 as there were some in Italy who accused France of wishing to attack Italy in order to restore the Pope. France, finally, was occupied 
in giving a stable balance to the Republic but she was full of hatred towards Germany, suspicious of Italy, uncertain of Austria and Russia. She desired and at the same time feared a new war with Germany, and was preparing for it as if it might break out any day.

There was, in fact, a universal conviction and a universal fear that the German victories might be the seed and the beginning of new wars greater and more terrible than the old, and all men were doubtful of the present and fearful for the future. There was good reason. Like all the empires which emerged from the great historic upheaval of the Revolution the German Empire had no other title of legitimacy but force. It is said-to the great surprise of some people-that on the day on which William I. was proclaimed German Emperor at the Château of Versailles by the Sovereign and the Princes of Germany, he was in a very bad humour about his new title and so angry with his famous minister who had conferred it on him, that he would not speak to him. But if it be remembered that William I. had fought the first Napoleon and had served the Holy Alliance, if it be understood by what a tragic contradiction authority when it strengthens itself must divest itself of its legitimate titles, and on the other hand when it 
wishes to seem legitimate must weaken and emasculate itself in its respect for legality, it will be clear that the old monarch, alone among the festive crowd on that day of triumph, saw the writing on the walls of the ancient castle of the French Kings which portended death to his new empire.

The old man could still believe and proclaim in good faith that his people regarded the modest Crown of Prussia as a gift of God. But how could it be pretended that his new and more splendid Imperial Crown was God-given when it had in fact been fabricated and tendered to him by his companions in arms before all the world at the end of his fortunate adventure in France? This crown had been the prize of victory, and, as defeat might deprive him of it again, it was necessary to defend it against the rancour and the vengeance of the two great States which German arms had conquered, against the jealousy, the distrust, and the fear of the other Powers of Europe which had been three times surprised by the audacity of Prussia. This obligation may well have seemed a dangerous one to an old King who, like all his generation, had been brought up to distinguish more accurately than his juniors the two elements of authority which the nineteenth century sought 
to confuse, namely, legality and force. The world was right in thinking that the new Empire would have to defend by force what it had gained by force, and that its example would be the source of new wars, whenever a powerful State felt itself to be strong enough to despoil a weaker neighbour.

The course of events appeared to make sport of these alarms. Once more, as at the beginning of the century, the war gave rise to a long peace. The new peace, however, was not imposed on each State by the voluntary agreement of the others. It was the result of an inextricable mixture of fear, distrust, and suspicion. It was based on alliances which lasted long but had little sincerity, on simulated friendships, and hidden enmities. It is necessary that we should clearly understand what was the precise nature of the "German Peace," which for forty years was at once the vital necessity and the mortal torment of Europe, if we are to grasp the meaning of the present crisis in Western civilization.

When they had won their third war William I. and Bismarck, terrified by their own good fortune, and fearing the vengeance of the vanquished, thought of nothing but obtaining a peace which could secure the rich booty of the war, and took 
measures to impose on Europe a peace which may well be called German, not only because it was dictated by Germany, but because in the means employed it is easy to recognize the reckless extravagance of the Germanic spirit. Bismarck's first thought was to prevent a coalition of the two victims of his policy, France and Austria. He therefore reconciled himself with Austria, the one who had suffered the less cruel blow, and whose community of language and culture with Germany and a similarity of institutions made an understanding easier. At the same time, however, he did not wish to quarrel with Russia on whom he relied in case Austria and France should unite to attack Germany. Thus from 1870 till 1878 he did all he could to make friends with Austria without offending Russia who distrusted Austria, and to establish an alliance between the three Northern Empires which would have a distant resemblance to the Holy Alliance. The war which broke out between Russia and Turkey in 1878 envenomed too greatly the mutual hatred and suspicion of Russia and Austria-Hungary and compelled Bismarck to choose between them. Despite her many weaknesses Austria would have been much stronger than Russia on any European battle-field. Bismarck, therefore, in order to prevent an alliance 
between Austria and France could not hesitate to renounce Russian assistance. Moreover an alliance with Austria, to the Germans in the two empires, had the aspect of a final reconciliation of the whole Germanic world, the expiation of the fratricide committed in $\mathrm{I} 866$.

In 1879 Bismarck finally succeeded in persuading Austria, in her anxiety about Russia, to conclude the alliance which pledged Germany to help Austria in the event of a Russian attack, but did not pledge Austria to help Germany if attacked by France. The conqueror must have been in dire need of the assistance of the conquered to agree to such terms! Fearing, however, that Austria might use the alliance in order to aggrandize herself in the Balkans or in the East or to attack Russia, and that Russia might be driven by his compact with Austria to ally herself with France, Bismarck in 1884 concluded with Russia a secret agreement which is famous under the name of the Reinsurance Treaty. By this treaty Germany pledged herself to neutrality if Austria attacked Russia; Russia on the other hand promised not to intervene if France provoked a new war with Germany.

It is not surprising that Austria should have consented to a reconciliation with Germany on 
these terms. How could the House of Austria, always anxious to aggrandize itself, refuse an alliance which provided gratuitously a powerful ally in the event of a Russian attack? The Austrian Emperor must have been in mortal terror of another disastrous war when his empire was already beginning to break up as the result of the defeats of $1859-1866$ and the rudimentary liberties which had been conceded by the new constitutions extorted by the agitations of the nationalities. Force had created the Austrian Empire during the Napoleonic wars by assembling round the States, which for centuries had recognized the Hapsburgs as their legitimate sovereigns, many lands of much more recent acquisition populated by diverse races, and by obliging them all to obey the absolutist, aristocratic, and bureaucratic government at Vienna. But when, after 1859 and 1866 , the empire began to totter and seemed less invincible and inexorable than heretofore, when, by recognizing the national existence of Hungary, it showed itself no longer able to crush all internal opposition as in 1848 , the populations held in subjection to the Hapsburgs, not by respect for legitimate authority but by force, took courage.

A period of crisis set in for the empire which force had founded, but which force was now 
abandoning. This crisis explains why in I882, two years before the secret treaty between Germany and Russia, Germany and Austria had admitted Italy as a third party to their alliance. In order to understand this remarkable event we must keep in mind that Italy possessed a territory only half that of Austria, inhabited by a population which was then at least a third less numerous, that the Austrians were at her gates, for the frontier even after 1866 had been so adjusted as to give Austria all the advantages if she chose to attack, and finally that the Italian army was not only less in numbers but still raw and inexperienced, whereas Austria had been a military empire for centuries. There was, in fact, such a grave inequality of forces as to make the isolation in which Italy found herself after I870 very dangerous, and it is not strange that, as France could no longer help her, she should seek a new ally. That ally was naturally Germany, both because there was no other, because the secret aims of German policy were unknown, and because it seemed that Germany also had reason to fear the revengeful spirit of the Hapsburgs.

Thus it was that in 1877 Francesco Crispi, one of the leaders of the Left who had come into office in the previous year, visited Bismarck at Gastein 
and in the name of his Government proposed an alliance between Italy and Germany in order that the two States might unite to defend themselves if France or Austria attacked either, and prevent new encroachments by Austria in the Balkans. $\mathrm{He}$ received the reply that, though Germany was ready to help Italy against France, she would on no account whatever do anything to annoy Austria, that Germany had no interests in the East where the Russians and the Turks were fighting, and that, provided the conflagration did not spread to Europe, she did not mind if Austria got what she wanted in the East. As Bismarck was then preparing his alliance with Austria the conversations at Gastein led to nothing. How was it then that Italy, which had come forward in 1877 with an offer to ally herself with Germany against Austria and had retired on finding that Germany was too close a friend of Austria, allied herself in 1882 not only with Germany but with Austria as well?

The usual answer to this question is "Tunis!" When France established her protectorate of Tunis on which Italy also had designs, Italy hesitated no longer and went over to the enemy. Yet the offence created by Tunis was rather a final occasion of the alliance than its chief or even one of its principal causes. For in this very treaty of 
1882 Germany in no way pledged herself to prevent French expansion in the Mediterranean, but, it would appear, only to help Italy if attacked by France. Italy on the other hand engaged herself for five years to help Germany if attacked by France and Russia, and to remain neutral if Germany took the offensive against France in another "preventive war." Further, though Italian Statesmen have always distrusted France's Mediterranean ambitions which Germany was then encouraging, they have never seriously feared her aggression. Crispi himself, though not a friend of France, in his conversation with Bismarck at Gastein, disposed in a very few words of the danger of a war with France which in his opinion could only be brought about by a victory of the Conservatives at the coming elections (when as every one knows, they were beaten), and discussed the Austrian danger at great length. Why then did Italy make the alliance in $\mathbf{r} 882$ ? What was in fact the compensation guaranteed to Italy?

It was the friendship and peace which Austria promised her. Italy was compelled to become the ally of Austria and Germany in order to defend herself not against France but against Austria. The Triple Alliance was therefore in principle a tribute to the triumph of Germanism which Italy 


\section{The German Peace}

could not evade once the German Empires, rivals in 1866 , had come to terms. If, before she entered this alliance, Italy could rely but little on France in a war with Austria, all hope of such assistance was lost when Germany was in alliance with Austria. To aid Italy, France would have had to run the risk of a war with Germany. Therefore, as she could no longer count on a French alliance, and as she, for excellent reasons, did not wish to find herself at grips with Austria, what remained but to bow to necessity when Bismarck, when again approached, replied that in order to reach Berlin, it was necessary to go round by Vienna.

When a State, in order not to be overwhelmed by a more powerful enemy, takes the desperate course of forming an alliance with him, it is necessarily compelled to abandon all the advantages of the bargain. This Italy found to be only too true. Germany obtained assurance that Italy would either remain neutral or assist her in a new war with France. Austria secured a pledge that Italy would repress "Irredentism," that she would not assist any of her enemies, and would therefore leave her a free hand in the East. Italy got nothing but a promise that Austria would not harm her. The first Treaty of the Triple Alliance proved in fact that, as the balance of power in Europe had been 
disturbed, first by the war of 1870 and then by the Austro-German alliance, Italy in spite of the wars of I859 and I866 had not yet gained complete independence, for she was not in a position to discuss as an equal proposals of alliance with Austria and Germany who were already allied, but was compelled to submit to their will to an extent which was inconsistent with Italy's national autonomy. This first treaty was so sterile, not to say so burdensome, for Italy that in $\mathbf{1 8 8 7}$, when it was about to expire, some improvement was brought about. Count Robilant, a skilful minister, by a threat that he would not renew the bargain, secured the addition of two new treaties to the old agreement of 1882 . One of these, with Germany, provided that Germany would give armed aid to Italy if France, in Africa or elsewhere, attempted to alter the balance of power in the Mediterranean to Italy's disadvantage; the other was an agreement with Austria-Hungary pledging the latter to respect the status quo in the East as far as possible. If the necessity arose to occupy temporarily or permanently territories in the Balkans or on the Turkish coasts, or in islands in the Adriatic or the Agean, the occupying power was to proceed with the consent of the other party and give adequate compensation. At the same time, in February 


\section{The German Peace}

and March, 1887, Italy, England, and Austria (so far as is known by a mere exchange of notes) concluded a naval alliance the object of which was to maintain the status quo in the Mediterranean. England undertook to assist Italy and Austria with her fleet against any Power which attempted to alter the existing position in the Mediterranean or the adjacent seas.

As thus renewed the alliance was no longer for Italy an empty nutshell as it had been in $\mathbf{I} 882$. There was a kernel though it was a very small one. The minister who gained this advantage gained it partly because he knew how to manœuvre, but also because his desires coincided, if not with Austrian aims, at any rate with the profound designs of German policy. In 1887, when the Triple Alliance was renewed with these additions and the naval agreement between Italy, Austria, and England was concluded, the aged Bismarck could contemplate with satisfaction the work which he had now completed. After making three wars he had succeeded, like the Holy Alliance, in imposing on Europe a peace which had lasted seventeen years and was destined to last for another twenty-seven. Unlike the Holy Alliance he had not united governments in an understanding, which was now impossible owing to the fact 
that in the European Babel the governments spoke all manner of different languages; but he had so bound them in their rivalry for distant conquests, that, while always at variance, they never dared to come to blows. This he contrived by means of a diabolical network of treaties the threads of which he was able to keep in his own hand, because Germany alone was disinterested in the midst of all these colonial ambitions. By the Austro-Hungarian alliance and the naval entente between England, Austria, and Italy, he compelled Russia to keep the peace by threatening her with the German army, and with the British Fleet if she tried to aggrandize herself in the Balkans or in the East. But he reassured Russia, after frightening her, by the secret treaty against Austria, on condition that she did not attack Austria or seek to disturb the existing equilibrium in the Mediterranean and its adjacent seas.

By the new treaties of $\mathbf{I} 887$ between Italy, Austria, and Germany, he was able to restrain the ambitions of Austria in the Balkans and in the East, and to compel Italy, whether she would or no, to live at peace with Austria, to persecute Irredentism and to attempt nothing new in the Mediterranean. Italy was promised assistance only in the event of attempts by others to disturb the bal- 


\section{The German Peace}

ance there! Finally, by means of all these treaties and the naval entente between England, Italy, and Austria, Bismarck put in operation what had been one of the cardinal principles of his policy since 1870, the segregation of France from all the great combinations of European policy and from the concert of the Great Powers, encouraging her by way of compensation to send expeditions to Asia and Africa. Moreover, even had she not been distracted by internal crises, what could France have done alone? Her position once more recalled the isolation in which she had found herself in the midst of a distrustful and hostile Europe in 1815.

Such was the peace which triumphant Germanism bestowed on Europe after I870; an inextricable imbroglio of distrust, rancour, fear, friendships, and enmities, real or pretended. This situation was dominated by Bismarck, not only because he could every now and then sound a threatening note of military terrorism, but because he had resisted the ambition of distant expansion to which other States had yielded, and had thus been able to weave an invisible and magic net in which for twenty years he held the Great Powers of Europe fast bound and impotent to break it.

There came one at last who did break it. The generation born between 1860 and 1870 remembers 
that William I. died in $\mathrm{I} 888$, having lived to be over ninety, and that, after an interregnum rather than a reign of three months, he was succeeded by his grandson William II. a young man of twentyeight. It also remembers that, little more than a year after his accession, William II. dismissed the veteran Bismarck. It is less known that, when Bismarck had retired into private life, William II. annulled the secret treaty concluded with Russia in $\mathbf{1} 884$, abandoned the policy, the object of which was to keep Russia in check by the fear of Austria, and Austria by the fear of Russia; left Russia to provide for her future as she thought fit, did all he could to strengthen the alliance with Austria and Italy and, as opposed to Bismarck who regarded Oriental affairs as extraneous to German policy, decided that Germany should go forward in the East. How are we to explain so sudden a change from the old to the new generation?

When William II. ascended the throne the world in general frowned on him. It was everywhere rumoured that the young monarch had an ambition to add to the trophies won by his grandfather, and that he would reopen the Temple of Janus. Then the world repented of its suspicions, believed what he said and saluted him as the Emperor of Peace. Today the world suspects 
that it has been duped by a quarter of a century of consummate acting. For us, whose eyes cannot pierce the deeper recesses of his conscious or unconscious motives, it will be enough to make clear how he gradually was led to challenge the world to battle by the natural consequences and the inevitable development of the policy of Bismarck, although he had himself disavowed that policy. There is no doubt that Bismarck and William I., having in seven years successfully carried out three grand acts of spoliation of territory and treasure, were sincerely desirous of stopping short and living at peace with the victims and the spectators of their crimes. It is, however, much easier to start human affairs on a treacherous incline such as this than to check them halfway down the slope. There were only too many reasons why Germany and Europe, once launched on this precipitous career, could not obey when Bismarck cried, "Stop!"

For one thing the art of war had been falsified in all civilized Occidental States by the war of 1870. The German victories had as usual been attributed, not merely to the tactical and strategical plans of the more powerful combatant, but to a kind of prodigy the secret of which was sought in strategy, in tactics, in theory, in organization, 
and so on. But the German army was an audacious improvisation, full of defects as well as of qualities, and of these defects and qualities the military art in its technical considerations of the German victory had been well aware. It was therefore led to regard as true principles what the experience of centuries had judged to be false. Such doctrines were that the strength of armies varies directly as their numbers, and is consequently increased as the period of service is diminished; that the nation in arms is the most potent and perfect of all armies; that the political principle of military service is better than the professional, even in cases where an expert rather than a numerous army is required; that the perfection of the weapons invented and made by modern industry is in itself a power to a certain extent independent of the value of the soldier. The result was that after 1870 all the States of Europe sooner or later imitated the military institutions of Germany. They declared for a universal obligation on all their subjects to serve in the army for three years and-taking Germany as their model and master-every State began to increase the number of its effectives and to spend all its time inventing new and more powerful instruments of destruction. Such was the universal suspicion and fear that 


\section{The German Peace}

whenever one Power brought in some increase or improvement, all the other Powers felt obliged to imitate it, and this led originators and imitators alike to still further increases and improvements.

Thus, in the vicious circle of the German peace, began the unlimited rivalry in armaments which was a new phenomenon in history after 1870. It was unlimited because it recognized no limit but the amount of money and the number of fit men available. Was it, however, reasonable to suppose that a people which, now that it had won three wars, regarded itself as invincible would continue to increase its army merely in order to maintain its power as Bismarck wished, and not to increase it? To credit Germany with so much moderation and prudence was all the more rash because even the satisfaction of victory had not calmed but rather had exacerbated the mania which had excited the German people since 1815 . Persuaded of its invincibility in war and master of practically all the sciences, the German people was not content to maintain its military and scientific primacy. They wished to be as rich as France, England, or the United States, to rival these powers in all the branches of trade in which they were the leaders, to rob them of the admiration and authority and 
of the power which they enjoyed in every country in the world.

The enterprise was difficult because the rivals were strong, but the Germans were numerous and were increasing every year. They have a soil rich in iron and coal. They are tenacious, insinuating, patient, and laborious people, possessed of the capacity for observation, imitation, and solidarity. They know how to study and to filch the secrets of others, how to apply, develop, and perfect the discoveries they have stolen and how to co-operate with each other. What is more important, they are exalted by a strange species of Messianic nationalism such as has not previously been seen in the world. They regard themselves as eternally at war with other peoples for the greatness of Germany. They do everything as if they were on the field of Sadowa or Sedan. They write, teach, trade, cross the ocean in search of work, smelt iron, and blow glass all in the same spirit.

The doctrines of English Liberalism of the Manchester School, so much prized in France and Italy in the first half of the nineteenth century in opposition to the despotism and paternalism of the old governments, had been coldly received in Germany. German men of science had taken 
pleasure in defining the political economy of Adam Smith as "cosmopolitan economics" which might work in an ideal, colourless, and non-material world with an imaginary race all the same in language, passions, customs, and interests, where there were no rival races, nations, or States. To this abstract doctrine they opposed the so-called "national economics" which regarded agriculture, industry, and commerce as vital organs of each separate nation and which, far from rebelling against the State like the orthodox Political economy, gladly subordinated itself to State control.

Even before 1866, while Germany was weak, these doctrines had exercised a certain influence there, inducing the larger States, for example, to reserve to themselves the construction and working of railways instead of leaving this to private capital as had been the case in England and in France. But both in Germany and elsewhere these views had been obscured by the vogue of English Liberalism and the influence of the classic economic theory. After 1870 the new economics shared the fortunes of the Empire and, tinged with the new Messianic nationalism, they no longer spoke under their breath and in modest tones to Germany alone. They lectured to all Europe; were called into council by the government. 
To the non-intervention of the Manchester school, they opposed a programme of social legislation which professed to mitigate or altogether abolish the most cruel of the rites of the religion of fire and steel which all nations now so ardently professed. To British Free Trade, which had presented itself to the world as opening its arms to all peoples, they opposed protection as a vivifying and warlike doctrine. In 1879 the Empire enclosed itself within a Chinese Wall of Tariffs and Customs Duties.

And now the world saw this people once more overturn the experience of ages and the natural order of cause and effect. It saw them, after winning its wars by shortening its term of service and feariessly applying the principle of the nation in arms, successfully create within the fortress of a protective tariff a lively expansive industry continually developing, always prepared to meet its competitors, always fertile in new subtleties, new cunning, new inventions, and new initiative. In Germany the protected industries did not grow prematurely old as they did elsewhere. They used the tremendous benefits of protection to increase themselves, to perfect their machinery, to add to the number of their workmen, to produce more, to try their fortune in more distant, more 


\section{The German Peace}

difficult, and less known markets at the cost of great sacrifices, and even laid out in this foreign trade part of the profit they made at home, often accepting a less reward for their trouble and greatly increased responsibility than they might otherwise have done, so thoroughly were they impregnated by the spirit of nationalism and the determination to vanquish other nations in industry and commerce as they had done in arms.

In fact, although since 1870, Germans have continued to emigrate to all latitudes as they had done before, to present themselves wherever there was need for a laborious workman or a zealous and servile employee to write countless volumes, to teach everything knowable, to trade and invent, and to adore fire and steel as the new gods of riches and power, they are yet no longer the same peoples. Their triumph after the long period of hope deferred has changed them. In their own country and abroad, traders or teachers, captains of industry or scholars, administrators or bankers, statesmen or ecclesiastics, the Germans' one desire is to prove to others or to themselves that Germany is the equal or more than the equal of all other nations. The child of war, Germany seems unable to exist except by fighting, by continuing in industry, art, and science the combat interrupted on the 
battle-field. How could such a people recognize itself in the cautious prudence of the old emperor and his ministers?

William II. accordingly sent the old Chancellor into retirement in order to be able to adapt to the needs of the time and to carry on the policy which had now disillusioned and terrified its author. He ceased to balance between Russia and Austria, but resolutely took Austria's part, and decided to use the alliance no longer to maintain equilibrium but to dominate Europe, not openly, as Napoleon I. had done, or secretly like Nicholas I., but in such a way that the world could know it, yet not so manifestly that they would be afraid. $\mathrm{He}$ planned to make Germany the controlling power in the East by entering into a sort of alliance with the Mussulman world. He recognized the new German industry alongside of the Army, Agriculture, and the schools, as a legitimate daughter of the Empire. He protected it and helped it to spread itself all over the world, mitigating by commercial treaties the too drastic operation of the protective system, and putting at its service all the powers of the State. He designed a great Navy at the same time that he was continuously increasing the Army. Finally he did not forget to declare himself the protector of Peace, while 
every now and then rattling the sabre, or to lavish fair words, cordial assurances, and protestations of friendship on all the Powers including England, Russia, and even France!

The political methods of William II. were considered to be noisy, impulsive, contradictory, illbalanced, and savouring of charlatanry. These defects were too conspicuous to escape notice in the world and even in Germany. But the close observer will not fail to perceive under the want of skill the continuation and amplification of the Bismarckian policy which was desired by the German People and the determination to use the power of the Empire no longer to preserve what it had gained, but to increase its possessions. There is no doubt that the limits which Bismarck wished to set to Germany were prudent, but he alone saw this in the midst of the tumult of ambition and cupidity, to which he and the course of events had given rise, and the impulse which he, and what he brought about, gave to these passions, was too strong to be contained by the boundaries which he designed. His work was destined to continue after him and to drive Germany beyond the invisible limit of wisdom to her destruction.

The greatest of the military Powers of Europe was now ambitious to play her part as a world 
Power. She wished to contend with England for the mastery of the seas and for industrial supremacy, to conquer for herself a vast Colonial Empire, to make her diplomacy, her capital, her literature, her political authority, and her example felt in every quarter of the globe; to create for herself a clientèle of as many peoples civilized and barbarous, new and old, of as many protégés and disciples as she could. William II. proposed to satisfy the new ambitions of his people by what he himself described as Weltpolitik.

These ambitions were the descendants of the older and more modest ambition which Bismarck had satisfied. But the Weltpolitik of the new Emperor, though descended from the policy of Bismarck, broke the invisible net in which Bismarck had caught all the Powers. Abandoned to her own devices and fearing that she might be attacked by Germany and Austria, Russia once more drew near to France and soon concluded an alliance with her. By this alliance France finally emerged from the Lazzaretto in which Bismarck had segregated her for twenty years and with head erect re-entered the circle of the Great Powers. The old confusion of Powers, all friendly or inimical to each other, was split into two coalitions, a change which infuriated the old Chancellor in his 
retirement at Friedrichsruhe as an outrage committed by an unskilful hand upon his masterpiece. It is at all events clear now, after four years of world war, that a close alliance of the German and Austrian Empires was a much more powerful combination than the alliance of Russia and France.

The power of Germany is usually attributed to the constitution of the Empire, but we must not forget to add the Austro-Hungarian alliance which again unified, if only in a diplomatic sense, the Germanic world divided by the war of $\mathbf{1 8 6 6 ,}$ and which, drawn ever closer, more especially after the accession of William II., doubled Germany's power without the necessity of going to war. Did it not enable Germanism, through the German dynasty of the Hapsburgs, to gain possession of Hungary and of the millions of soldiers which the Slavonic and Italian populations subject to the Dual Monarchy would be forced to furnish, to press upon Italy from the Trentino and Friuli, to threaten Russia and establish direct contact with the Balkans? Suppose that the AustroHungarian Empire were broken up, the German populations incorporated in Germany and the Slavs and the Magyars constituted independent States. Germany would then be more vast but 
less powerful than she was on the eve of the war, because she would be able to count only on the German forces, and would no longer be able to intimidate and overawe Italy and the Balkan States.

The alliance between Austria, Hungary, and the German Empire was more than an agreement concluded between two powerful States to assist each other in certain difficulties, because thereby the Germanic world effected not merely its own unity but a superunity. Nor should the advantage be forgotten which Germany could derive from the alliance between France and Russia as well as from the English occupation of Egypt in 1882 for her new designs in the East. France and England were the two Powers which Turkey had for centuries regarded as her friends, which had on several occasions helped her against Russia, her immemorial enemy. But when England planted herself in Egypt, thus separating the Asiatic from the African provinces of the Ottoman Empire, when France allied herself with Russia, Turkey was forced to seek another friend and protector. Germany, on the contrary, had never occupied or conquered a yard of Turkish territory, and in support of her new interests in the East could allege her previous disinterestedness. The 


\section{The German Peace}

reason why the influence of Germany at Constantinople grew so rapidly during the twentyfive years preceding the world war in spite of all the efforts of its rivals and in spite of all that happened, is to be found not in the victories of 1870 but in Egyptian affairs and in the alliance made between France and Russia.

According to the canon of Bismarckian policy the new policy was defective, but for a different reason. It lacked definite aims. Germany wished to be a World Power. Very good. But the world is wide, and, in the immensity of the world, this ambition looked everywhere without knowing where to stop. Where was the longed for Colonial Empire to be founded and at whose expense? In Africa, in Asia, or in South America? At the expense of England, or of France, or by a partition of the world in agreement with both those powers, or with one of the two against the other? Between I890 and 1900 the new German policy was unable to select its path and constantly hesitated between contradictory proposals.

Germany's designs at sea and her ambitions of industrial supremacy brought her into conflict with England and drove her to make common cause with England's enemies who were then France and Russia. France, however, though 
not at the moment friendly with England, hated Germany more than ever and Russia was on the point of allying herself with France. At the beginning of the new reign, therefore, Germany was making advances to England and continued to do so until she succeeded in obtaining the cession of the island of Heligoland. In 1895, however, a new power, Japan, suddenly appeared in the Far East, and having beaten China, imposed on her the Treaty of Shimonoseki, whereby she obtained the cession of Port Arthur. Germany seized the opportunity to draw nearer to the group of European Powers which was hostile to England. As Russia had designs on Port Arthur Germany took the step which Russia had desired but had not dared to take. She intervened between the belligerents, tore up the Treaty of Shimonoseki and imposed a treaty more favourable to China which deprived Japan of Port Arthur. Russia hastened to unite with Germany in her action and drew her ally France after her. For a moment the whole of Continental Europe seemed to coalesce round Germany and, since the three Great Powers of the new alliance, Germany, France, and Russia, were in conflict with England, England would have been seriously threatened if the coalition had lasted. But it did not last. When, at the begin- 
ning of 1896, Germany assumed the rôle of protector of the Transvaal in the struggle with England, France and Russia drew back. On the other hand the treaty of the Triple Alliance expired in I896. It would have been difficult to persuade Italy to renew it if Germany had quarrelled with England.

The new policy of Germany oscillated, therefore, between 1890 and 1900 in search of some definite aim. Hence the uncertainties, the rebounds and the divagations which enraged the German people and the improvisations which every now and then astonished Europe. Such was the policy of etwas erwerben, of "getting something," in China-which ended in the German occupation of Kiau Chau, the Russian occupation of Port Arthur, and so on, until, in 1898 , it seemed as if the Celestial Empire were about to be partitioned among the greater States of Europe. In the Near East alone, Germany went forward surely and resolutely, insinuating herself skilfully into the councils of the Ottoman Government, Germanizing the Turkish army through her instructors, obtaining new concessions and extending those which she had already obtained; among which was the famous Bagdad Railway, contending successfully with England and France for the Western 
hegemony in Asia, and solemnly proclaiming, through the mouth of Kaiser Wilhelm in his famous speech at Damascus on November 8, 1898 , to the three hundred millions of Mussulmans who venerated the Sultan as the Caliph, that "the German Emperor was their friend for ever"-words in which the Mahometan believed because Germany had never touched the territories ruled by the Crescent.

While, however, the new German policy sought its path throughout the world Europe seemed to have finally got rid of its turbulent past. The doctrines of authority in all the States approximated more and more closely to the principles of the Revolution and were growing weaker. How much subdued in parliaments, at elections, in the press and in the schools were the furious conflicts of the two parties which in the earlier years of the century had caused so much blood to flow in revolutions and in European wars! Towards 1900 in France, in Italy, and a little later in England, the middle classes and the masses came into power with the democratic parties. In other countries, such as Germany, the autocracy and the wealthy bourgeoisie kept the reins of government firmly in their hands up till I9I4. But in all countries the conquered party reconciled itself 
to defeat without too much bitterness, while the victorious party did not abuse its victory, and in the end they all governed, better or worse, but with very much the same objects.

Since I 848 Europe had changed beyond recognition. Who now remembered the men, the doctrines, the heroisms, the follies of that great year? Already discredited by the triumph of Germany, by the bitter rivalries of the European States, the generous aspirations of 1848 were smothered, even in the democratic countries, by the congestion of wealth. In the midst of the ruins of so many traditions and so much idealism, in every part of Europe except where, as in Austria-Hungary, the racial and linguistic struggle still went on, there was but one passion which now exalted, moved, and confounded all classes and all parties-the passion for progress which was nothing else than the new cult of steel and fire, the attainment of riches and power by means of science and machinery. After doubting for long whether to adore or to curse the potent engines of iron animated by fire which man had been creating for a century, Europe, after 1870 , had ended by being vanquished and convinced of their divine power and by believing that they were indeed divine. Though they corrupted and spoiled much that was beauti- 
ful in the old civilization, and reduced to slavery the men who had created them to be their slaves, they did in fact produce abundance, the abundance longed for by the multitudes which had for centuries been stinted!

Little by little every one, men, women, rich and poor, great and small, abandoned themselves to their power. They served night and day, so inebriated with their slavery that they called them by fine names, and proudly displayed their fetters to the astonished peoples of Asia as if they had been splendid ornaments which were a glory for the human race. They sacrificed to these new idols everything, such as reason, beauty, and the nobility of life-which had been admired and sought after for centuries. Every year public and private expenditure, the needs of all classes, the thirst for gain and useless consumption increased, and, with these, a satiety even to nausea among all civilized peoples and decent citizens, for otherwise what could be the object of increasing production? The more the number and the power of the machines increased the more hours men had to steal from sleep and rest, the more they had to exhaust themselves in the mad struggle for increased production and consumption. How proud they were, nevertheless, when one of their 
number invented some new, more powerful and more rapid machine which would increase the universal torment! And with what garlands was the fortunate inventor crowned!

The German People set an example to all nations of fervent pursuit of the new cult. Every year their population grew and soon left France far behind in the rivalry of numbers. They laboured indefatigably to secure the lead in metal-working among all the Powers and in 1900 they had already smelted eight million tons of iron against England's nine. They exaggerated the principle of increasing quantity at the expense of quality, and were determined to conquer in industry as they had done in war by force of numbers. To produce, produce, and still produce; to increase without rest the old industries and to multiply new ones, either original or copies; to eliminate handiwork and human skill by means of machinery, and nature with its parsimonious perfections by means of drugs, dyes, and chemical substitutes; to make everything cheap by increasing its quantity; to oblige men to live in plenty and consume largely while deceiving them with clever falsifications, sold sometimes at a loss; to tempt savages and civilized races, old peoples and new, by cheap and flashy goods, imitations which appealed to the 
mania for novelty - all these prosaic operations of commerce underwent a sort of transfiguration in Germany and became a national mission which it was the duty of the State to help and to direct.

Between 1900 and 19I4, Europe and America vied with each other in admiring this people which, after winning three wars in less than ten years, had grown by nearly a third in little more than three decades, which had launched the second mercantile fleet and the second navy in the world, which had reached the head of the metallurgical industry in Europe-in I9Io Germany produced I 5 million tons of iron, England Io millions, and France 4 millions; which was disputing England's industrial supremacy and whose diplomatists, merchants, commercial travellers, professors, books, bankers, ships were making themselves felt in every quarter of the globe! Democracies and aristocracies, monarchies and republics vied with each other in zeal for the new religion. All admired and took Germany for a model even when there was the gravest reason to distrust her. Democratic and conservative parties were quarrelling for the most part about words; there was only one point of real difference between them. The democrats wished to unite the cult of fire with the cult of peace; the conservatives held to the mili- 
tary tradition of the nineteenth century. The parties and the governments who wished for a world peace felt a certain aversion from the Power which had three times attacked its neighbours and had imposed on Europe unlimited competition in armaments. But Germany had sheathed the sword for so many years and had sworn so emphatically not to draw it ever again! Thus her growing power helped Germany where the conservatives were in power without damaging her in the countries which were under the control of too forgetful and trustful democrats.

Little by little, without knowing it, sometimes even against its will or even while actually cursing Germany, Europe became Germanized. This was not due to the somewhat antiquated prestige of the German arms, but because in the new quantitative, mechanical, and democratic civilization only numbers could fill the now innumerable barracks, express the will of the people as the suffrage was enlarged, or supply the hands and the customers which were required by industry on the grand scale. The nation which had best understood how to temper and to use the new weapon of numbers necessarily appeared to be a model nation as in the strife for power and riches the old ideals, which aimed at quality rather 
than quantity and perfection rather than power, became gradually obscured. Numbers, however, were now represented by the numerous classes, the bourgeoisie and the people. The quantitative civilization therefore grew with the growth of comfort and education, and with the power of the middle class and of the masses, more rapidly in the States which had representative government, but more or less in all. The growing power of these classes is one of the most striking phenomena in the history of Europe during the last half century, and it was universal everywhere, Russia herself being no exception to the general rule. The effects, however, were different in AustriaHungary, in the parliamentary democracies of the West, and in Germany.

In Austria-Hungary the number of enemies of the State increased because the new spirit reinforced the opposition of the nationalities to the hegemony of the Germans and the Magyars in those parts of the Empire in which the Hapsburgs possessed no indisputable title of legitimacy but force, as was the case in Bohemia, among the Southern Slavs, and in the Italian provinces. In Bohemia industry was becoming wealthy and the schools were bringing up a middle class which was no longer content to figure as clients, however well 
remunerated, of the German aristocracy of Vienna or the Germanized aristocracy of Prague. The same revulsion of feeling had taken place, though in a less degree, among the Southern Slavs. The national movements in the Austrian Empire were opposed not only to the German and Magyar hegemony, but also to the aristocratic constitution of the Empire which was the foundation of that hegemony. Hence there was a threatening upheaval of parties, of peoples, and of races, which filled parliament and the States with confusion and shook the Empire to its foundations. In the democratic parliaments of the West, on the contrary, the leaders and the parties of the middle and popular classes had been easily and promptly absorbed into the Government, though not with all their views. After 1900, especially, they had gained a large share of power, in France through the Radical party, in Italy under the long dictatorship of Giolitti, in England in the first Liberal ministry of the reign of Edward VII. In all three countries there was a concurrent growth of the influence of the Labour and Socialist parties. These influences weakened the State, though they were not hostile to it as in Austria-Hungary, and even supported it by their contradictory aspirations. It was characteristic of the middle and 
lower classes before the war that they confounded the principles of the Holy Alliance and of the Revolution so completely that they were mutually cancelled out. All over Europe except in Germany these classes were averse to militarism and wished only for peace and secure prosperity. They were also liable, however, to occasional attacks of bellicose frenzy, such as the hysterical convulsion of jingoism which swept through England at the time of the South African War or the Imperialistic exaltation which in I9I I drove Italy to the Tripolitan coast. A series of governments began, called democratic, progressive, radical, and so on, which spent money freely, were not too rigorous or authoritarian, and did not insist too much on respect and deference. Their leaders might on occasion be severely criticized and abused. But the nations had for centuries been too much accustomed to obey not to desire the benefits of strong government; hence their admiration for the German State system, and their mania for imitating many German institutions which were living and fruitful in Germany but which, when transplanted to democratic States, languished or became positively mischievous.

In Germany, on the contrary, while the growing numbers of the population reinforced the socialist 
party, the middle classes reinforced the government because until 19I4 they remained, with some hesitation occasionally, submissive to the dynasties, the aristocracy, and the bureaucracy. The reason for this was that the government looked after their material interests, flattered their pride, and excited their cupidity and ambition. The more Germanized Europe became, the more it was weakened in comparison with Germany, because it was involved in a contest in which Germany had all the advantages. France lacked men, Italy coal and military traditions. Russia had a scattered population, no industries, and no education. England was wanting in armies and administrative efficiency. Thus, while other peoples made themselves miserable with the thought of their imperfections, the German tribes exulted in the belief that they were the masterpiece of the universe, and got into the habit of despising other nations. France was corrupt, Russia barbarous, Italy frivolous, England out of date. Nor were there wanting people who encouraged these sentiments. About 1895 there began to appear in great numbers in Germany books and pamphlets demonstrating that the German people, being the most capable, had the right to take from other peoples anything that they thought 
necessary to enable them to live generously and to dominate and remake the world in their own image. Numerous and powerful societies made it their object to diffuse these doctrines among the educated middle classes, whose devotion to the Empire and the Emperor was continually stimulated by the hopes excited by this teaching, hopes which, in spite of the frequent oscillations of the Imperial policy, founded themselves confidently on the new Bismarck, the man who would raise to undreamed-of heights the power of Germany already so great in Europe. Meanwhile they did what they were told.

Thus Europe, always intent on increasing its riches, always at war with itself and contradictory in its wishes, exhausted itself in feverish unrest. Between 1895 and 1905 almost all the European States, like Germany, and partly in deliberate imitation of Germany, tried all sorts of new combinations which sometimes appeared certain to alter profoundly the political situation, but which in the end effected little or nothing. The fear of war which had prevented Europe having a minute's peace between 1870 and 1890 was almost gone, and all governments wanted peace. Was it not absurd, then, to continue the unlimited rivalry of armaments which weighed so heavily 


\section{The German Peace}

on all States? Nicholas II. in 1898 invited the States of Europe to concert disarmament, and a great conference met at The Hague which debated and deliberated the question for months and ended in the signing of protocols. Then the struggle began more bitterly than ever. Germany, intensifying her exaggerations of the principle of the nation in arms, introduced two years' service, did everything in her power to increase her industrial production, to perfect her old engines of war and to invent new ones, and her shipyards worked day and night to increase her fleet. Nicholas II., after having proposed a league for the peace of Europe, yielded to the insatiable hunger for territories which possessed his government and undertook a ruinous and disastrous war with Japan for the possession of Corea, as if the Russian Empire was not large enough already.

A new crisis was brewing in the East where the Christian populations, still groaning under the Turkish yoke, were agitating, as Italy had agitated between I8I5 and I848, for the right to live. Crete had rebelled and from this rebellion developed a war between Greece and Turkey in 1897 . But the affairs of Macedonia were even more disturbed, for there Bulgars, Greeks, and Serbians, secretly supported by their national governments, 
rebelled against the authority of the Sultan and at the same time waged a war of mutual extermination. What did Europe do? In 1897, Austria and Russia came to an agreement guaranteeing the status quo whereby they pledged themselves to leave the disease without a cure. And the only thing that the rest of Europe troubled about was whether this agreement would weaken or strengthen the Triple Alliance. Italy, which for some time had been once more drawing nearer to France, was somewhat eclipsed, and made a special agreement with Austria on the subject of Albania. France, which during recent years had been the object of the lavish courtesies and attentions of Germany, seemed on the point of a mortal quarrel with England about Fashoda. At this time Germany and England were friendly and concluded a secret treaty about the Portuguese Colonies and another treaty guaranteeing the integrity of China and freedom of trade at the river and maritime ports of the Celestial Empire. In England, indeed, very influential personages were actually discussing a plan of alliance between England, Germany, and America. In Italy, finally, Prinetti, the first Foreign Minister of Victor Emmanuel III., who had now ascended the throne, was extremely hostile to the Triple Alliance. The 
King's first official journey was to St. Petersburg, and one of the first important acts of the new reign was the agreement of 1902, whereby France left Italy a free hand in Tripoli and Italy left a free hand to France in Morocco. Italy and France forgot the collision over Tunis and forgave each other their reciprocal causes of offence during the past twenty years, dividing between themselves in idea on the map territories which neither had any idea of occupying at that time. This agreement did not prevent Italy from renewing the Triple Alliance in 1902. This step did not disturb her good relations with France who, on the contrary, officially declared herself satisfied, nor did it prevent the renewal in Italy of the Irredentist agitation which had for so many years been quiescent.

The alliances and agreements of the European Powers were now very numerous and complicated, and the field for understandings and contests much increased. The possible combinations were so many, so various, and often so vague and therefore so easy to bring about, all the States were so anxious not to disturb the peace, that the old rivalries seemed to have subsided into a constant movement of new combinations which were all the easier to form, as practically all of them were 
more concerned with seizing future than present advantages. The future was like an unexplored continent, easy to partition in a friendly way precisely because its extent and boundaries were little known. The old enmities, however, were not dead; they went on smouldering under the protocols which reconciled the Powers to each other by dividing up Asia and Africa among them in the future. The nation which stirred the fire and reawakened it below this heap of treaties was Germany, the strong nation which regarded itself as first in the world, and destined to become a world power.

When he ascended the British Throne, Edward VII. made it his business to rouse England which was slumbering profoundly while Germany in the darkness was sharpening a knife with which to stab her as she slept. Alarmed by the power and the ambitions of Germany, Edward VII. wished to counteract them by a sincere and durable understanding between England and France. He was successful, and in 1904 England concluded with France an agreement liquidating all the Colonial questions which had divided the two countries for so many years, and which a few years before would have seemed impossible. But the time was ripe for it. Russia had been weakened 
in Europe by the war which she was fighting against Japan, and France had to seek for some reinforcement of the Russian Alliance in order to maintain the equilibrium of Europe. She was therefore at the parting of the ways of reconciliation either with England or with Germany. The memory of Alsace-Lorraine barred the way to a reconciliation with Germany, and France and England came to terms. The result was that France, as practically the ally of England, actually the ally of Russia, and the friend of Italy, suddenly found herself, to her own surprise and that of Europe, once more the pivot of the great combinations of world policy and in the position to which Germany had aspired with impetuous ambition for fifteen years. The game which Bismarck invented of embittering colonial rivalries in order to dominate Europe had so turned out that in the end it was France who, having risked little or nothing, was the winner. Germany did not take this caprice of fortune well. She lost her temper and launched her first defiance at Europe.

The historic crisis which came to a head in the world war began in the spring of 1905 with the famous landing at Tangier and the still more famous speech of the Emperor William on that occasion. When France reconciled herself with 
England in 1904, she had abandoned Egypt, and England in return had resigned all interest in the affairs of Morocco in favour of France. By suddenly appearing in Africa in the guise of the Protector of Islam and of the independence of Morocco William II. intimated to France and England that their agreements were useless scraps of paper unless they were countersigned by Germany. This was an open challenge. It was not accepted by France and England because, Russia being paralysed, they felt themselves to be too weak on land. Germany on her side did not push things to the point of going to war, because she knew that she was the weaker party at sea. An agreement, therefore, was reached. The Entente gave way by recognizing that not only England and France but the whole of Europe had the right to decide the fate of Morocco. Germany was satisfied by the summoning of a European Congress at Algeciras at which several European Powers were to be represented who had as much interest in Morocco as in the planet Mars. The Congress met, and, in order not to irritate Germany while not allowing her to win at all points, drew up a highly ingenious international statute recognizing that France and Spain had special rights and privileges in Moroccan affairs, but limiting 


\section{The German Peace}

these by so many restrictions and obligations in favour of the other Powers that the Treaty became one mass of quibbles which bad faith and bullying could turn to advantage at any time.

From this ferocious challenge dated the beginning of the troubled twilight of the German peace. How strange and disturbed these years now seem as viewed from the bottom of the abyss into which we fell! Riches increased like a flood of slime covering the world. There were no doubters now; steel and fire were indeed the new divinities of plenty and power. All the fetters which had at first encumbered the advance of the machine were broken. Machines grew more feverish in their speed until finally they took flight from the earth and appeared to have vanquished the laws of gravitation and the parsimony of Nature, and to have annulled time as well as space. Intoxicated by their successes, men worshipped and slaved for them more than ever. Kings and workmen, aristocrats and bourgeois, poets and philosophers crowded about the idols and their priests, no longer fearing them but admiring them precisely because, by means of the power which had apparently no limits, they fondly hoped to set at nought the boundaries beyond which thought and morals and social organization cease to be possible. The 
more riches increased the more great and small felt themselves to be in want; they bowed themselves to new and even more arduous labour in order to slake the thirst which returned upon them as they drank, and they disquieted the world with an unrest which grew more bitter with every effort that was made to soothe it. From this universal restlessness, from pride and overconfidence, ignorance and half-knowledge, there developed among the middle classes and in the mass of the people a spirit of hatred, ambition, and unstable delusions often self-contradictory not to say insane. To this the upper classes, divided as they were among themselves, désorientés and infected with the same megalomania themselves, could only oppose an indulgent acquiescence, when they were unable to use force as in Russia they attempted to do. Thus the States, unable to resist these impulses or to push them to their logical conclusions, lived from hand to mouth, juggling with opposing principles in order to please everybody, doing everything by halves, and when they wished to carry out some measure of reform copying some German institution.

After reconciling herself with France, England skilfully took advantage of the defeats suffered by Russia in the Far East in order to reconcile 
herself also with the Muscovite Empire and to reply to the challenge thrown at her and France by Germany in 1905 by opposing the Triple Alliance with the Triple Entente. She could not, however, go further and equip an army for intervention in a Continental war. The nation did not want new things, new burdens, and new sources of anxiety. Many by tradition still felt more distrustful of France than of Germany. The Liberal and Radical party which was in power wished to limit armaments and were under the illusion that they could come to terms with Germany whence they had borrowed several social reforms such as workmen's pensions. France was convulsed with extremely bitter political and social conflicts on the subject of reforms proposed by the radical party, some of which introduced into France institutions in force in Germany, such as two years' military service, workmen's pensions, income tax, and State railways. She was tortured by doubts whether the time was not come to forget the two daughters torn from her in I87I, and to make peace with their ravisher, or whether she should continue to cherish in her heart the flame of implacable resentment. The Treaty of Algeciras, which had been drawn up with so much trouble, became a source of torture to her. In 
each of its articles Germany discovered every day some new pretext for quibbling and bullying, for new claims and for open or covert threats which exasperated the fiery Gallic temper. Even war was preferable to submission to such tyranny! But the threats were interspersed with amiable words and smiles, protestations of friendship, and veiled invitations to conclude a definitive agreement which, by uniting the two greatest States of Continental Europe for peace, would bring peace to the whole world. France, therefore, feeling herself every year more overpowered by the numbers of her enemies, asked herself whether she was wise to persist in a hatred which was vain and indeed dangerous both for herself and for Europe, since the power to gratify it was lacking.

Impressed by the defeats of Russia, Italy had somewhat cooled in her desire for new combinations, and, while she did not cease to cultivate the valuable friendship of France and England, she decided to regard the Triple Alliance as a permanency and did her best to make friends with Austria by damping down once more the Irredentist agitation. But though she wished for peace and, in order to conciliate the masses, did her best to limit her military expenses and obligations, she had attached herself to an alliance which after 1905 


\section{The German Peace}

was preparing for war. Russia, finally, was at grips with Revolution after the Japanese war, and was reconstituting her army as best she could. While, therefore, she was united to France and England owing to her need of money and assistance, she drew nearer to Germany owing to her fear of the Revolutionaries.

One Power alone stood solidly entrenched behind the triple fortifications of a monarchical, aristocratic, and military system, a resolutely aggressive national pride, and a megalomania destined to increase till it became suicidal. In the nine years between 1905 and 1914, between the first and the final defiance, Germany alone among the great States of Europe was not weakened and disunited by the progressive development of industry and the growing power of the middle classes and the mass of the people. While in other States armaments were the greatest burden on the governments which had great difficulty in overcoming the doubts and reluctance of legislatures when there was any question of increase of the Army or the Navy, Germany continued resolutely to increase her army as much as she could, and to re-equip it with new and more powerful weapons. The Army was more and more closely associated with Industry, elsewhere so 
distrustful of the military element if not actually hostile to it. Industry was incited to invent new weapons and instruments of war of unheardof power. The Army, on the other hand, was secretly trained to act in the forthcoming struggles as the armed agent of Industry.

Other States were content to follow, some months later and against their will, the impetuous initiative of Germany. While in all other European nations, Trade, Industry, Finance, Education, the Press, and Diplomacy fulfilled each its proper function without reference to the rest, the German Government spared no pains to gather up all these separate activities and unite them in a single concerted activity whose object was to serve the ambitions and increase the power of Germany. France, England, and Russia were intimidated and took pains not to offend and even to conciliate this restless Power. England sent peace missions to Germany to propose a partial disarmament. The Czar followed with complete docility the advice of William II. and the Russian government allowed itself to be more completely overcome every day by the German invasion. In France the socialist party was offering the German people forgiveness and forgetfulness of past injuries. But throughout Germany never ceased to try the patience of 
France by quibbling over the Treaty of Algeciras and seizing every opportunity of raising diplomatic difficulties of every sort. And when a new opportunity arose of defying the Entente, this time in the person of Russia, she did not let it slip.

This opportunity arose out of the Eastern Question. In Macedonia things were every year going rapidly from bad to worse. The Christian population never ceased to rebel against the Sultan and at the same time continued to exterminate each other with ever-growing ferocity. The Turkish Government was powerless to restore order. The Balkan States were all agitated, each wishing at the same time to help its nationals in Macedonia and to prevent other States from doing the same. The Powers of Europe, fearing a catastrophe and suspecting each other, intervened with mild expedients such as the organization of a European gendarmerie, which wounded Turkish self-esteem without pacifying Macedonia. In the end the Turkish Army, humiliated by European intervention, irregularly paid by a clever but avaricious Sultan, who was too astute and too confident in his own astuteness, mutinied. In July, 1908, a military revolution at Constantinople deposed Abdul Hamid. This revolution, which 
had been planned in the Masonic Lodges of Salonica by the party of the Young Turks, declared itself to be a zealous disciple of the French Revolution, and announced its intention of regenerating and Westernizing the Empire by means of representative institutions, of freeing all the former subjects of the Sultan, giving autonomy to all the provinces, and granting equality of rights and duties to Christian and Moslem alike.

The Western democracies were delighted, imagining that in the East feudal Germany had lost the toilsome acquisitions of twenty years' hard work. But the Turkish Revolution was really only the beginning of a European crisis at the end of which Germany was more powerful than ever in Turkey. The Austro-Hungarian Empire had long been awaiting its chance to show that it was still strong enough, not merely to keep what it had, but to take the property of others. The Turkish Revolution provided the opportunity to annex Bosnia and Herzegovina, the two Turkish provinces which the Congress of Berlin had handed over to Austria to be "administered" under the sovereignty of the Sultan. Since all the provinces of the Ottoman Empire now formed part of a constitutional State, the Austro-Hungarian Government recognized that Bosnia and Herzegovina 
had the right to be equally fortunate. Accordingly they declared themselves prepared to receive the provinces on an equal footing with the rest of the family of States within the Empire. But how could this be done until they were annexed? The pretext was ingenious, but also sophistical, and at first everybody thought that there would be a fierce struggle between the Young Turks and the Central Empires. But, after making some difficulties and receiving certain compensations, the Young Turks resigned themselves to the sacrifice, and the conflict which did arise was between Slavs and Germans.

The little Kingdom of Serbia was distressed by the fate of Bosnia and Herzegovina inhabited by men of Serbian race, protested, threatened war, and stirred up Russia whose eyes were again turning towards the Balkans and the Slav' peoples there who were threatened with Germanization. For a moment it seemed as if little Serbia, backed up by Russia, was about to sling a stone at the Austrian Goliath as the tiny Kingdom of Piedmont supported by France had done fifty years before. But Germany intervened and, as in 1905, launched a defiance, threatening Russia with war. For the second time the Entente gave way. 
Germany was virtually the dictator of Europe, for France, England, and Russia had not dared to resist her threats with their united strength. England was, however, posted in Egypt. Russia was the immemorial enemy of Turkey, and France the loyal ally of Russia. Between the rival European Powers the Young Turks did not hesitate long. They made a closer league with Germany than the old Turks had ever done, for Germany was the strongest power, and had never touched Ottoman territory. At the same time they organized a dictatorship for themselves in the Empire under the semblance of constitutional government. Dictator of Europe, preponderant in the East, every day more populous, more opulent, and more pushing, Germany was admired, envied, and feared by the whole world. She might well have been content and proud. Instead of that, she was afflicted since she had begun to defy Europe, with a kind of irritability recalling her state of mind between I8I5 and I866, as if she had gained nothing in reaching the summit of power and wealth in the course of fifty years. As in her earlier days, she was obsessed by delusions of persecution and accused all other nations of hating and threatening her. Now as before she regarded herself as ill-treated and humiliated 
by fate because she did not possess a colonial empire as great as those of France and England. Now, as before, and even more than ever, being the stronger, she vented her anger at imaginary wrongs by despising all nations with rancorous arrogance and more especially France. Such was the inexorable curse of a Power which, relying on numbers and on quantity, set itself no limits and for which every goal attained was merely a point of departure for something else! Germany, however, was strong enough to make all Europe suffer for her malady, and, driven on by the restlessness in the mind of her people and emboldened by the weakness of her adversaries, the German government in I9I I launched the third and most menacing defiance-Agadir.

Once more France had to sweat blood in order to resist threats and flatteries, to curb her most just resentment and at the same time to fight the delusion that she could placate the enemy by reconciliation. The Third Republic has made many mistakes, but Posterity will credit it with the tremendous merit of having saved Europe from Germanism by its perseverance during these years of passion in the moderate policy of never letting itself be drawn by German provocation into assuming before the world responsibility for a 
new war, of yielding to the utmost possible while never going so far as the reconciliation for which Germany wished and which would have made France the ally of her former enemy. It was a difficult and thankless policy, exposed to all the derision of malevolence and the criticisms of the logician, a via media between war and peace which displeased impatient people in both parties, those who did not recoil from the dangers of war, and those who wished for a definitive reconciliation.

It would have been a disaster if the Republic had yielded to the arguments or the reproaches of either. If it had gone to war, however just its quarrel, it would have been abandoned to its powerful enemy by the distrust and malevolence of which it was still the object all over the world at the beginning of I9I4, and France would assuredly have been destroyed. Forty years had not taught Europe to realize that France was the keystone of European equilibrium and Europe would undoubtedly have left her to perish, only to repent bitterly when it was too late. On the other hand had France allied herself with Germany in the mistaken hope of placating her enemy, she would have been at Germany's mercy, and Germany would at once have become mistress of Europe and of the world, because the coalition against 
which German ambitions were shattered could never have been formed without France. What could England and Russia have done alone? But if France saved Europe by patient waiting and remembering, the patience, the waiting, and the remembering were never so difficult as they were during the diplomatic negotiations which took place between France and Germany in I9I I because Germany was never so provocative and never so full of blandishments. On this occasion, however, Germany again did not dare to push matters to extremities. The protracted dispute about Morocco was to all appearance finally settled by an agreement under which Germany gave up Morocco to France while in exchange France ceded part of the Congo to Germany. Although the agreement was equally displeasing to the French and to the German public, the world for an instant hoped that it might again breathe freely. Quite suddenly an unexpected development of events seemed to upset the situation to the disadvantage of Germany. The agreement between France and Germany and the protectorate of Morocco about to be assumed by France profoundly disturbed Italy, and the Government was obliged by public excitement to declare war on Turkey in September, I9II, in order to re-estab- 
lish the balance of power in the Mediterranean, according to the agreements of 1902 by the conquest of Tripoli. But the war between Italy and Turkey, which lasted over a year, ended by stirring up the Balkans. Serbia, Montenegro, Bulgaria, and Greece saw that the hour had come in which, by uniting, they could cut the Gordian knot of the difficulties in Macedonia. They formed an alliance and attacked Turkey, drove the Turks out of Macedonia and Thrace, and pursued their defeated armies to the gates of Constantinople. Though the Central Empires succeeded in breaking up the Balkan League by inciting Bulgaria against her allies at the division of the spoils, Germanism seemed by the middle of I9I 3 to have suffered disaster in the East. The Turkish Army, trained and armed by Germany, had been annihilated by four Balkan armies which nearly all had French instruction and French weapons. Austria-Hungary-and with Austria-Hungary the whole German world - ceased to have a frontier with Turkey. Though they were once more divided by implacable enmities, the Balkan States were interposed as a barrier between Germany and the East, and of these Serbia, the enemy of Austria, had been almost doubled in territory and population. Finally the victory of the Serbian 
arms had excited the Slav populations of the Southern provinces of the empire, and had awakened a new spirit of opposition against the governments of Vienna and Budapest, and new hopes and illusions of a happy future.

This reversal of fortune was all the more bitter because the enemies of Germany could enjoy and exploit it without having moved a finger. For the defeat which had overtaken her, Germany had herself, her own ambition, her own audacity, and her own strength to thank. Public opinion was exasperated by what appeared to be a new injustice of Fate and thereupon the German Government took an irrevocable decision to annihilate Serbia at the cost of a European conflagration. Founded on force, the German Empire had recourse to war as to the judgment of God which would prove to a doubting Europe that she possessed legitimate title to domineer over all the peoples of the continent who were either too old or too young.

For the fourth time the plan of campaign, though on an immeasurably larger scale, was retraced on the model of the successful wars of I863, I866, and 1870 . As in 1870 a pretext was sought in a controversy with which Germany could say she had nothing to do. Then it was the election of the King of Spain; this time it was 
the question which arose between Serbia and Austria on the subject of the Sarajevo murders. In 1870 when the French Ambassador at Berlin sought the explanation of the German Government he could not see the King, who was at a watering place, or his Prime Minister, who was in the country, but only high officials whose answer was that the matter concerned Spain and Prussia knew nothing about it. The French Government therefore had to go to Madrid. In I9I4 the Emperor was in northern waters when Austria sent her outrageous ultimatum to Serbia. His ministers replied to the Entente diplomatists that they knew nothing and could give no answer, that the matter concerned Austria, and they should consult Vienna. As in 1870 so in 19I4, there were the same tergiversations, oscillations, and ambiguities intended to deceive the adversary, to keep him in suspense, anxiously hoping for an agreement, to prevent him from resolutely preparing for war while Germany made her final arrangements. The same blandishments, the same tricks, were repeated to reassure the Powers which might intervene and to prevent a coalition. And in 1914 as in 1870 no sooner were her armies ready than she dropped the mask. The German Army swooped with a furious onslaught on France, 
so as to terrify Europe and by producing a fait accompli to destroy all possible combinations before they could be formed.

But the fourth time fortune was weary of being tempted by the same devices. The surprise failed, and there was time to form the coalition. For this reason, it will be the immortal glory of France that in I9I4 she was able to stop the German invasion at the cost of her best blood. England had time to prepare her army. Italy, Roumania, and Greece had time to intervene. The United States had time to bring to the rescue of Europe, threatened with destruction by the defection of Russia, the last reserves of civilization.

Thus the world was saved, but at what a price! After forty-four years, the prediction, which seemed to be falsified by events, that the German victories of 1870 would desolate the world with terrible wars had come true. Instead of being scattered over a series of years, these wars burst all at once on the world and on the treasures it had accumulated during the protracted peace. 


\section{CHAPTER VII}

FROM THE HOLY ALLIANCE TO THE LEAGUE OF NATIONS

THE world war has lasted longer than the most sombre predictions anticipated. It has destroyed an enormous number of human lives, and an incalculable sum of human riches. It has exhausted the moral and economic strength of all the States of Europe, those of the victors no less than those of the vanquished. Two generations will perhaps be needed to repair the ruin wrought in the last four years. In compensation, however,- precisely because it has lasted so long and destroyed so much,-it has solved the problem which ever since the French Revolution has tormented Europe. It has finally settled the conflict between Divine Right and the Sovereignty of the People, between the dynastic principle and the principle of nationality, which filled the whole history of the nineteenth century. In I9I4 there were still two Europes; in I9I9 there is only one. With the Russian and Austrian Empires fell Divine Right 
and the dynastic principle and even the German Empire, should it survive the crisis through which it is now passing-as seems very unlikely,-will not by itself be able to do anything to restore that vanished world. The principles of popular sovereignty and of nationality have triumphed.

The victors, therefore, are now in a position to solve definitely and radically all the questions which have distracted Europe for a hundred years, even those which five years ago seemed insoluble. They have a free field; the past is liquidated and they can construct de novo on clear and precise principles a Europe which is coherent and concordant with itself. The opportunity is unique, immense, almost miraculous, and the victors will show themselves unworthy of their victory if they let it pass or fail to make proper use of it. Have we not seen that all the ills of Europe have arisen from having tried for a whole century to reconcile the two contending principles by forced, false, and partial solutions? The hour of expedients is past, and the hour of final, because coherent, solutions has come. The future of Europe and of Western civilization depends on the energy and the intelligence which is brought to bear in carrying out this duty.

It follows that now is the moment to render 
justice to all the European peoples who were victims of Germany, of Austria, or of both, beginning with Italy. Many false stories have been spread throughout the world about Italy's share in the war. Beginning with the so-called betrayal of her old allies, her calumniators go on to say that she was contaminated by imperialistic ambitions, and full of crooked plans. The reply to all these charges will be found in geography and the history of the nineteenth century as summarized in this book. Look on the map at the countries which Italy is united in claiming as her reward in this war-the Trentino, Trieste, and Istria. Part of the nation would like to add Dalmatia and its islands and a protectorate over Albania. They hope that, if the fall of the Ottoman Empire results in the partition of Asia Minor by which the European Powers intend to profit by establishing Protectorates or by any of the other expedients of domination familiar to the old diplomacy, Italy will have her share. But the Italian people are not in agreement about these claims, because influential groups maintain that the national, historical, and strategical reasons which justify the former demands do not cover Dalmatia, and they are very reluctant to involve Italy too deeply in Eastern affairs. 


\section{To the League of Nations}

In any case, even if Italian ambitions are measured by the larger list, they should be compared with the sacrifices she has undergone and the risks she has run. Though Italy has not lost so many men in the war as France, England, Russia, or the enemy empires, she has yet lost a very large number-enough to leave a terrible memory of this war in the minds of several generations. Admitting, however, that the number of Italian lives lost is less, let it be remembered that none of the allied countries has suffered so much from war privations as Italy, or has more seriously compromised the national fortune for generations, if not for centuries. Italy has no coal, little petroleum and iron. Italy is over-populated because, notwithstanding the fertility of her soil and the industry of her people, she cannot produce enough to feed her people. When the war broke out, Italy, though she had worked hard and not unsuccessfully for thirty years, was very far from possessing factories and skilled labour sufficient for carrying on a war which made so much use of machines. The war therefore impoverished. Italy to a greater degree than the other allied countries; it deprived her of a greater number of the commodities to which everyone had become accustomed in peace time, and imposed on her a greater proportional expen- 
diture of labour and money because she lacked almost all the raw materials necessary for war industries. All things considered, the war will cost her not less than fifty milliards, or little less than half the estimated national fortune. Add the debt which the nation had already contracted in order to make itself a nation and the continuing obligations such as pensions which will arise out of the war, and it will be seen what a heavy burden will be imposed on the patrimony of the country.

Nor has the war brought Italy any of the compensations which can be set off against the losses and the heavy expenditure incurred by France and England. England received a high price for freights, for coal and iron, and for many of her manufactured goods. France has received the fabulous sums expended by the British and American armies on the continent. Italy on the other hand was deprived by the war of all her richest sources of revenue. Her export of merchandise and articles of luxury was suspended, likewise the tourist traffic. Moreover it should not be forgotten that, in the thirty years which preceded the war, Italy had traded chiefly with the Central Empires from which she obtained most of the manufactured articles which she needed, and to 
which she sold the greater part of her high-priced agricultural products of which she had abundance. By helping with her armies to destroy the Central Empires Italy has deranged the whole of her foreign trade.

Let us now place in the other scale the acquisitions she hopes to make in compensation for these great sacrifices. The territories included in the list put forward by those who demand the most do not comprise a population of more than two millions, leaving out of account Eastern aspirations which are at present too vague to reckon and may never materialize at all. Can a nation which submitted to such sacrifices for so modest a return be suspected of selfish designs and immoderate ambitions, even if it be admitted that a section of public opinion is mistaken in applying the doctrine of nationality to a part of these small territories? If this is imperialism, it is the maddest that has ever appeared in history. No: to suspect Italy of imperialistic ambition is to insult her century-old misfortunes, the culmination of which came in the supreme sacrifice which she has now made. The history of these misfortunes as narrated in the foregoing pages explains what has been Italy's position in the world war and the reason for that sacrifice, which she made de- 
liberately when she decided to take her share in the conflict.

For ninety-nine years up to and including I9I4 (not merely until 1859 as is sometimes supposed) Italy had been the victim of the Congress of Vienna, or rather of Europe which in I815 left her divided and disarmed in the power of Austria. The readers of this book know how desperate was the state to which the Austrian régime reduced Italy, how impossible it was for her either to live under the preposterous governments which Austria supported or to reform or abolish them, what the elite of the people who were the eldest children of European culture endured for nearly half a century, seeing themselves reduced to be miserable serfs of a German Empire, separated from the main currents of Western civilization, buried alive in a dead past. They know that the Revolution of 1848 , after raising the hope that her sufferings were nearly over, ended in a disappointment, and that the war of 1859 , owing to the distrust, the hesitation, the rivalries and the scruples, not always disinterested, of Europe, seemed for a moment to be about to make her position even more impossible than before. They know that, in order to avoid an irreparable catastrophe, Italy had to use violence to break these scruples and hesita- 


\section{To the League of Nations}

tions, and how she did so. They know that even the wars of 1859 and 1860 left the task only half finished, and that, in order to achieve complete independence, Italy was forced to ally herself with Prussia in 1866 . They know that, with the war of I866, Germanism took a decisive step towards the hegemony of Europe, but that owing to the doubtful loyalty of Prussia, the timidity of Europe, and some errors of her own, Italy was not even then able to secure her own natural frontiers, complete national unity, and secure boundaries. They know that when the balance of power in Europe was broken by the war of 1870 , Italy could not by herself resist the threats of Austria and maintain her freedom as France, an older, stronger, and more warlike country, succeeded in doing against Prussia, but was constrained by the weakness of her frontiers and her youthful inexperience to accept the alliance of Austria and Germany. They know, finally, that this alliance for thirty-two years disguised beneath the appearance of a compact between equals a final remnant of the old Austrian domination which had survived the war of 1866 and was neither more nor less than a chain which bound Italy to the Central Empires to her own damage and that of Europe and to the advantage of Germany and Austria. 
By arranging the affairs of Italy-as was done by the Congress of Vienna-and by constantly failing to solve the Italian Question which it had itself raised, Europe caused the eldest heir of European culture to waste nearly a century in the misery of a terrible internal crisis, and at the same time dealt itself a deadly blow. From I8I5 to I9I4, the Italian Question was a calamity for all the States of Europe, except Germany alone, for whom it was a source of gain. How right Bismarck was when he said to Nigra that if Italy did not exist it would have to be invented! If Austria was the torturer of Italy, Italy has been the ruin of Austria. Because she wished to possess Italy, Austria ruined Germany, and has now fallen herself. The Italian Question was one of the causes of the fall of the second Empire, and it would be difficult to enumerate all the difficulties encountered by the policy of the Third Republic owing to the adherence of Italy to the Triple Alliance, an inevitable consequence of leaving unsolved a residue of the Italian Question in the shape of the unredeemed territories.

Italy took up arms in 1915 . She paid the terrible price exacted by this most terrible of all wars to remove this remnant and to gather up all the populations which are Italian by speech, by history, 


\section{To the League of Nations}

and by culture witinin the circle of her strong natural frontiers. In Italy, as all over the world, the majority of the people ardently hope that this horrible war will be followed by an orderly and secure peace under which the independence of peoples will be protected no longer by mountains, rivers, and artillery, but by respect for right and justice. No one, however, can foresee with certainty what the future has in store, and whether or not Europe will succeed in staying the hurricane of violence which has broken out. Two opposite conjectures seem reasonably possible. Every page of history teaches us that violence is like fire, a good servant but a bad master. Occidental civilization has evoked violence in every shape and form from its hiding places in matter and in mind, from fire throwers and poison gases to hatred and cruelty, for mutual destruction in this immense conflict. Will these forces obey the call when they are bidden to disband their innumerable legions and to return to their secret abodes? Or will they not as in Russia break out into a hundred wars and revolutions and fall in separate bands on the slight remnant of order and peace which has escaped the great war? No one knows or can tell us.

The Italian people, therefore, has decided that, 
as its strongest strategical frontiers coincide in the Alps with its racial linguistic boundary, to complete its national unity, and at the same time to secure its full independence which Europe and misfortune refused until I9I4 to concede. This -no more and no less-is the meaning of the Italian aspirations to the possession of the Trentino, Trieste, and Istria. By reuniting all her sons in a single State, Italy wishes to make herself safe from future invasion from the mountains of which that of the autumn of 1917 must be the last. She refuses to be threatened by a German power in the Adriatic, which should be a Latin and a Slav sea, because its coasts and the adjoining territories are inhabited only by Slavs and Italians. No one denies that bands of Slovene or Croatian shepherds and peasants, often called in by the Venetian Republic or other possessors of the soil, penetrated from time to time to the southern slopes of the Alps, where they have established permanent dwelling places. But where is the country in which there is not some slight admixture of foreign races and foreign languages along the frontier? These small extraneous groups have the right to demand that their nationality and their language shall be respected; they cannot alter the national characteristics of a region which is fixed by the 
majority of its population, by its history, and by its traditions.

By the time this book is published, the lands desired by Italy will have passed into her possession by force of arms, but Italy does not wish to be suspected of confronting Europe and America with the peremptory argument of force. She wishes the world to be convinced that she has used force in the service of her right to secure national claims as to which the whole nation is agreed. The completion of national unity and the recovery of natural and secure frontiers, however, were not the only reasons for the war which Italy has waged at the cost of such sacrifices. Italy took arms also to prevent the Central Empires from establishing a brutal and tyrannical domination over the whole of Europe. Before I9I4 no impartial observer could have found any trace in Italy of a profound aversion to Germany. There was, on the contrary, a general inclination to overlook her defects in consideration of the high qualities of which she was, or seemed to be, an example. But when Germany took the initiative in starting the conflagration, when she violated the neutrality of Belgium and upset all the laws of war, Italy's admiration was turned to horror. The country felt that it was better to sacrifice what little riches 
it had accumulated in half a century, and to risk the half independence won with so much toil than to stand by and look on at the crime which was being committed against good faith and the rights and liberties of Europe. Sympathy for oppressed Belgium, for France and England who were threatened, were no less potent impulses to intervention than the national claims. Indeed it is quite doubtful whether the latter motives would have been enough without the former to induce Italy to undertake so gigantic and so perilous an enterprise. As events turned out, the sacrifice we made was not in vain. Though the effects of Italian intervention were at first not much felt by the Allies it may be said that the forces of Italy were the salvation of the world at the most terrible crisis of the war, between the collapse of the Russian front and the arrival of American reinforcements in sufficient numbers. Who can say what would have happened if Italy had not intervened, and if, in the spring of 1918 the Central Empires could have turned against the Western Front the seven hundred thousand Austrians which the Italian army kept pinned down in Italy? This is a point which should never be forgotten by any one who wishes to judge justly of what Italy has done. 


\section{To the League of Nations}

Participation in the world war is the last of the sacrifices imposed on Italy by European policy since 1815, after the long subjection to foreign rule, after the grudging and imperfect measure of liberation which was granted to her and the impositions she endured for half a century from the German Empires. And this sacrifice has been so great that it does not seem unreasonable that, after the war, in addition to the satisfaction of her national aspirations she should claim from her richer Allies, France, England, and America some help in rebuilding her shattered fortunes. In proportion to her possessions she had made greater material sacrifices. At the end of the war, she finds all her trade disorganized, her industries upset, and such a burden of public debt that many are asking themselves with anxiety how the people can possibly carry it. Her allies can do much to help her to conquer this difficulty without internal disturbances if they will regard her with intelligent generosity, not forgetting that in the war Italy did all that her strength permitted her to do.

With Italy the greatest victim of the Germanic Empires was Poland. How hardly Europe has expiated not only the wrong done to Italy in 1815 but also the indifference with which the partition 
of the Polish nations was regarded! The fall of Poland has been the true foundation of German greatness. This war has shown that a vast empire like Russia, populated by so many barbarous races with a precarious veneer of civilization, devoured by an insatiable hunger for territory, involved on so many fronts in Europe and Asia, confused by a turbid and unequally distributed culture, was no barrier to Germanism, but in fact an open door to the East. It was known before the war that the Russian Empire was becoming Germanized with extraordinary rapidity in education, in administration, in trade, in industry, and in finance. It is now clear that not even the military power of Russia could be relied on against Germanism. The Empire of the Czar, except in the first few months, fought weakly without energy, without faith, and was upset in the midst of the war by a Revolution the object of which was a peace which was concluded in haste, abandoning the Allies who had made war for Russia's sake. To curb German expansion towards the East we require not an immense half-empty empire like Russia but a compact well-populated national State like the other national States of Europe, France, Italy, or Germany, highly civilized, capable of industrial development, with a dense population and a lim- 


\section{To the League of Nations}

ited territory. This State can be no other than Poland.

Analogous considerations apply to the Austrian nation. We have seen that the power of Germanism rested on two pillars, the German Empire and the alliance of that Empire with Austria-Hungary. The dynasty of the Hapsburgs supported by the German and Magyar aristocracies, secured to Germanism the forces of a polyglot empire of fifty millions of men, all the advantages of geographical position and a broad and solid bridge to the East. The day on which Bohemia, Hungary, and the Southern Slavs become independent, the day on which the Austro-Hungarian army ceases to be a State within a State connected by bonds of personal fidelity to the Emperor, will see the last of the system of military monarchy and Divine Right. Germany will have lost half her strength apart from any other losses she may suffer by the war.

Another necessary reparation is the restoration of Alsace and Lorraine to France. Alsace and Lorraine were the primary reason for this dreadful struggle of the nations. When one looks at them on the map they look so small in comparison with the world's immensity, that it seems impossible that they can have generated so much hatred 
between two powerful nations and disturbed with such terrible consequences the peaceful balance of the whole earth. But whoever knows France and French history understands why she could not forgive or forget the mortal offence inflicted on her by Germany when she was deprived of these provinces which had been French or at any rate Gallicized for so long. France is an equilibrium of opposing forces, a nation neither wholly Northern nor wholly Southern, neither wholly industrial nor wholly agricultural, neither wholly warlike nor wholly pacific. Her life history has been a reconciliation after terrible struggles of these opposing characteristics of climate, race, and tendency. The perennial process of contradiction and reconciliation has produced both her strength and her weakness. In the national equilibrium Alsace and Lorraine play the part of counterpoise to Provence. When they were taken from her, it was not merely a strip of territory that she lost, but a vital element of strength and completeness. There is another reason why the restoration to France of these two provinces will help to reestablish the world balance which has been disturbed for the last fifty years. They are rich in coal and iron. The preponderance acquired by Germany in the metal trades will be diminished 


\section{To the League of Nations}

and this will be a good thing for everybody, because there is no doubt that the prodigious, and indeed monstrous, development of the iron industry was one of the strongest stimulants of German arrogance and ambition, and one of the most profound causes of the incessant growth of militarism.

Nor must little Schleswig be forgotten, the victim which Bismarck chose in order to put to the proof the courage and the foresight of the Great Powers of Europe. The Treaty of Prague provided that the inhabitants of Schleswig could not be annexed to Prussia without their own consent, expressed in a plebiscite. That plebiscite has never been taken. Europe, freed from the German danger, must compel Prussia to keep her promise and allow the Danes of Schleswig to choose freely to what country they wish to belong.

It would, however, be an illusion to believe that the healing of these old wounds inflicted on Justice and Liberty will be enough to secure the peace of Europe. The convulsion has been too vast for that. Let us look about us. The Russian Empire has relapsed into a condition of nebulous incandescence. The Turkish Empire is a corpse awaiting burial. The Austrian Empire has fallen into an abyss in which its trampled and ill-used peoples 
are striving to fight their way through the ruins of the ancient order towards light and air. The second in chronological order of the military empires created by the great earthquake of the French Revolution, it has outlasted all the others, having endured for a hundred and two years. But it is no rash conjecture that another gulf is about to open and swallow the last and the youngest of these Empires-the Empire of Germany. Who can believe that the Germans having laid down their arms, will return to their workshops, their warehouses, their lecture rooms, and take up their labours at the point at which they left off on the first day of August, 1914, as if nothing had happened in the meantime? The German Empire has been mortally wounded by its defeat. The dark forebodings which on January $18,187 \mathrm{I}$, afflicted the old King of Prussia when his companions in arms offered him the Imperial Crown in the old palace of the Kings of France have come to pass. The work of Bismarck is about to be destroyed. It was the work of violence, and it has lasted no longer than all works of violence which deceive mankind by their apparent permanence and crumble in an hour!

Will the German People reconcile themselves easily to the fate of creeping back, hated and dis- 


\section{To the League of Nations}

honoured, into European Society in which for so many years they played the part of proud and tyrannical leaders of Western Civilization? Whatever happens the dynasties, the aristocracy, and the bureaucracy which ruled Germany from I87I till I9I4 have been discredited both at home and abroad, and, even if the exhaustion of the people allows them to rule Germany for a little longer, they have survived themselves.

The crisis which to all appearance it will be impossible for Germanism to escape will have effects much greater than those of the Russian Revolution, even if, as is probable, it does not reach such heights of violence and folly. Before the war the German Government was the only government in Europe which did not tremble before those whom it was its duty to command, which had a power of its own independent of the movement of public opinion, of the play of rival interests, and of the course of events. Further, Germany, in spite of her defects, and partly because of her defects, and because of the energy which is her admitted merit, was a model and a stimulus for all Europe, even if her influence was by no means always good. The Entente Governments in the years before the war were almost all afflicted by the phenomena of old age, red tape, 
incoherence, sluggishness, weakness, uncertainty, and mediocrity of control. This evil had in a greater or a less degree attacked all their organs, parliaments, armies, navies, civil service, and universities alike. The incessant, noisy, often charlatanesque and unscrupulous activities of the German Government undoubtedly had a stimulating effect on the other somewhat weakened governments. Now that the model, good or bad, is discredited and partly destroyed by the crisis which is about to convulse all German institutions, the stimulus will disappear and the psychological equilibrium of Europe will be profoundly disturbed until new models and new stimuli have emerged from among the States which used to imitate Germany. This will require both time and hard work.

Furthermore the successors of the AustroHungarian Empire will be a certain number of new National States. Every lover of liberty will be delighted to greet the appearance in history of these new democracies, but no one will be deceived by the expectation that they can be born full grown. The apprenticeship of a new State is always arduous and tedious, and sometimes tempestuous, and these States are coming into the world in circumstances of extreme difficulty, in 


\section{To the League of Nations}

the midst of a Europe devastated, bled white, convulsed, and impoverished by the war. Everything is destroyed, commercial treaties and treaties of alliance, conventions between State and State relating to the most jealously guarded interests, the public and private law of every single State. The élite of the greater European nations, and more especially its youth who would have been called to govern in ten or fifteen years' time, has been mown down. The Prussian, no less than the English and the French, aristocracy has been decimated. The same is true of the middle class both in France and Germany. The better part of the Russian nation is dispersed or dead. Everywhere the balance of wealth has been upset; vast fortunes have been made without labour by ignorant, incapable, or cowardly persons, while the flower of the population is ruined or has perished in the trenches. The national fortune even of the richest peoples, has been heavily mortgaged in order to meet gigantic war obligations. It is by no means rash to estimate these burdens as amounting to more than half of their total possessions. Finally, during the war there has been revealed to all eyes the double soul-which wishes for power and at the same time for justice - of the State created by the French Revolution 
and by the nineteenth century. In this war all the most generous sentiments which make life dear to men have been exalted; but at the same time the most terrible offensive weapons which the world has ever seen have been brought into action. The States of Western Civilization finally have dared to do what to previous ages would have seemed madness if not a crime, and that is, to arm the masses.

It would assuredly be ridiculous presumption to pretend to predict what is likely to be the future of the world or to indicate to Europe the way to reconstruct a new and better order on the ruins of the old. Yet a few lessons may be learned and a few hints taken without reckless imprudence from the history of Europe subsequent to the French Revolution, which we have narrated above. What is this history if not an alternation of periods of war and peace? Until 1815 incessant war; from I8I 5 to 1848 a long peace; from I848I 870 a new tempest of war; then again peace till 1914. These long intervals of tranquillity prove that the peace of Europe is not a romantic dream of humanitarianism, but a profound need of Western Civilization which is sometimes overborne by other forces as manifested in the recurrence of protracted spells of war. What are these 
forces? The popular explanation is that war is constantly due to the ambition of Courts and dynasties. That explanation was true until I8I5 but from I8I 5 till I848 it was precisely the dynasties which imposed peace and limited the development of militarism everywhere, even in Prussia. Wars and competitive armament recommenced in 1848 just when the liberal bourgeoisie, the industrials, the professional, and intellectual classes, the sections of the community which had nothing to do with the military art, came into power in the State. Even the final and most frenzied rivalry in armaments, which began after 1900, and which culminated in the great war, covered years in which democratic doctrines and democratic parties were everywhere gaining ground. Must we conclude that the responsibility for the unlimited armaments and the great wars of the nineteenth and twentieth centuries lies not with the dynasties and the Courts, but with the middle class parties and the dynasties? It would be absurd.

The truth lies midway. One of the reasons why Europe, though anxious for peace, has for more than a century been unable to sleep without being fully armed and with her sword within reach has nothing to do with either Courts or democracies, but is to be found in the perennial 
conflict for which these respectively stand in this world. For more than a century Europe has been convulsed by a dispute which no argument but only force can settle-who has the right to command? Whom is it the duty of mankind to obey? Shall they obey the dynasties who pretend to have received the sacred mission from God, and the classes and dignitaries who surround and serve them? Or shall they obey the Will of the People as expressed by all the organs which Democracy furnishes, parliaments, elections, a free press, political societies, meetings, and so on? Or again shall they obey both God and the People associated in a sort of mystical and democratic oligarchy? It was this dispute which kindled the wars of the Revolution and the Empire. The banded dynasties of Europe would not have shown so much eagerness to overthrow Napoleon had it not been that his career was the negation of the very principle on which their authority had rested for centuries. The conflict then became more complicated and assumed the double aspect of a fight between the principle of authority and the principle of liberty as well as between the dynastic principle and the principle of nationality. The Holy Alliance united the authoritarian and dynastic principles in the 


\section{To the League of Nations}

struggle with Liberalism and Nationalism, and sought by this alliance to overwhelm the two opposing principles. The Revolution of $\mathbf{I} 848$ broke the Holy Alliance. In some countries, such as France and Italy and, to a certain extent, even Germany, the dynastic principle came to terms with Liberalism and Nationalism. In the AustroHungarian Empire the dynastic principle made some concessions to Liberalism, but continued implacably to combat Nationalism. In Russia the dynasty combated both.

At bottom all the wars and civil wars of Europe in the nineteenth century reveal this conflict, even the world war on which Germany decided in order to save the dynastic principle in the Austrian Empire which was threatened by Nationalism. This conflict, however, as always happens when two principles of government come in conflict, obscured on both sides, and in fact throughout Europe, the sense of law and justice, whether in the institutions and methods of government or in the relations between one State and another. Partisans of the one principle or the other have respected or claimed respect for public law and justice only when this respect could be used as a weapon against the other side. When either hoped to prevail over its opponent, it was ready to 
justify coups d'état, revolution, violation of laws and of treaties, and indeed any violence offered by war or civil war to the principles on which the internal order of the State or the order of the commonwealth of nations was based.

This, I repeat, is the logical explanation of all the struggles the motive of which is the right to command. The ages are full of these struggles, which take different forms. But in all ages when such struggles have raged the human conscience has been subject to the same eclipse and yet the whole world was never rent by such a terrible cataclysm. Why is it that this eclipse of conscience now seems to involve not merely a single State or potentate, but the prosperity and the very existence of the whole of Western Civilization? There seem to be two reasons. The first is that the nineteenth century took such pleasure in the eclipse that it actually made a duty and a glory of it! How disastrous from this point of view was the career of Bismarck! Few men have done more harm than he to Western Civilization. His audacity, his good fortune, the weakness of his adversaries, the confusion into which his insolent triumph threw the map of Europe, the cowardice with which in the end Europe adored this success-all this perverted 


\section{To the League of Nations}

civilization and prepared the most savage and ferocious explosion of violence which history has ever seen.

But to this first reason the second must be added, which is the appalling strength of the instruments of destruction which Western Civilization has at its command. All the older civilizations had observed the rule of the extreme limitation of armaments, according to which the military forces and the military expenditure of any State should be as small as possible and arms the monopoly of a very small minority of the population. After I870 Europe upset this principle and, thanks to conscription, imposed on all Continental States by the French Revolution, thanks to the development of the metal industries and to the growth of riches, it became possible to apply the principle of increasing armaments without limit, and finally to create the monstrous armies of millions which for four years have been massacring each other with such potent and deadly weapons. Thus, while the moral limits were abolished which the principles of international law and the respect for treaties opposed to the exercise of brute force, the material limits which for centuries had been set to the means of such violence were greatly widened. What wonder that, when the 
peaceful fetters which bound it had been broken, violence burst forth and devastated land and sea with a fury of which History had previously seen no example?

This is exactly what makes it a question of life and death for Western Civilization, that these monstrous forces shall be restrained so that they may never break loose again with such homicidal madness. Too many civilizations have perished because they did not know how to check in time the violence which had been let loose to satisfy their passions or to defend their interests. It is clear, therefore, that Europe is confronted with the same task which the Holy Alliance tried to accomplish at the end of the wars of the Revolution and the Empire, namely to clear up and reinvigorate in the obscured and debilitated conscience of Europe the concept of the respect for legitimate authority in the internal relations of every State, and the concept of the respect for the law regulating the relations of one State to another so that thereby future wars and revolutions might be prevented. Though the principles of legitimacy and of international law which it is now expedient to establish are different from those of the Holy Alliance, the means to be used must necessarily be the same-a League of Nations. 
To the Holy Alliance which was a league of European nations formed by the Courts of Europe there must succeed an Alliance of Peoples who are henceforth masters of their own destinies.

The League of Nations has been much discussed during these years of war, but the discussion has been rather confused and a great, far too great, number of different objects have been laid down for it, according to the tendencies of its different advocates. A league - even a league of peopleswhich tries to embrace everything is in danger of accomplishing nothing. Can we in the light of the history of a century attempt to lay down precisely -at all events in principle-what should be the chief principles of a league of the peoples of Europe and America concluded after this terrible war? These principles appear to be three in number. The first is that all the States forming part of the League should undertake to recognize and to deal only with legally constituted governments. Secondly, they should pledge themselves to respect nationality; that is to say the language, the religion, and the culture of every people. Thirdly, they should undertake to reduce armaments to the lowest limits, and to admit the principle of reciprocal inspection. When we have examined these three points our task will be completed. 
The undertaking not to recognize and not to treat with any but lawful governments implies the necessity for a definition of legality accepted by all the contracting parties. What should this definition be? It is very clearly indicated by what has happened. The world war has now annihilated one of the principles of authority which ruled Europe, namely Divine Right. Of the three Empires which represented it the Russian Empire and the Austro-Hungarian Empire are already destroyed. The Germanic Empire is tottering and will either fall or be transformed. No other principle remains, therefore, but that of the Will of the People expressed by means of representative institutions. Henceforth, even in Europe, all parties and all schools of thought will be compelled to recognize, whether they like it or not, that popular suffrage and representative institutions are the fount of lawful authority, for the simple fact is that there is no other. But the Will of the People is a principle of authority which is easily falsified and adulterated by the army or the violence of interests and factions, more especially in Europe where after I 848 it was largely used as an instrumentum regni not only by Napoleon III. but also by the monarchies of Divine Right such as Prussia and Austria. Thus 
the principle will be very weak and the temptation to falsify it by fraud or violence very strong among all parties after the war. The upper classes and the conservative parties of Europe are not prepared, except in France and England, to govern by means of this formula alone, without the support of traditions derived from the formula of Divine Right. Therefore, fearing that Universal Suffrage may get beyond their control, they may repeat the well-known manœuvre of compromising it by excesses when they fail to control it by force or fraud. The extreme parties, on the other hand, who represent, or say they represent, the masses, will have much less respect for the law than they had before the war, because they will feel that authority is weakened, and therefore that it is easier to use force or fraud when they succeed in dominating the vague, fluctuating, and mysterious thing which is the Will of the People.

In order to prevent the States of Europe-and more particularly those which will be emerging from the ruins of the Empires of Divine Rightfrom falling into anarchy, the League of Nations must be in the first place a reciprocal undertaking to see to it that the new principle of authority is loyally maintained by all. Any State which 
abuses the principle or offers violence to it must be excluded from the League and become liable to all the penalties reserved for States which rebel against the federal agreement. The importance of this principle is confirmed by a curious but most manifest proof and one which offers a very sound criterion by which the affairs of Russia may be judged. What is Europe to do with this immense chaos which extends from the Baltic to the Yellow Sea? It is visionary to pretend that the Belligerent Powers can set it in order at the Peace Conference. From a nebula there cannot be re-formed one or more planetary systems each with its sun, its planets and their satellites, without an effort from within. But at any rate, Europe can hasten the process of resolution by declaring that it will not recognize and will not treat with any but a legal government.

When the Russian Revolution broke out it was at once compared with the French Revolution. This was an error, because the Russian Revolution resembled not the French Revolution of 1789 but the Paris Revolution of $\mathbf{I} 848$. Like the latter it began with an abdication which was intended to preserve the power of the reigning family, but was carried out too late and was overwhelmed by the revolutionary and republican movement 
which upset the dynasty and entrusted the State to a Provisional Government. In France, as in Russia, the Provisional Government proposed to summon an assembly elected by Universal Suffrage to arrange the new State. But in France, as in Russia, the extreme parties, particularly the Socialists, at once began to accuse the Provisional Government of betraying the Republic, and to demand social reforms which upset the balance of Society. Finally, in France, as in Russia, these factions rose in armed rebellion against Universal Suffrage. At this point the difference begins. While in Paris the revolt against Universal Suffrage was overcome during the fighting of June, the Maximalist movement was victorious at Petrograd. This is the very reason why the Allies who have vanquished the Central Empires should declare that they will recognize no Russian Government which is not formed by a Constituent Assembly debating after being regularly elected and convoked. The faction which now rules over part of Russia has intruded itself into power by acts of violence, and therefore has no title to authority but force. Europe cannot recognize it.

This principle also raises the tremendous question whether, and if so when, a more powerful 
State has the right to control the affairs of another and a weaker State-the so-called rights of civilization over savages. In the circle of European and American civilization, comprising all the States which have accepted the Will of the People expressed through representative institutions as the fount of authority, and which will therefore form part of the League of Nations, incapacity to work representative institutions peacefully will be the only justification for foreign intervention, single or collective. Among peoples which use different principles of authority, the question is more difficult. It is enough for the moment to forecast that, if forcible intervention in such cases does become necessary, its motives will be higher than the old idea of etwas erwerben.

The second principle which the League of Nations must regard as a cornerstone of the new European edifice, is the principle of nationality, or, in other words, the right of a people to be governed by men of its own race, language, culture, and religion, and, when this is impossible, the right to have its language, culture, and religion respected, however different these may be from those of the majority, and not to be compelled to change them against its will. Nations 


\section{To the League of Nations}

desire peace or war not merely because they are naturally pacific or warlike, but according to the spirit which moves them and the interests or passions which prevail at a given moment. The fall of two Empires like Russia and AustriaHungary under which so many nations lived together in the bonds of fidelity to a single dynasty may well multiply and not diminish occasions of war if the national States which will take the place of these Empires begin to quarrel bitterly over the delimitation of their frontiers, for the possession of a river or a range of mountains, a mineral region or a position of strategical value. The boundaries of language and nationality are never very clear, and how many are the interests which may confuse and embitter national conflicts in these debatable lands! Without some superior authority to check and regulate these conflicts with justice the reconstitution of Europe in accordance with the principle of Nationality might create all over the continent a large number of little Alsace-Lorraines. The questions which have already arisen between Poland and the Ukraine on the subject of their future boundaries, before even the States themselves have come into being, may give some idea of the danger and the difficulty. Nor is it possi- 
ble that all men speaking the same language shall be placed under their national government, for there will always be small and dispersed nuclei for ever completely enclosed in foreign territory. Even after Europe has been reorganized on the basis of the principle of nationality there will be Slavs in Italian territory, and Italians and Germans in Slav territory. What wars may not germinate from these exceptions to the principle of nationality if they are not tempered by a scrupulous respect for all the rights of national minorities!

It is, in fact, necessary to lay down respect for nationality as a fundamental principle of public law, and consequently to forbid any violence to this principle involving the dismemberment of a nation on any ground whatsoever, whether strategic, economic, or political. The principle must be regarded as overriding every interest. Moreover the policy of forced denationalizationalso a German invention-must be rigidly proscribed as an act of illegal warfare. It is only by the resolute and coherent application of these two propositions that it will be possible to find any way out of the inextricable tangle of the Balkan problem. In the Balkan peninsula nationalities are so involved with each other that it is difficult 
to say whether some lands are Bulgarian, Serbian, Albanian, or Greek. This is the case in Macedonia. If force is applied to the problem, we cannot expect any solution until, after a century of warfare, all the combatants have perished and the country in dispute has been destroyed. Only a reasonable and just agreement, firmly and coherently applied to the four Balkan peoples, can cut the knot without producing new catastrophes. We must review the Treaty of Bucharest, which was imposed by the sword, and recognize Bulgaria's rights in Macedonia so far as they are just. We must not take the opportunity offered by the rearrangement of the peninsula to inflict punishment, however well merited. We must insist on the four Balkan peoples forming a federation with mutual obligations not to offer violence to populations of different nationalities, and we must take care that they are sparingly supplied with arms. The revision of the Treaty of Bucharest should be easy now that Serbia and Greece are to be increased by so much new territory that is entirely Serbian and Greek. Thus, little by little, the small foreign groups which remain in every State will become spontaneously denationalized and the Balkan Peninsula, the focus of so many wars, 
will be pacified under the care and guidance of the League of Nations.

There remains the third and last principle, the limitation of armaments. I have said limitation of armaments, and not disarmament as many do; because the word disarmament is either improperly used to mean limitation of armaments or implies an error of substance. No European State, and no State in this world, can entirely disarm, because force is, to a certain extent, a necessary element in its life, good order, and wellbeing. But no State is obliged to develop its force to the utmost at the risk of perishing from a congestion of energy. Very powerful States and flourishing civilizations have been able to subsist with limited military forces. Why should not the States of Europe and Western Civilization continue to flourish in the same way? It is difficult to predict whether the war which is now drawing to a close is indeed to be the last of all wars. It certainly must be if Western Civilization is not to be destroyed utterly. In order that it shall be the last, we must limit the instruments of destruction which have grown too much in number and in power. This, as many think, is not beyond the wit of man to accomplish; it is possible, and even easy, if the 


\section{To the League of Nations}

peoples of Europe and America firmly and sincerely wish it.

The century of history which we have narrated shows clearly what are the three most effective means of limiting armaments. The first is the registration of all armament factories. Has not the monstrous development of European militarism been due, at any rate in part, to the free range of industry which, excited by a passion for enormous gains, has multiplied inventions of new and powerful instruments of war. The second remedy, which is still more drastic, is the universal abolition of conscription and a return to professional armies. Conscription alone-the expedient for increasing numbers-has made possible the creation of the overgrown armies which have fought this interminable and most murderous war. The day on which governments will be able to rely only on voluntary enlistments will again-and for obvious reasons-see the reduction of armies to modest proportions. Europe will also have the advantage of being able to revive and preserve in these small armies the true and sane principles of the art of war instead of the monstrous falsification of them which the German victories of 1866 and 1870 foisted on the world. The third and last remedy 
is mutual inspection and control of armaments. A League of Nations will be senseless if it does not accept the principle that the number, the organization, and the purpose of military forces are not matters of which each State, as part of its sovereignty, is to be the absolute judge, but questions of common interest to the League of which they form part.

Are these ideas and proposals dreams which will perish in the coming whirlwind of events? Or do they contain some possibilities of transformation which will become the actualities of tomorrow? We shall see. But if anyone says that such an order of things has never been and consequently can never be again, the answer is that on the contrary Europe has known an example, though on a smaller scale, of reciprocal control among a body of States, minutely organized to maintain peace and internal order. This was the Germanic Confederation set up in 1815 by the Congress of Vienna which Bismarck, the evil genius of the new Europe, hated and destroyed in I866. Will Europe as a whole after such a terrible experience, when it is a question of saving Western Civilization from a disaster the consequences of which may last for centuries, fail to achieve what the Germans did before they 


\section{To the League of Nations 28I}

were tempted by the Devil and sold their souls? However this may be, the Americans, who have already saved Europe from German domination by intervening when Russia abandoned the common cause, can do much to help Europe to save itself from the dangers which await it by using all the authority America so justly enjoys to encourage and impel the old continent to follow this path resolutely. They will by so doing render a great service to Europe, and to America as well. Western Civilization is a grandiose Gothic vault, soaring sublime towards the sky. One of its arches is Europe, the other America. If either arch is broken, the other will be endangered. 



\section{The Chaos in Europe}

By

\section{Frederick Moore}

Author of "The Balkan Trail," "The Passing of Morocco," etc.

With an Introduction by

Charles W. Eliot, LL.D.

President Emeritus, Harvard University

12. Folding Map in Color. \$1.50 net By mail, $\$ 1.65$

A Consideration of the Political Destruction that has taken place in Russia and Elsewhere and of the International Policies of America.

The author has had a rare experience as a correspondent, qualifying him to a remarkable degree to describe the present military and political situation. His suggestions referring to the future foreign policy of the United States merit the careful attention of leaders of opinion.

\section{G. P. Putnam's Sons}

New York

London 


\title{
The World War \\ And Its Consequences
}

By

William Herbert Hobbs

\author{
With an Introduction by \\ Theodore Roosevelt
}

Cr. $8^{\circ}$. \$2.50 net. By mail, \$2.70

Theodore Roosevelt said, after a careful reading of the Manuscript: "It is the literal truth, that if I could choose only one book to be put in the hand of every man and woman in the United States, I would choose the book of Professor Hobbs."

\section{G. P. Putnam's Sons}

New York

London 


\section{The Vandal of Europe}

By Wilhelm Mühlon

I2 $2^{\circ} \$$ I.5O net. By mail, $\$ 1.65$

Herr Mühlon, formerly one of the important directors of the great Krupp works, and intimately connected with the ruling group of the German Empire, is now an exile. Why? Because he became sickened by the ruthless ambition and barbarous methods of the military caste that plunged the world into the present terrible warfare.

This book is Muihlon's diary, kept during the first few months of the war, when he was still a director of Krupp's.

On August 30, 1914, he wrote: "It is only today that I have at last learned to know my compatriots." A few days later: "The German press is a shameful liar." On November roth: "I have received authentic information from the front that the Kaiser declared before an assembly of officers that Germany had enough prisoners, and that henceforth no more prisoners must be taken alive." This all-important volume merits world-wide circulation.

\section{G. P. Putnam's Sons}

New York

London 


\title{
The \\ Guilt of Germany
}

For the War of German Aggression

\author{
By \\ Prince Karl Lichnowsky \\ Preface by \\ Viscount Bryce
}

12. Price, $75 \mathrm{c}$, net, By mail, $85 \mathrm{c}$,

This volume contains Prince Lichnowsky's famous "memorandum" in which he fastens the guilt for propagating the world war, on Germany-unhesitatingly proclaims it the war of German Aggression. The author was German Ambassador to England before hostilities broke out, and he upholds England as blameless, and hails Earl Grey as an apostle of Peace. Von Jagow's reply to the "memorandum" is included.

\section{G. P. Putnam's Sons}

New York

London 


D Ferrero, Guglielmo

363 Problems of peace

.14

\section{PLEASE DO NOT REMOVE}

CARDS OR SLIPS FROM THIS POCKET

\section{UNIVERSITY OF TORONTO LIBRARY}




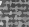

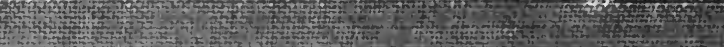

2.5.5.

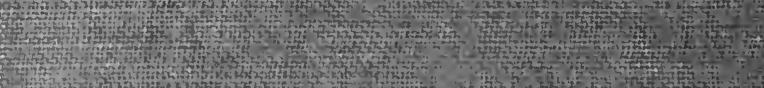
(3)

(n)

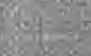

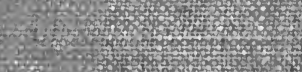

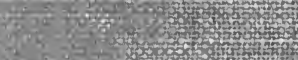

Whth

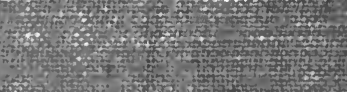

on

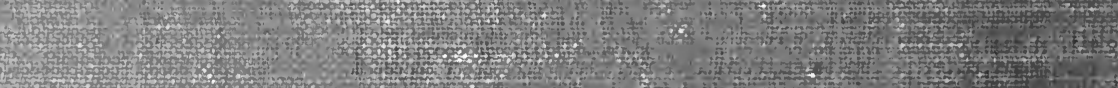
270 .

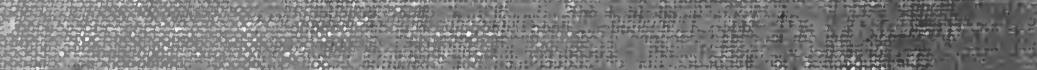
(1) H.

,

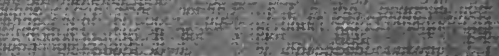

